\title{
COFIRING OF BIOMASS AT THE UNIVERSITY OF NORTH DAKOTA
}

Final Report

(for the period June 15, 2000, to December 31, 2001)

Prepared for:

AAD Document Control, MS 921-107

National Energy Technology Laboratory

U.S. Department of Energy

PO Box 10940

Pittsburgh, PA 15236

DOE Agreement No. DE-FC26-00NT40807; UND Fund 4653

Performance Monitor: Sean Plasynski

Prepared by:

Phillip N. Hutton

Energy \& Environmental Research Center

University of North Dakota

PO Box 9018

Grand Forks, ND 58202-9018

2002-EERC-01-01

January 2002 


\section{DOE DISCLAIMER}

This report was prepared as an account of work sponsored by an agency of the United States Government. Neither the United States Government, nor any agency thereof, nor any of their employees makes any warranty, express or implied, or assumes any legal liability or responsibility for the accuracy, completeness, or usefulness of any information, apparatus, product, or process disclosed or represents that its use would not infringe privately owned rights. Reference herein to any specific commercial product, process, or service by trade name, trademark, manufacturer, or otherwise does not necessarily constitute or imply its endorsement, recommendation, or favoring by the United States Government or any agency thereof. The views and opinions of authors expressed herein do not necessarily state or reflect those of the United States Government or any agency thereof.

This report is available to the public from the National Technical Information Service, U.S. Department of Commerce, 5285 Port Royal Road, Springfield, VA 22161; phone orders accepted at (703) 487-4650.

\section{ACKNOWLEDGMENT}

This report was prepared with the support of the U.S. Department of Energy (DOE) National Energy Technology Laboratory Cooperative Agreement No. DE-FC26-00NT40807. However, any opinions, findings, conclusions, or recommendations expressed herein are those of the authors(s) and do not necessarily reflect the views of DOE.

\section{EERC DISCLAIMER}

LEGAL NOTICE This research report was prepared by the Energy \& Environmental Research Center (EERC), an agency of the University of North Dakota, as an account of work sponsored by DOE and Minnesota Power, Inc. Because of the research nature of the work performed, neither the EERC nor any of its employees makes any warranty, express or implied, or assumes any legal liability or responsibility for the accuracy, completeness, or usefulness of any information, apparatus, product, or process disclosed, or represents that its use would not infringe privately owned rights. Reference herein to any specific commercial product, process, or service by trade name, trademark, manufacturer, or otherwise does not necessarily constitute or imply its endorsement or recommendation by the EERC. 


\section{TABLE OF CONTENTS}

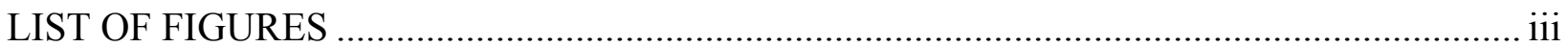

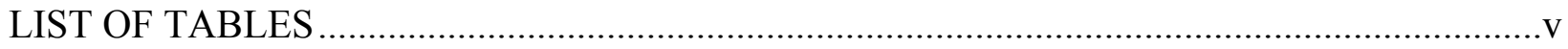

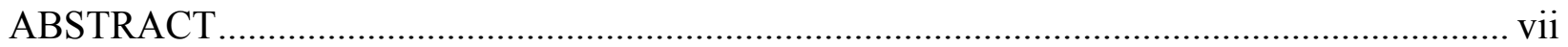

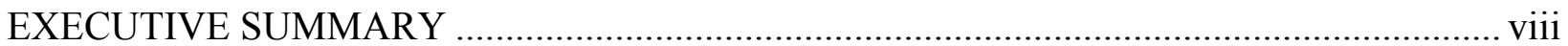

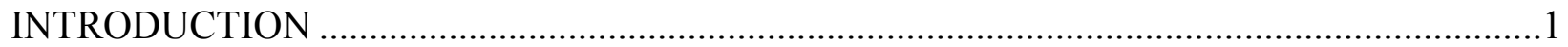

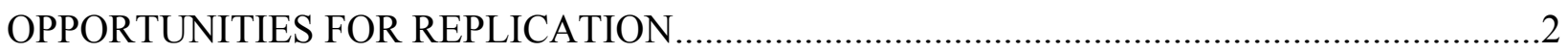

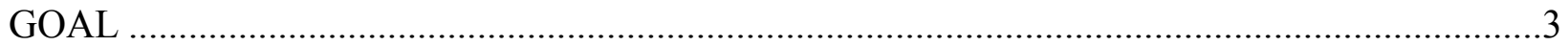

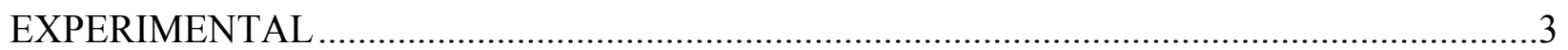

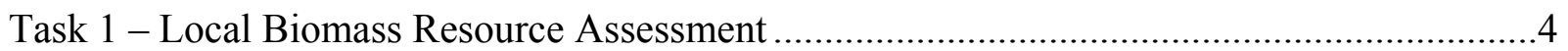

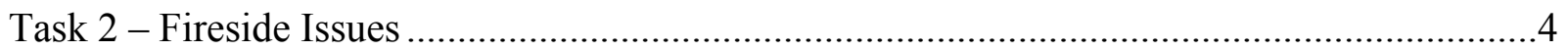

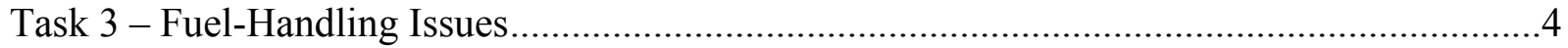

Task 4 - Engineering Economic Analysis ...........................................................................

Task 5 - Energy Production Assessment.................................................................................

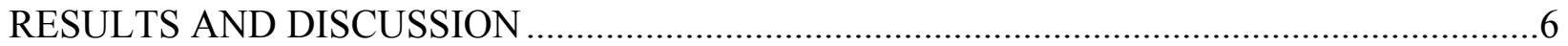

Task 1 - Local Biomass Resource Assessment .....................................................................

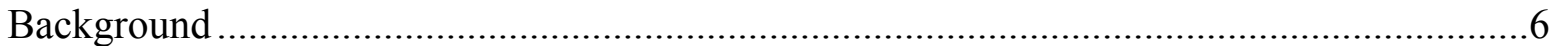

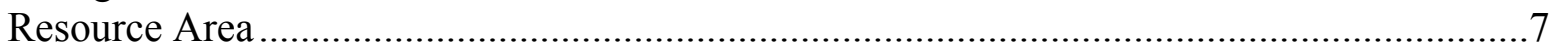

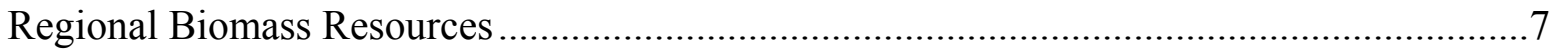

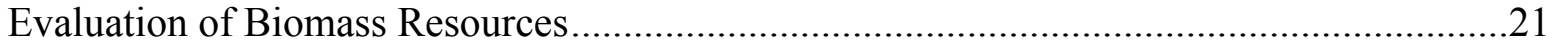

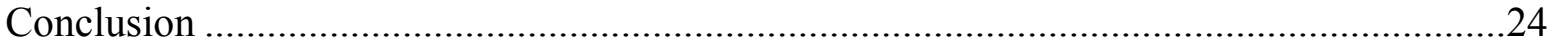

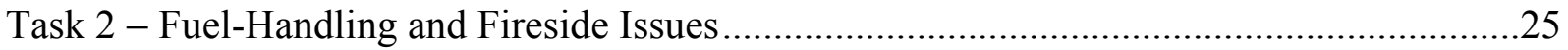

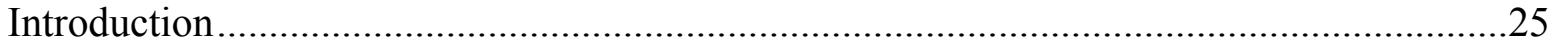

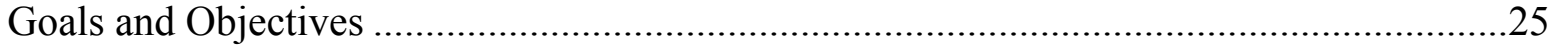

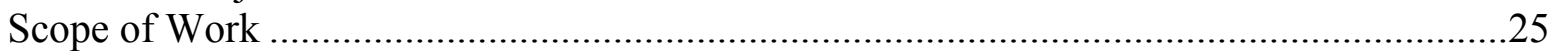

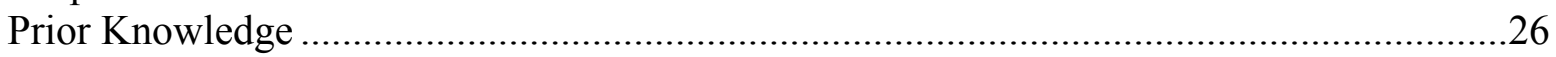

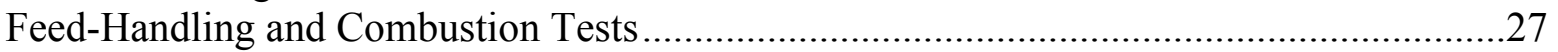

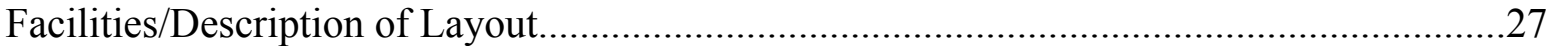

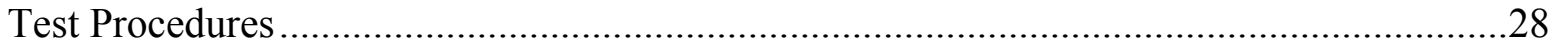

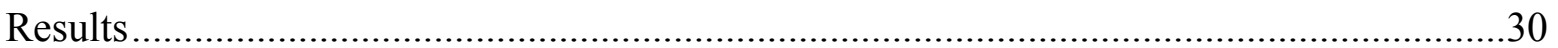

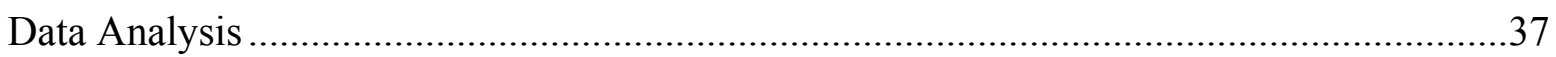

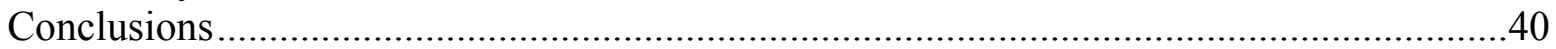

Summary Conclusions ……………………………................................................ 


\section{TABLE OF CONTENTS (continued)}

Task 3 - Fuel-Handling Issues ......................................................................................4

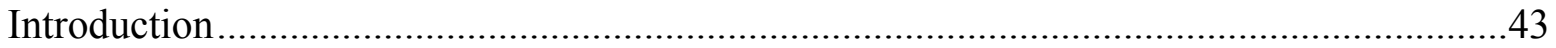

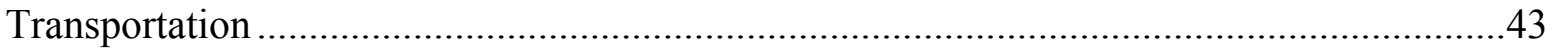

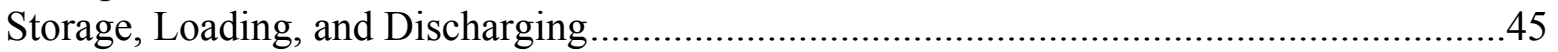

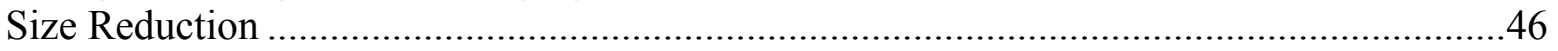

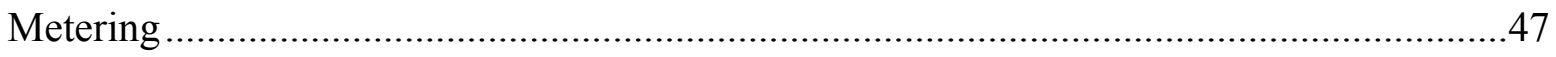

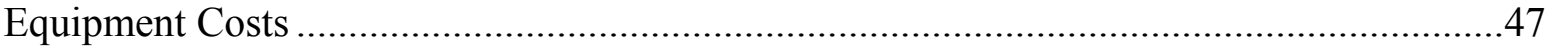

Task 4 - Engineering Economic Analyses .................................................................54

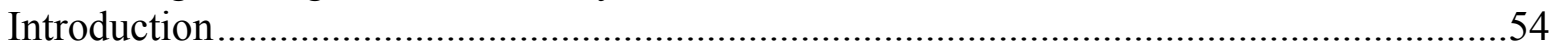

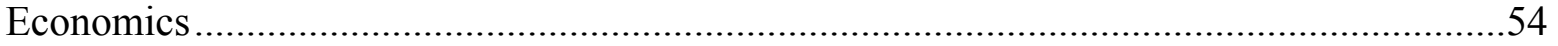

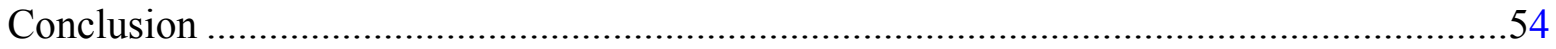

Task 5 - Energy Production Assessment.........................................................................57

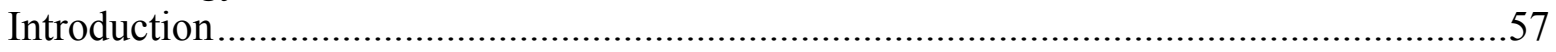

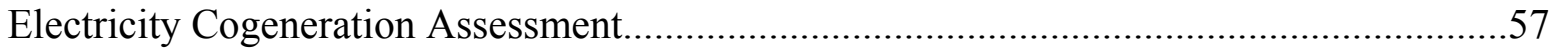

Changes in Boiler Emissions and Their Effect on Permitting .......................................57

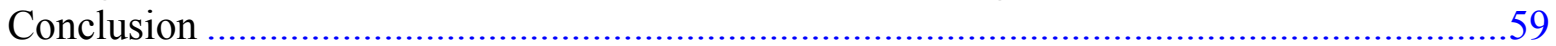

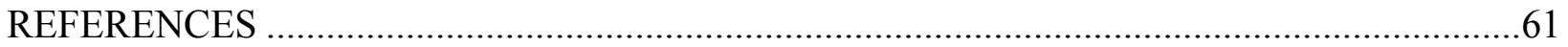

RESOURCE ASSESSMENT ........................................................................ Appendix A 


\section{LIST OF FIGURES}

Figure 1-1. Counties within 100 miles of Grand Forks ...............................................................

Figure 1-2. Distribution of cattle in counties surrounding Grand Forks......................................13

Figure 1-3. Distribution of sheep in counties surrounding Grand Forks ......................................14

Figure 1-4. Distribution of hogs in counties surrounding Grand Forks........................................14

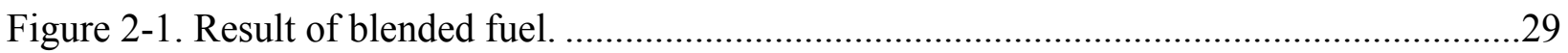

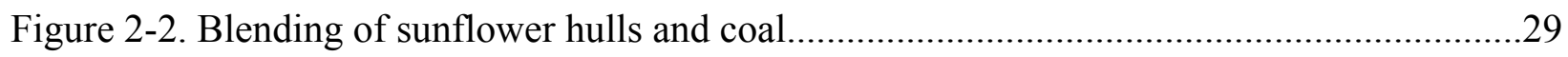

Figure 2-3. Example of loading fuel into the system and potential dust issues............................32

Figure 2-4. Example of segregation issue at stoker inlet on Boiler 3 ..........................................32

Figure 2-5. Cold test Boiler 3 - hulls at stoker end of grate, coal at opposite end..........................34

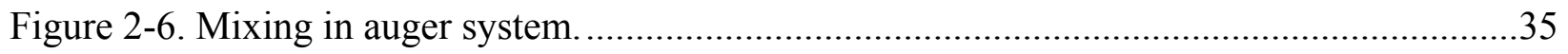

Figure 2-7. Fuel feed at discharge of bunker on Boiler 5 prior to stokers........................................36

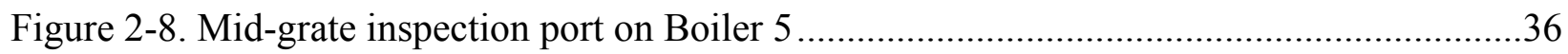

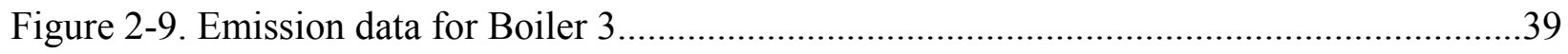

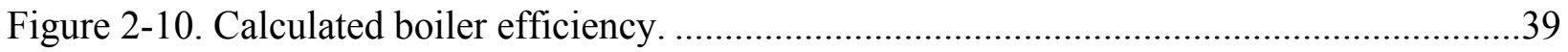

Figure 2-11. Baghouse particle-size distribution. ...................................................................

Figure 2-12. Performance data on Boiler 5 for baseline coal and sunflower-coal mixed feed.....41

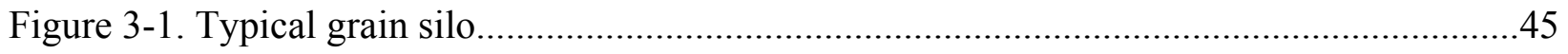

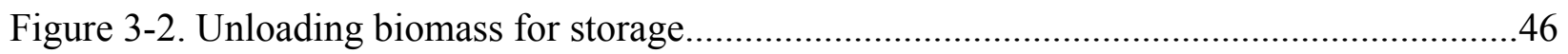

Figure 3-3. Conceptual design of biomass feed system...........................................................48

Figure 3-4. Proposed layout configuration for Option 2.......................................................51

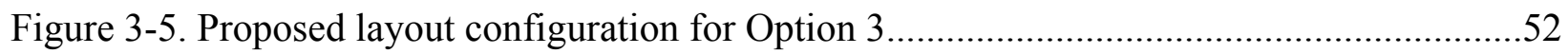

Figure 3-6. Proposed layout configuration for Option 4..........................................................53 


\section{LIST OF FIGURES (continued)}

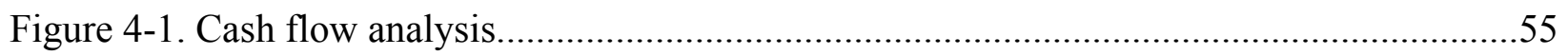

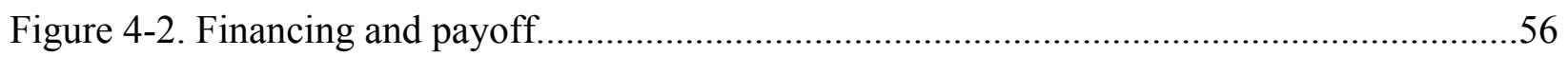

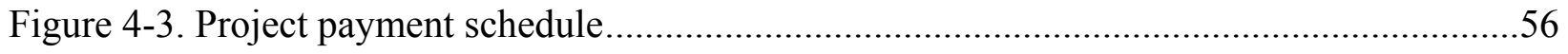




\section{LIST OF TABLES}

Table 1-1. Types of Biomass Available in Grand Forks Area.......................................................

Table 1-2. Agricultural Wastes in the Grand Forks Area ….........................................................

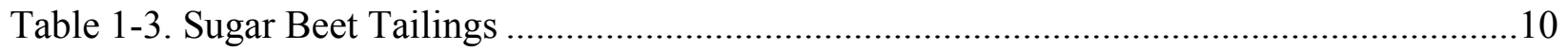

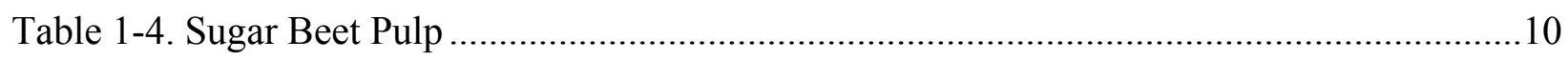

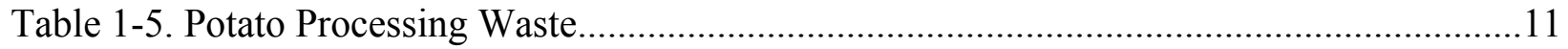

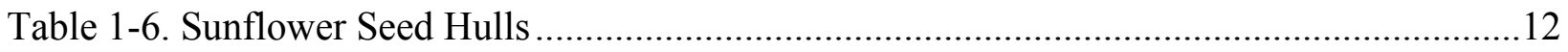

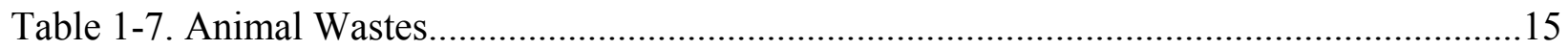

Table 1-8. Average Collectible Crop Residuals in North Dakota ..................................................16

Table 1-9. Fertilizer Value of Crop Residues per Ton....................................................................16

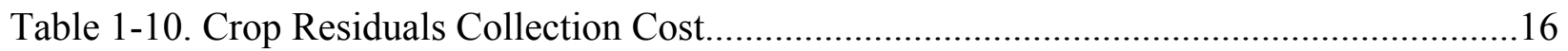

Table 1-11. Average Cost of the Crop Residues per ton .........................................................17

Table 1-12. City of Grand Forks Annual Urban Waste Production ...........................................17

Table 1-13. Industrial Wood and Paper Wastes............................................................................18

Table 1-14. Cost/ton of Brush for Various Time Periods ...........................................................18

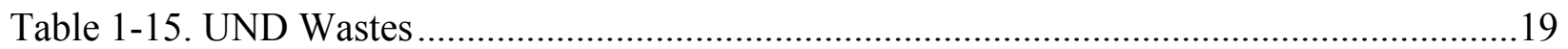

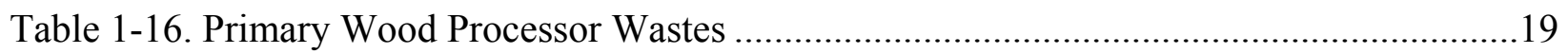

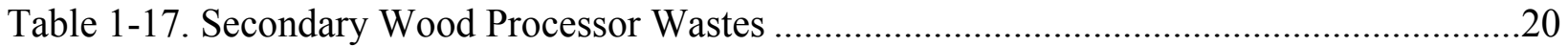

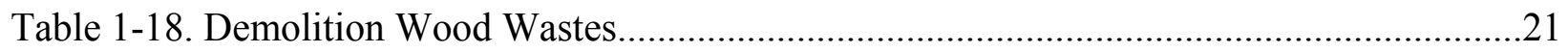

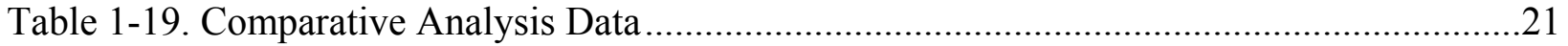

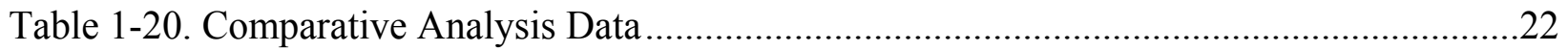

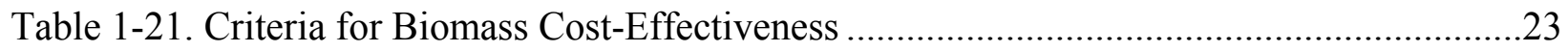

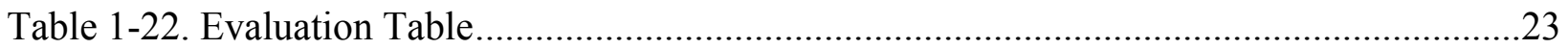




\section{LIST OF TABLES (continued)}

Table 2-1. The Input and Output Parameters Monitored for the Combustion Runs.....................31

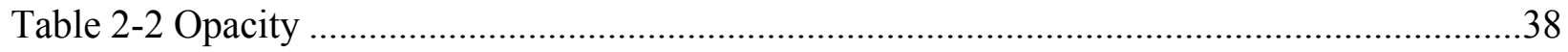

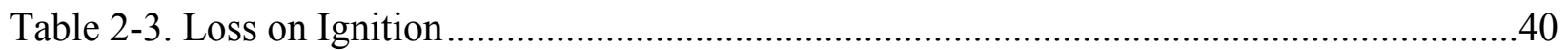

Table 3-1. Cost of Purchasing a Truck and Full-Time Driver ................................................44

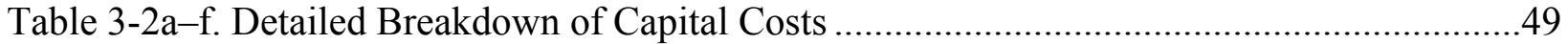




\title{
COFIRING OF BIOMASS AT THE UNIVERSITY OF NORTH DAKOTA
}

\begin{abstract}
A project funded by the U.S. Department of Energy's National Energy Technology Laboratory was completed by the Energy \& Environmental Research Center to explore the potential for cofiring biomass at the University of North Dakota (UND). The results demonstrate how $25 \%$ sunflower hulls can be cofired with subbituminous coal and provide a $20 \%$ return on investment or 5-year payback for the modifications required to enable firing biomass.
\end{abstract}

Significant outcomes of the study are as follows.

A complete resource assessment presented all biomass options to UND within a 100-mile radius. Among the most promising options in order of preference were sunflower hulls, wood residues, and turkey manure. The firing of up to $28 \%$ sunflower hulls by weight was completed at the university's steam plant to identify plant modifications that would be necessary to enable cofiring sunflower hulls. The results indicated investments in a new equipment could be less than $\$ 408,711$. Data collected from test burns, which were not optimized for biomass firing, resulted in a $15 \%$ reduction in sulfur and $\mathrm{NO}_{\mathrm{x}}$ emissions, no increase in opacity, and slightly better boiler efficiency. Fouling and clinkering potential were not evaluated; however, no noticeable detrimental effects occurred during testing.

As a result of this study, UND has the potential to achieve a cost savings of approximately $\$ 100,000$ per year from a $\$ 1,500,000$ annual fossil fuel budget by implementing the cofiring of $25 \%$ sunflower hulls. 


\section{COFIRING OF BIOMASS AT THE UNIVERSITY OF NORTH DAKOTA}

\section{EXECUTIVE SUMMARY}

Through funding on behalf of the U.S. Department of Energy Biomass Cofiring Program and cost share from the University of North Dakota (UND) and the North Dakota Division of Community Services, the Energy \& Environmental Research Center has completed an economic and technical feasibility study on the cofiring of biomass with coal for UND's district steam facility. The results of the study demonstrate how the cofiring of $25 \%$ sunflower hulls with subbituminous coal is an economically attractive option for UND. The university could achieve a $20 \%$ return on investment for a 5 -year payback for the purchase of equipment that enables the cofiring of sunflower hulls, sawdust, or similarly sized biomass fuels.

Sunflower hulls are the most promising biomass fuel based on quantity, cost (approximately $\$ 15 /$ ton), quality, availability, and reliability. Actual firing of up to $28 \%$ sunflower hulls in the UND steam plant facility boilers proved that the total investment in equipment could be minimized to $\$ 408,711$. This includes the purchase of a truck, a separate biomass storage silo with reducing equipment, and a rate-controlled delivery system. Feed tests concluded that a separate mixing system and hardware modifications to the existing feed system and boiler would not be required. Combustion tests indicated approximately a $15 \%$ reduction in sulfur and $\mathrm{NO}_{\mathrm{x}}$ emissions, with a $0 \%$ increase in opacity. Operation of the boiler during cofiring should be adjusted by increasing overfire air to $40 \%$ and slowing the grate speed to maintain a greater ash layer.

The University was very pleased with the results of this study and is currently pursuing funding to complete long-term combustion tests for cofired sunflower hulls. Many of the suggestions presented in this study may eventually be implemented by the University to achieve a cost savings of approximately $\$ 100,000$ per year from a $\$ 1.5$ million annual fossil fuel budget. 


\section{COFIRING OF BIOMASS AT THE UNIVERSITY OF NORTH DAKOTA}

\section{INTRODUCTION}

The University of North Dakota (UND), located in Grand Forks, North Dakota, operates a steam facility that currently fires 50,000 tons/year of subbituminous coal, providing $75,000 \mathrm{Btu} / \mathrm{hr}$ of $130 \mathrm{psig}$ saturated steam to the campus. UND is currently considering switching fuel from coal to a blend of coal and biomass. Switching from coal to a blend of coal and biomass typically has a beneficial impact with regard to stack emissions. Most biomass sources are low in sulfur and result in substantially lower $\mathrm{SO}_{2}$ emissions for the same fuel input. Biomass typically has lower ash content, resulting in lower amounts of uncontrolled particulate emissions; however, the particulates generated from burning biomass are typically finer than coal ash and may or may not lead to lower stack emissions. When burned wet, biomass will also reduce flame temperatures during combustion and can produce lower levels of $\mathrm{NO}_{\mathrm{x}}$. Biomass being considered for cofiring is sunflower hulls, turkey manure, sawdust, and wood waste.

The characteristics of biomass power systems make it difficult for biomass systems to compete as a source of energy. The capital costs associated with biomass energy production are higher than conventional technologies, due in part to the extra emphasis that must be placed on fuel delivery, storage and handling systems and the higher costs associated because of the reverse economies of scale for small systems. In addition to high capital costs, biomass systems typically have high fuel costs and high operating and maintenance costs. The low efficiencies of these systems also play an important role in keeping costs high.

Direct combustion of biomass for energy production was initially viewed as a suitable replacement for fossil fuels. However, ash-related problems, including slagging, agglomeration, corrosion, and erosion, can cause frequent unscheduled shutdowns, having negative implications on availability and reliability. In addition, fouling of heat exchange surfaces coupled with the high moisture in the fuel reduces system efficiency. The variable nature of the quality of biomass fuel also impacts the reliability and availability of biomass systems.

The current nature of the deregulated power industry also has a significant impact on the introduction of new biomass power systems. The restructuring of the electricity market has shifted the focus from diversification of electricity generating technologies to a least-cost approach to generating electricity. Deregulation-related barriers to the biomass industry include market prices, long-term capital investment risks, and inadequacies in alternative energy subsidies. The ability to command high prices for biomass-based power that was present under PURPA (Public Utility Regulatory Policy Act) and other legislative actions has virtually disappeared, forcing biomass power to compete directly with other energy sources. In addition, the current transmission and dispatch market has not been developed to the point where a small, independent power producer could effectively negotiate a contract and cost-effectively sell power to the grid. Concerns over power quality also factor into the reluctance of the transmission companies to deal with small electricity producers.

Another barrier to the biomass industry is the reluctance of the financial community to invest in what it perceives as a risky business venture. The uncertainty of power purchase agreements and the recent closing of many unprofitable biomass plants are key issues for 
investors. The uncertainty of fuel supply and the more stringent environmental regulations are also deterrents to potential financial investors.

Prudent selection of niche markets will allow biomass to penetrate the market currently held by fossil fuels. The Energy \& Environmental Research Center (EERC) has completed a feasibility study evaluating the cofiring of biomass fuels with a low-rank coal at UND. Cofiring the biomass with coal can minimize the high capital costs associated with biomass production. Low-rank coal-fired furnaces are designed to convert high moisture, low heating value fuel into energy while dealing with a variety of ash-related problems. While some capital expenditures will be required for the biomass feed systems, other expensive boiler modifications are unnecessary when biomass is fired in a low-rank coal-designed stoker-fired furnace. Boiler maintenance costs are likely reduced by the addition of biomass, because of the lower ash content of the biomass. System efficiencies will be similar for the biomass and low-rank coal. Therefore, while designing a system to fire biomass alone results in a high cost of electricity, cofiring biomass with low-rank coal in a stoker will not result in any significant cost increases. In fact, if the biomass fuels are low in cost, the savings in fuel cost will more than offset the capital costs associated with the installation of a biomass fuel-feed system.

Biomass also has important implications for the environment. Unlike low-rank coals, which can have a sulfur content in the $0.75 \%-2 \%$ range, biomass contains virtually no sulfur. Biomass thus offers benefits by reducing $\mathrm{SO}_{2}$ emissions, which are tied to acid rain. For most applications using a fuel such as North Dakota lignite, cofiring as little as $20 \%$ biomass will make the fuel sulfur-compliant. This makes the use of low-rank coal feasible in smaller applications that cannot afford to add scrubbers. The fuel-bound nitrogen in biomass is also significantly lower than in coal, which may help reduce emissions of $\mathrm{NO}_{\mathrm{x}}$, which contributes to urban ozone pollution.

Trees and other plants remove carbon dioxide from the air during growth. Thus biomass combustion recycles atmospheric carbon, rather than contributing additional carbon, as occurs with combustion of fossil fuels. As a result, the use of biomass in substitution for fossil fuels offers an important option for reducing emissions of greenhouse gases, which contribute to global warming. In addition, the significant amount of the greenhouse gas methane that is generated from landfills can be eliminated by combusting that material.

\section{OPPORTUNITIES FOR REPLICATION}

Biomass cofiring at UND is a technology that has numerous applications that can augment sustainability and replication of this type of bioenergy use (DOE, 2000). There are 5800 district energy systems in the United States producing 1.1 quadrillion Btu. Of this, 118 trillion Btu are coal-fired. The EERC estimates from these data that there are at least 622 coal-fired state and federal facilities across the United States, including correctional institutions, universities, and federal installations that could have similar biomass-cofiring technologies implemented. State and federal institutions are generally in a better position than private industry for becoming aware of federal and state energy efficiency grant monies and implementing biomass-cofiring capabilities. State and federal institutions that take the lead in implementing bioenergy technologies provide a compelling demonstration model for private industry to follow. There are approximately $95,000,000$ short tons of coal consumed by other industrial and manufacturing 
stoker facilities in the United States. Many of these companies would look to incorporating renewable energy as part of their steam and power generation and may view having extra energy to sell on the grid as a means to pay for this renewable energy upgrade.

Many large utility boilers that fire coal have major problems convincing their stakeholders that biomass energy is sustainable and economically justified. Even when a biomass resource is available in a sufficient amount, the low specific volumetric energy density and resulting high transport volume renders biomass unattractive for incorporation in the fuel diet of a large coalfired utility boiler. The smaller size and versatility of these smaller stoker-type furnaces is a positive reinforcement for sustainable biomass energy production.

Low-cost technological options for incorporating biomass into larger-scale centralized electric power utility boilers are not readily available. Most coal-fired boilers are pulverized fuel systems, and biomass introduction requires costly fuel processing and specially designed feed systems. The stoker-fired system for cofiring biomass and low-rank coal being proposed herein is a form of technology that could be implemented in larger boilers, having performed much of the technological design and demonstration. In Austria, an integrated cocombustion grate for biomass was installed in a 124-MW wall-fired pulverized coal unit (Mory and Tauschitz, 1999) The grate feed system was installed at the bottom of the boiler below the wall burners for effective fuel incorporation with no need for high maintenance fuel preparation and processing or complicated duct systems with this design. Stoker or grate-firing concepts for incorporating biomass into existing boilers could show lower design, equipment fabrication or installation, and fuel preparation or processing costs.

Electric utilities could also be impacted by becoming more aware of biomass opportunities for cofiring arrangements. Midwestern utilities are preparing for possible deregulation of the utility industry within a few years, and marketing incentives, such as providing "green" power service derived from biomass fuels, are very attractive. More information dissemination is needed between U.S. Department of Energy programs and midwestern utilities on biomass fuel types, transportation issues, and technological hurdles with respect to biomass performance in conventional coal boilers. Many of these issues will be addressed by this project.

\section{GOAL}

The goal of this feasibility study by the EERC is to provide a comprehensive assessment of the potential for cofiring biomass at UND. A secondary goal of this feasibility study is to provide a good case study for other university district heating systems.

\section{EXPERIMENTAL}

The scope of the work entails a series of tasks designed to analyze a crucial stage in the development of an economically viable cofiring system. Throughout the study, the primary focus was to determine the most economically viable options available. In this respect, this study is different from many others. The typical approach to developing a cofiring system in the past was to decide on a readily available biomass resource and then address the technical issues required to convert a coal-fired plant into a cofiring system. The final issue that was addressed was 
system and operational costs. Most cofiring systems relied heavily upon the environmental benefits and the public perception of a "green" technology to justify the investment into a cofiring system. The argument was that these benefits outweighed the additional costs and burden of operating a cofiring system. This assessment is approaching the problem with a much greater emphasis on the economics of developing a workable and sustainable cofiring system. In essence, the primary objective of this study is to justify the investment in a cofiring system by showing the steam plant facility that there is money to be saved. A secondary objective is to minimize the additional workload necessary to operate a cofiring system. The environmental benefits are supplemental to the economic benefits. If these objectives are met, then we feel that a viable and sustainable cofiring system can be implemented at the UND steam plant facility.

\section{Task 1 - Local Biomass Resource Assessment}

Task 1 is a local biomass resource assessment. The focus of this task is to assess local biomass resources, their availability, quantities, ease of access, and delivered projected cost. This is performed by providing an economic assessment of all of the local biomass resources in the Grand Forks regional area from local, state, and federal statistics. From the assessment, several biomass resources were chosen and a detailed assessment performed.

\section{Task 2 - Fireside Issues}

Task 2 addressed fuel mixing and fireside issues related to cofiring the most viable regional biomass resource as identified in Task 1 . Task 1 identified confectionary sunflower hulls as the most viable regional resource for cofiring. A survey was performed with current stoker-fired boiler systems using sunflower hulls as their primary fuel. From this survey, we obtained a list of potential problems associated with cofiring sunflower hulls and viable solutions. The second part of this task was to perform mixing, conveying, feeding, and combustion tests at the UND steam plant facility to assess the ability of the currently installed equipment to cofire sunflower hulls with coal. These tests were designed to identify problems with the current equipment and any modifications or new equipment purchases that would be necessary to enable the steam plant to cofire sunflower hulls.

\section{Task 3 - Fuel-Handling Issues}

Task 3 addressed biomass transportation and storage issues, as well as provided capital cost information on several equipment design configurations. A complete system design and preliminary equipment specifications were developed. The UND steam plant personnel provided initial specifications of equipment and input into the design of a fuel-handling and storage system. A cost analysis was also presented for the various system configurations.

\section{Task 4 - Engineering Economic Analysis}

Task 4 is an engineering economic analysis. An economic analysis was carried out using guidelines set forth by UND for evaluating new projects. Specific considerations include utility rate schedules and requirements for budgeting at state facilities. These considerations are necessary to make the document useful for the end user. The EERC, working with the UND Associate Director of Facilities and Planning, provided the analysis under this task. 


\section{Task 5 - Energy Production Assessment}

Task 5 addressed local permitting issues related to cofiring biomass at the UND steam plant facility. 


\section{RESULTS AND DISCUSSION}

\section{Task 1 - Local Biomass Resource Assessment}

\section{Background}

Under a current project, the EERC has developed a method for generating estimates of quantities of potential collectible biomass resources pertaining to small power systems. This method of estimation, based on documented resources for wood residue, agricultural residue, animal waste, sludge, and municipal solid waste (MSW) was used to get a rough assessment of the potential resources within a 100-mile radius of Grand Forks. Availability, reliability, source costs, delivery costs, and delivered condition were considered in determining the most viable resources for the more detailed survey. Availability is the ability of the biomass sources to provide the biomass year-round. The UND steam plant operates at much greater load during the winter months than the summer months. This operating cycle is generally opposite the biomass resource availability cycle, so it was one of the primary issues to look at. Reliability generally translated into a search for a large number of sources. This allowed redundancy in case the original sources were unable to meet their obligations. Both source cost and delivery costs were important in determining if the biomass resource could generate savings for the steam plant. Delivered condition was important in determining if the size and shape of the biomass resource were consistent and if additional processing would be necessary to enable cofiring.

The four major biomass resource groups can be defined as follows:

- Wood waste is the waste generated in primary and secondary processing of wood products. The mill waste (coarse and fine) typically consists of chips, trimmings, shavings, sawdust, bark chips, veneer chippings, cores, and pulp screenings.

- Farm waste includes crop residue and animal manure. Crop residue consists of collectible residues from the fields after accounting for the quantities required for the prevention of soil erosion due to wind and water. Animal manure is defined as the collectible dry manure from beef and dairy cattle, swine, sheep, and poultry.

- Agricultural processing waste comprises the waste generated during the processing of raw agricultural commodities.

- MSW is categorized as one of the biomass resources in addition to conventional organic sources. MSW without wood waste comprises the solid waste after recycling and composting. MSW wood includes all types of wood commonly found in mixed residential, commercial, and institutional waste streams. This includes wood residues produced by households and commercial generators that are typically handled by haulers and disposal facilities. Urban construction and demolition (C\&D) debris is material generated specifically by major construction activity and land clearing. Industrial wood waste is the waste wood from pallets and other sources.

Animal waste and crop residues are developed based on livestock population and crop production figures obtained from the National Agricultural Statistical Services (USDA, 1999). Collectible percentages are defined in Waldrop et al., 1994; Donavan, 1994; Downs et al., 1991, 
Zachrutz et al., 1990; and PEI, 1991. Mill and forest residue statistics are obtained from the timber product output database (USDA Forest Service, 1999). Assumptions referenced by the U.S. Department of Agriculture (USDA) under the definitions of mill and forest residue define the collectible quantity. In this study, we use $100 \%$ of this value. The following volume conversion factor is used for computations:

$1 \mathrm{mcf}=0.0125 \mathrm{MDBT}$ where $1 \mathrm{mcf}=1000 \mathrm{ft}^{2}$ and $1 \mathrm{MDBT}=1000$ dry bone tons

MSW data are obtained from EPA (1997). Definitions are as follows:

- Per capita generation of MSW in Year 2000: $4.42 \mathrm{lb} /$ person/day

- Per capita generation of MSW wood waste: $0.33 \mathrm{lb} /$ person/day

- Per capita generation of MSW excluding wood waste: $4.42-0.33=4.09 \times$ $\mathrm{lb} /$ person/day

- Per capita recovery of MSW through recycling and composting: $30 \%$

- Per capita MSW generation after recovery: $4.09 \times 0.7=2.863 \mathrm{lb} /$ person/day

The various sources of urban wood waste, including MSW, industrial wood, and C\&D, wood, are obtained from the national averages developed in (NREL, 1998):

- Per capita generation of urban wood waste in tons/year: $0.04 \times$ population

- Per capita generation of MSW urban wood: $0.33 \mathrm{lb} /$ day/person

- C\&D wood in tons/year: $0.09 \times$ population

\section{Resource Area}

This assessment was focused on biomass resources located in the counties surrounding the Grand Forks area. Biomass generally has a low bulk density, which makes transportation cost prohibitive for long distances. To minimize transportation cost, the resource assessment was performed on Minnesota and North Dakota counties within a 100-mile radius of Grand Forks. Figure 1-1 shows the counties that were surveyed, which include Grand Forks, Traill, Walsh, Nelson, Pembina, Cavalier, Ramsey, Eddy, Griggs, Barnes, and Steele Counties in North Dakota and Marshall, Kittson, Roseau, Pennington, Red Lake, Norman, Clay, Mahnomen, Polk, Beltrami, and Cass Counties in Minnesota.

\section{Regional Biomass Resources}

Table 1-1 provides a list of materials, their estimated annual quantities, and their annual quantity relative to the amount needed to cofire at a $30 \%$ higher heating value ratio with coal. These quantities are given in their raw state and do not take into account additional processing that might be necessary to prepare them for mixing and cofiring. 


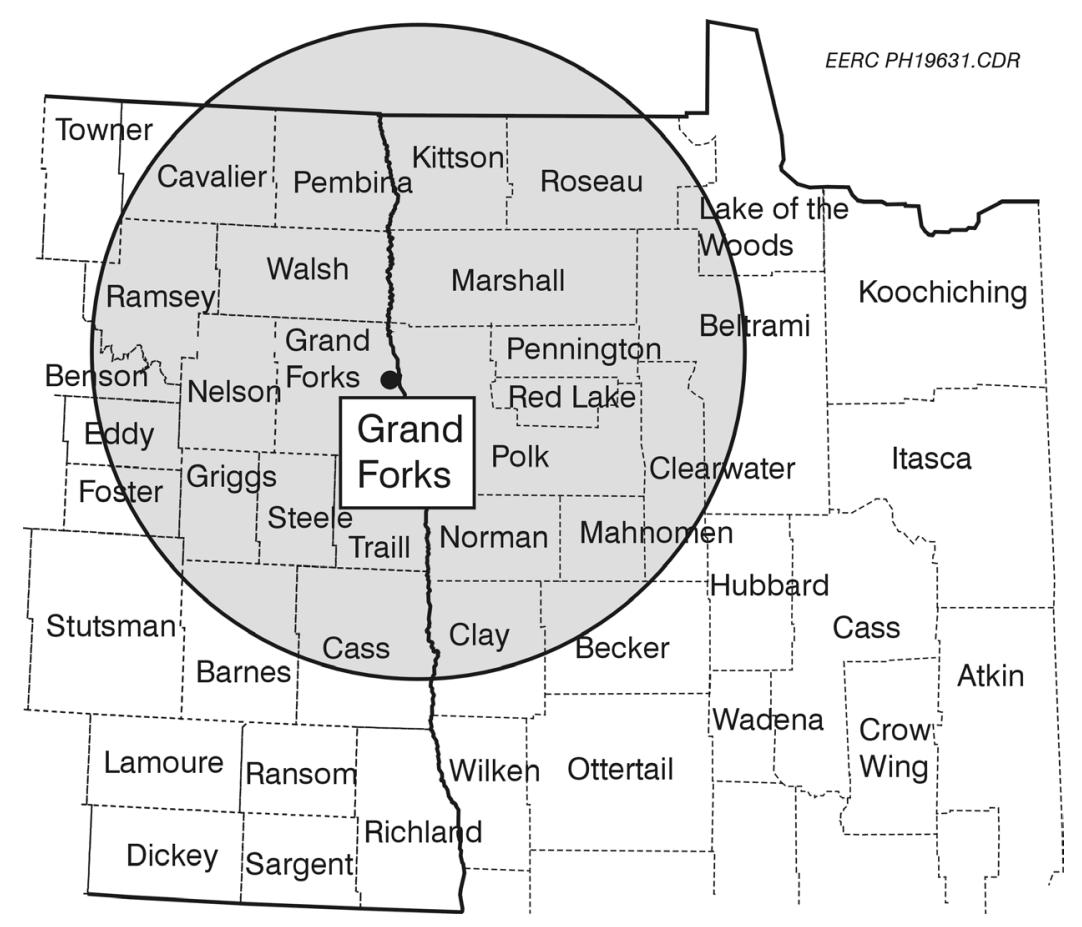

Figure 1-1. Counties within 100 miles of Grand Forks.

Table 1-1. Types of Biomass Available in Grand Forks Area

\begin{tabular}{llrc}
\hline Category of Biomass & \multicolumn{1}{c}{ Waste Stream } & tons per year & \% of the Project Demand \\
\hline Agricultural Production & Potato mash & 293,250 & 2255.8 \\
Wastes & Wet potato waste & 50,000 & 384.6 \\
& Dry potato waste & 743 & 5.7 \\
& Beet pulp & 495,940 & 3814.9 \\
& Beet tailings & 76,720 & 590.2 \\
& Sunflower hulls & 45,000 & 300 \\
Farm Wastes & Grain wastes & 132,000 & 882 \\
Urban Wastes & Animal manure & 45,135 & 347.2 \\
\multirow{2}{*}{ Wood Wastes } & Landfills & 13,052 & 100.4 \\
& UND & 284.2 & 2.2 \\
\hline
\end{tabular}

Although urban waste is shown to meet the minimum quantity requirements, their margin is too low for practical purposes. The biomass resources from wood waste, farm waste, and agricultural production waste meet the required quantities for the cofiring rate. The biomass resources in each of these categories were evaluated further to determine the quality and cost of the resource with respect to cofiring. 


\section{Agricultural Processing Wastes}

The primary agricultural residues available in the region are potato wastes from J.R. Simplot and RDO Foods, sugar beet waste, wastes from sunflower oil production, and bad quality or spoiled grain from elevators. The agricultural wastes in the Grand Forks area are summarized in Table 1-2.

Table 1-2. Agricultural Wastes in the Grand Forks Area

\begin{tabular}{lcc}
\hline Company & Waste Stream & tons per year \\
\hline J.R. Simplot & Potato mash & 293,250 \\
& Dry potato waste & \\
RDO Foods & Wet potato waste & 50,000 \\
& Dry potato waste & 743 \\
American Crystal Sugar Company & Beet pulp & 495,940 \\
& Beet tailings & 76,720 \\
Dahlgren & Sunflower hulls & 45,000 \\
Cargill & Sunflower hulls & 45,000 \\
Grain Elevators & Spoiled grain & 132,940 \\
\hline
\end{tabular}

Many other food producers also generate waste products, but because of the small amounts of their waste streams, these producers have not been taken into consideration.

Sugar Beet and By-Product Wastes

The largest waste from sugar production is beet pulp from American Crystal Sugar Company plants located in the Red River Valley. The main wastes from sugar production, which can be used as alternative fuel, include sugar beet tailings and peelings remaining after beet preparation and wet pulp that can be dried and pellitized. The beet pulp and pellets are sold as animal feed and command relatively high prices, making them less desirable compared to tailings, which are given away by some producers. The amount of tailings and peelings available varies seasonally and is not constant. A minimum amount is determined by production and can increase because of a frost or wet weather.

Beet tailings are the portion of the beet plant (including the roots) removed before the sugar production process begins. Sugar beets are typically cone-shaped, with two large vertical grooves from which masses of fibrous roots emerge. These roots help anchor the plant while it is in the ground, but they tend to hold soil, especially clay-type soils, when beets are harvested. These tailings, with a high percentage of dirt and debris, must be either returned to the farmer for tilling into the soil or disposed of as waste. American Crystal reports that its tailings are 50\% weeds and dirt and 50\% "beet chips," which are, in turn, $75 \%$ water. The $25 \%$ solid matter in the chips (or $12.50 \%$ of the tailings) could be used as a fuel. Daily amounts of wastes and their approximate costs are shown in Tables 1-3 and 1-4. 
Beet pulp is the fibrous vegetable matter left over after the sugar has been extracted from the sugar beet. It is generally dried, processed, and then sold as animal feed.

The wet pulp is not always utilized and frequently is given away, but because of the inconstant supply and the additional processing that would be required to prepare it for cofiring, it cannot be considered as a very reliable source.

Table 1-3. Sugar Beet Tailings

\begin{tabular}{lccc}
\hline Location & $\begin{array}{c}\text { Tailings } \\
\text { (tons/day) }\end{array}$ & $\begin{array}{c}\text { Tailings } \\
\text { (tons/year) }\end{array}$ & $\begin{array}{c}\text { Cost of Tailings } \\
\text { (\$/ton) }\end{array}$ \\
\hline East Grand Forks & 80 & 28,800 & $\$ 2.5$ \\
Hillsboro & 60 & 21,600 & $\$ 0$ \\
Drayton & 60 & 21,600 & $\$ 0$ \\
Crookston & 40 & 14,400 & $\$ 0$ \\
Totals & 280 & 100,800 & \\
\hline
\end{tabular}

Table 1-4. Sugar Beet Pulp

\begin{tabular}{lcrcccc}
\hline Location & $\begin{array}{c}\text { Wet Pulp } \\
\text { (tons/day) }\end{array}$ & $\begin{array}{c}\text { Wet Pulp } \\
\text { (tons/year) }\end{array}$ & $\begin{array}{c}\text { Cost of } \\
\text { Wet Pulp } \\
\text { (\$/ton) }\end{array}$ & $\begin{array}{c}\text { Dry Pulp } \\
\text { (tons/day) }\end{array}$ & $\begin{array}{c}\text { Dry Pulp } \\
\text { (tons/year) }\end{array}$ & $\begin{array}{c}\text { Cost of } \\
\text { Dry Pulp } \\
\text { (\$ton) }\end{array}$ \\
\hline $\begin{array}{l}\text { East Grand } \\
\text { Forks }\end{array}$ & 3,711 & $1,299,000$ & N/A & 440 & 154,000 & 12.50 \\
Hillsboro & 57 & 20,000 & 0 & 390 & 136,500 & 13.19 \\
Drayton & 3,812 & $1,114,000$ & N/A & 380 & 133,000 & 14.02 \\
Crookston & 2,520 & 882,000 & N/A & 300 & 105,000 & 18.62 \\
Totals & 10,100 & $3,315,000$ & & 1,510 & 528,500 & \\
\hline
\end{tabular}

Source: American Crystal Sugar - October 2000.

\section{Potato Processing Waste}

A typical potato processing plant handles 600 tons of raw potatoes a day. The process begins by washing extraneous matter from the incoming material and handpicking and disposing of those potatoes that are too small to process or those that have obviously spoiled. The washed potatoes are then conveyed to a steam-peeling device. For every ton of potatoes processed, approximately 160 pounds of peeling residue and "off-spec" potatoes is generated. This waste stream is typically $10 \%$ to $12 \%$. 
Peeled potatoes are conveyed over trimming and inspection belts in preparation for processing. Unpeeled portions, bruises, black spots, rotten parts, etc., must be removed by trimming and are diverted from the processing line. Slivers (thin slices) and nubbins (short or broken pieces) must be separated from the desired product after cutting into French fry strips.

The overall yield of raw French fries can be expected to fall within the range of $75 \%$ to $80 \%$ of the total raw materials. In addition to the 160 pounds of peeling residues, the process generates an additional 240 pounds of trim waste, slivers, and nubbins for every ton of potatoes processed (see Table 1-5).

Table 1-5. Potato Processing Waste

\begin{tabular}{lcccc}
\hline Wastes of & tons per day & tons per year & Cost per ton & Disposal Costs per ton \\
\hline Potato Mash & 739 & & 0 & $\$ 2$ \\
Wet Potato & & 43,478 & 0 & $\$ 7$ \\
Dry Potato & 652 & 0 & $\$ 7$
\end{tabular}

Source: J.R. Simplot - October 2000.

J.R. Simplot operates a potato processing facility in Grand Forks that generates 1.7 million pounds of waste potato mash each day. The mash is approximately $5.2 \%$ starch, $6.1 \%$ inert organics, and the balance is water. Assuming the facility operates 345 days a year, annual waste production is 587 million pounds of potato mash. Simplot reports the current disposal cost at $\$ 576,000$ annually, or about $\$ 2.00$ per ton.

RDO Foods operates a potato processing facility in Grand Forks that generates approximately 100 million pounds of wet (13\%-16\% solids) waste and 1.5 million pounds of dry ( $92 \%$ solids) waste material a year. Approximately $50 \%$ of the solids content in the wet material is starch and $1 \%-3 \%$ is sugar, while the dry material contains $60 \%-70 \%$ starch and $1 \%-3 \%$ sugar. The material currently is being given away as cattle and mink feed at a disposal cost to the company of about $\$ 350,000$ per year (about $\$ 7.00$ per ton). The material is available nearly yearround via truck transportation.

\section{Sunflower Seeds Processing}

The closest sunflower processing plant to Grand Forks is Dahlgren \& Company Inc. located in Crookston, Minnesota. Dahlgren \& Company Inc. produces a number of sunflower products, generating 30,000-45,000 tons of sunflower hulls a year. The plant is operating yearround with the waste production equally spread throughout the year.

Sunflower hulls have a relatively high heating value. Hulls are dry after the crushing process and stored in silos designed to keep the moisture level down. Other uses of the sunflower hulls are as poultry bedding and fiber for cardboard boxes. 
The only raw material used in the production process is sunflower seeds. This provides a very uniform biomass source with respect to size, shape, and chemical makeup (see Table 1-6).

Table 1-6. Sunflower Seed Hulls

\begin{tabular}{lcc}
\hline Sunflower Seed Hulls & tons/year & Cost $\$ /$ ton \\
\hline Confection & 30,000 & $\$ 12$ \\
Oil & 15,000 & $\$ 12$ \\
Ground Hulls & $1 / 3$ of the total & $\$ 14$ \\
Total & 45,000 & \\
\hline
\end{tabular}

Source: Dahlgren \& Company Inc. - November 2000.

\section{Farm Waste}

\section{Livestock and Poultry Residuals}

The main by-product of livestock and poultry farms is manure. Manure has value as both a soil conditioner and an alternative fuel. The nutrient and heating value of manures varies, depending on the type and age of the animal (beef cow, dairy cow, calf, finisher pig, broiler, layer, turkeys etc.), the nutrients in the animal feed, and the manure collection, storage, and spreading method used.

Manure is considered to be a soil conditioner when it is applied to farmland to improve the physical characteristics of the soil. The primary utilization of manure by farmers at this time is as a fertilizer for crop production. An alternative to direct land application of dairy cattle manure is to use it as a fuel.

In some cases, manure contains bedding (wood waste or straw) up to $75 \%$. This type of manure is not an optimal fertilizer because of its high carbon:nitrogen ratio and much longer decomposition time. Therefore, this type of manure is readily available. It also has high energy content. An advantage of the mixed bedding and manure is the fact that it has a higher marginal weight than pure sunflower hulls, sawdust, or straw. This makes it easier to mix and cheaper to transport.

Quantities of animal wastes available are developed based on the livestock population in the Grand Forks surrounding area. The data were obtained from National Agricultural Statistical Services (USDA). The following charts show the distribution of the livestock in counties surrounding Grand Forks (see Figures 1-2-4). The total amounts of animal wastes available are calculated on the basis of statistical data. The values are summarized in Table 1-7. 
The collectible percentage of the animal wastes is defined in Waldrop et al. (1994), Donavan (1994), Downs et al. (1991), Zachrutz et al. (1990), and PEI (1991).

For cattle manure production, the most populated county in the area is Cass County. Cass County produces about $11 \%$ of all cattle manure in the area. The northern border of the county is 60 miles away from Grand Forks. Transportation costs for manure shipped in this area will substantially increase the costs.

The largest number of hogs is raised in Grand Forks County. Transportation costs are not high, but the sources are not concentrated in one place, and the amounts available cannot cover the demand for biomass fuel in full.

The largest number of sheep is in Barnes County, which is also 60 miles away from Grand Forks.

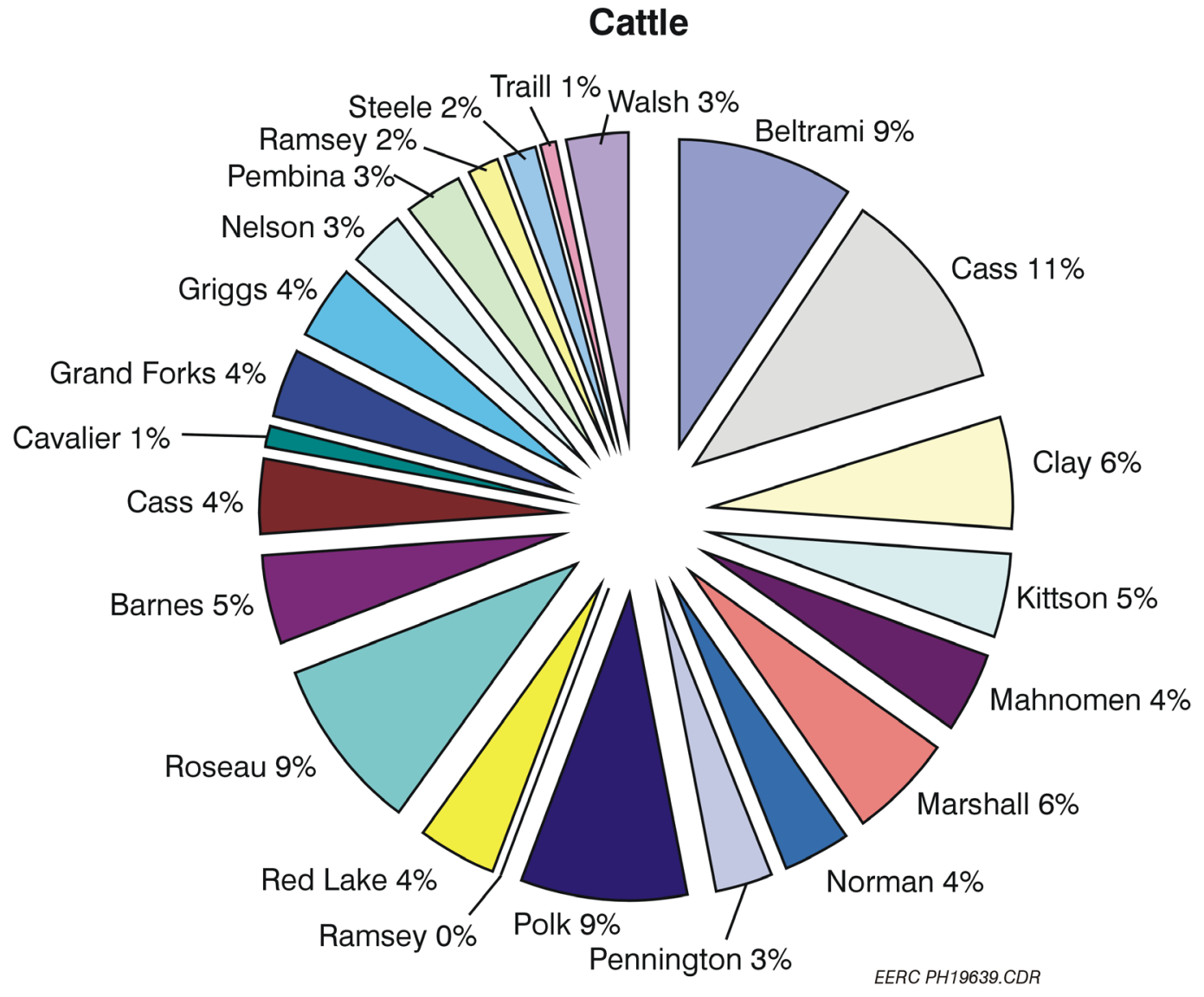

Figure 1-2. Distribution of cattle in counties surrounding Grand Forks. 


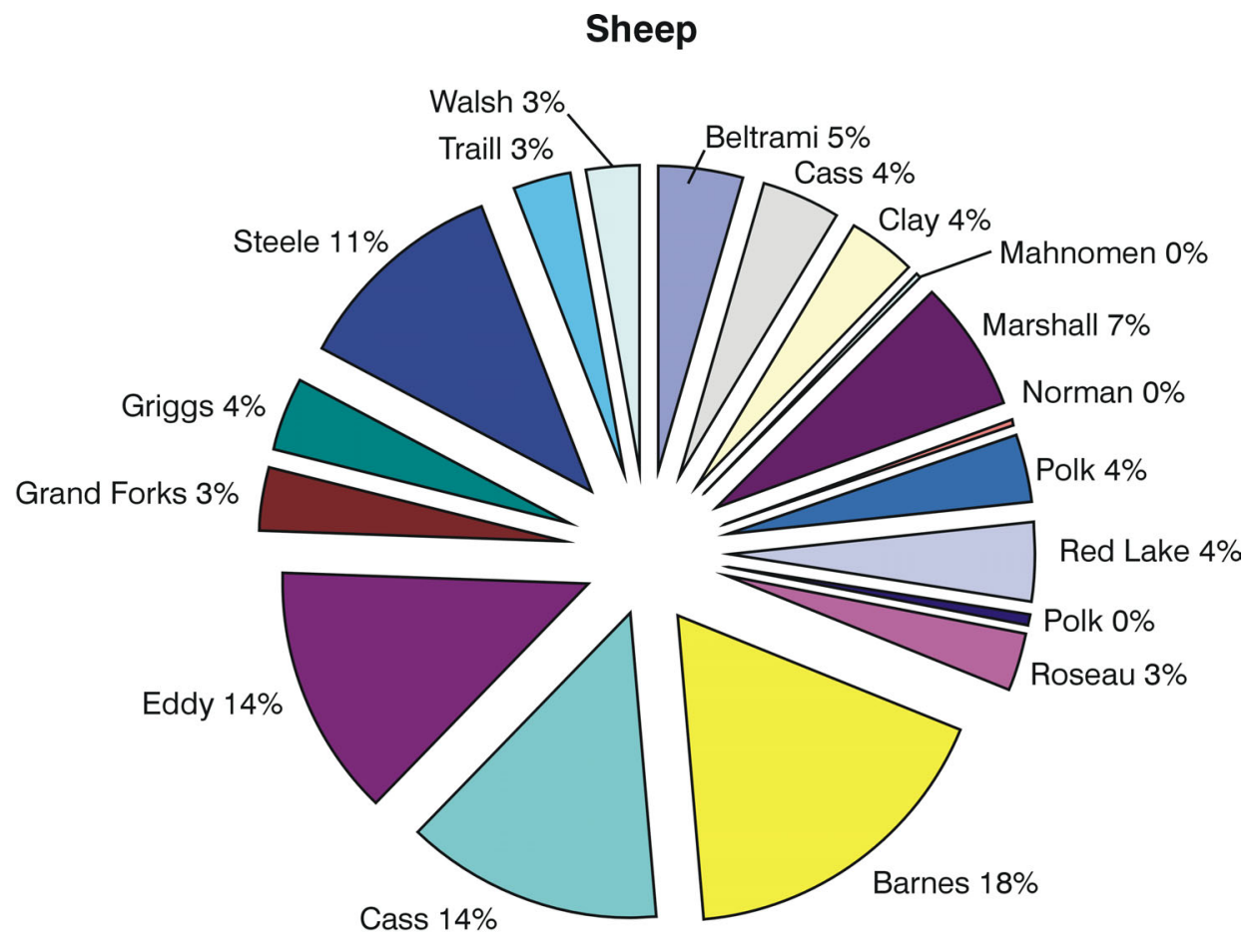

EERC PH19638.CDR

Figure 1-3. Distribution of sheep in counties surrounding Grand Forks.

Hogs

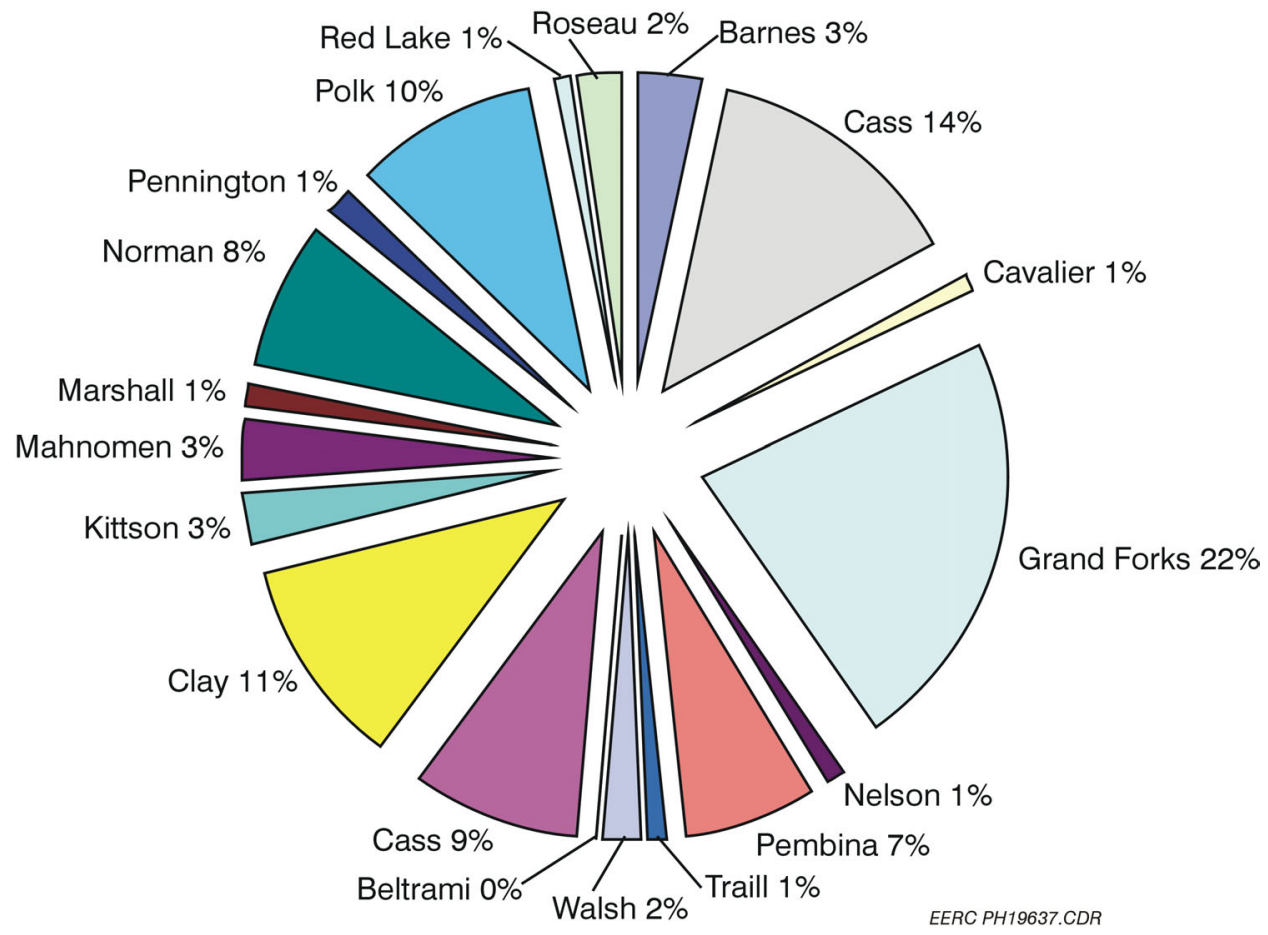

Figure 1-4. Distribution of hogs in counties surrounding Grand Forks. 
Table 1-7. Animal Wastes

\begin{tabular}{lccc}
\hline Livestock & Head & $\begin{array}{c}\text { Dry Manure per Head } \\
\text { (tons/year) }\end{array}$ & $\begin{array}{c}\text { Total } \\
\text { (tons/year) }\end{array}$ \\
\hline Milk and Beef Cows & 86,100 & 1.7 & 146,370 \\
Cattle and Calves & 328,200 & 0.73 & 246,150 \\
Hogs and Pigs & 85,900 & 0.27 & 23,193 \\
Chickens & 270,000 & 0.01644 & $4,438.80$ \\
Sheep and Lamb & 22,000 & 0.053 & 1,117 \\
Turkey from the & & & \\
$\quad$ Largest Source & N/A & N/A & 27,000 \\
\hline
\end{tabular}

Source: USDA Annual statistics, October-November 2000.

Two additional considerations must be taken into account when cofiring livestock manure is considered. The steam plant requires the collection and storage of enough biomass reserve to cover $30 \%$ cofiring for 7 days is considered. The sanitary conditions that must be met to store biomass in a highly populated area may make manure an unfeasible option. The primary issue is overcoming the odor control problems associated with transporting and storing a very large quantity of manure on a university campus. Also, high-moisture manure may present an unacceptable biological hazard.

One possible option to overcome these barriers is by adding bedding to the manure. Bedding acts as both an odor filter and moisture absorber. Manure with bedding content of over $60 \%$ may be a feasible option. Turkey manure in the area contains $70 \%-75 \%$ sunflower hull bedding. This type of manure is collected from the turkey farms by a separate manure handler and then sold to area farms as fertilizer for $\$ 10 /$ ton.

\section{Crop Residuals}

Crop residuals are the stalks left over in the field after the grain has been harvested. There are several advantages to leaving crop residues in the field: soil erosion control, soil nutrient, and fertility and snow maintenance. These residuals can also be removed from the field and used for the livestock feed and bedding.

Table 1-8 shows the total amount of crop residues in the Grand Forks region and surrounding counties. The amount of small grain residues is also presented.

For crop residues left in the field, there is no other ready market in North Dakota, so a market value has not been established. We used the method of a relevant opportunity cost to estimate the value of this type of crop residual. The relevant opportunity cost of a crop residue is its value to subsequent crops and future land productivity when left on the field, plus the cost of assembly or collection and transportation. A cost breakdown for crop residuals available in North Dakota is presented in Tables 1-9-11. 
Table 1-8. Average Collectible Crop Residuals in North Dakota (thousand tons a year)

\begin{tabular}{lcc} 
County & Total Crop Residue & Small Grain \\
\hline Grand Forks & 854 & 675 \\
Traill & 612 & 511 \\
Walsh & 770 & 596 \\
Nelson & 495 & 366 \\
Pembina & 673 & 553 \\
Cavalier & 860 & 820 \\
Ramsey & 500 & 442 \\
Eddy & 234 & 114 \\
Griggs & 345 & 230 \\
Steele & 426 & 357 \\
Barnes & 748 & 567 \\
\hline
\end{tabular}

Table 1-9. Fertilizer Value of Crop Residues per Ton

\begin{tabular}{lccc}
\hline Type of Residue & Nitrogen & Phosphate & Total \\
\hline Wheat Straw & $\$ 1.33$ & $\$ 0.64$ & $\$ 1.97$ \\
Oat Straw & $\$ 1.59$ & $\$ 0.84$ & $\$ 2.43$ \\
Barley Straw & $\$ 1.51$ & $\$ 0.84$ & $\$ 2.35$ \\
Corn Straw & $\$ 1.95$ & $\$ 2.12$ & $\$ 4.35$ \\
Soybean Residue & $\$ 1.87$ & $\$ 0.48$ & $\$ 2.35$ \\
Sunflower Stalks & $\$ 1.74$ & $\$ 1.36$ & $\$ 3.10$ \\
Flax Straw & $\$ 1.53$ & $\$ 0.48$ & $\$ 2.01$ \\
\hline
\end{tabular}

\section{Table 1-10. Crop Residuals Collection Cost}

\begin{tabular}{lrrrr}
\hline & \multicolumn{3}{c}{ Payments, dollars per dry ton } \\
\hline Radius, miles: & $0-15$ & $16-30$ & $31-50$ & $51-100$ \\
\hline Bailer's Revenue & 10.72 & 10.72 & 10.72 & 10.72 \\
Hauler's Revenue & 4.94 & 6.12 & 9.66 & 17.92 \\
Producer's Revenue & 15.00 & 12.33 & 9.66 & 7.00 \\
Total Cost & 30.66 & 29.17 & 30.04 & 35.64 \\
\hline
\end{tabular}


Table 1-11. Average Cost of the Crop Residues per Ton

\begin{tabular}{lccc}
\hline Type of Residue & Fertilizer Value, $\$$ & Average Collection Cost, $\$$ & Total, $\$$ \\
\hline Wheat Straw & 1.97 & 31.38 & 33.35 \\
Oat Straw & 2.43 & 31.38 & 33.81 \\
Barley Straw & 2.35 & 31.38 & 33.73 \\
Corn Straw & 4.35 & 31.38 & 35.73 \\
Soybean Residue & 2.35 & 31.38 & 33.73 \\
Sunflower Stalks & 3.10 & 31.38 & 34.48 \\
Flax Straw & 2.01 & 31.38 & 33.39 \\
\hline
\end{tabular}

The collection and hauling cost of using crop residues for cofiring run between $\$ 33$ and $\$ 36$ per ton. From an economic standpoint, crop residues present very little potential to save money in a cofiring scheme.

\section{City of Grand Forks Urban Waste}

The City of Grand Forks generates approximately 30,000 tons of different types of solid wastes a year. Landfilled industrial waste and bush were identified as the most viable biomass cofiring fuels from this group. Yard waste, which is also generated in large quantities, has a low content of combustible materials. For this to be a viable cofiring fuel, it must be mixed with other forms of waste.

The data in Table 1-12 represent distribution of the wastes disposed of at the City of Grand Forks Landfill.

Table 1-12. City of Grand Forks Annual Urban Waste Production, tons/year

\begin{tabular}{lcccc}
\hline & 1996 & 1997 & 1998 & 1999 \\
\hline Yard Waste & 3,720 & 3,720 & 4,425 & 4,523 \\
Landfilled Industrial Waste & - & - & 4,230 & 3,950 \\
Brush & 4,238 & 4,238 & 3,572 & 8,530 \\
Total & 3,720 & 3,720 & 14,225 & 19,002 \\
\hline
\end{tabular}

Source: City of Grand Forks Landfill.

Landfilled industrial wastes come from the following sources: pallet companies, truss companies, wholesale and retail lumber companies, woodworking companies, and C\&D wood wastes generated primarily from residential construction. C\&D industrial waste is often mixed with other debris from the construction site and usually disposed of at the lowest-cost C\&D landfills. The contaminants in this waste make it less attractive for cofiring, since the contaminants must be segregated from the wood prior to its use. The share of wood in C\&D waste is usually no higher than $50 \%$. Given the low quantity of industrial waste in Grand Forks, it would have to be supplemented by other types of biomass to cofire above $20 \%$.

Another industrial waste stream is industrial wood and paper wastes. Industrial producers can generate a considerable amount of packaging material in their production process. This 
category of waste includes pallets, cardboard, and other packaging materials used to transport materials for the production process. The approximate amount of this category is indicated in Table 1-13.

Table 1-13. Industrial Wood and Paper Wastes

\begin{tabular}{lccc}
\hline & $\begin{array}{c}\text { Paper and } \\
\text { Cardboard }\end{array}$ & Pallets & $\begin{array}{c}\text { Total, } \\
\text { tons }\end{array}$ \\
\hline Integrity Windows & 60 & 71 & 131 \\
Simplot & 50 & 18 & 68 \\
Conte Luna Foods & 60 & 50 & 110 \\
\hline
\end{tabular}

The main constituent of the industrial waste comes from pallets, packaging materials, and other sources. In general, individual producers generate small quantities of this type of waste. Therefore, use of this type of material is possible only when a large number of producers are contracted for delivery of their waste-packaging materials.

Brush is available in considerable amounts in the Grand Forks area. The cost of the brush depends on preparation for transportation and use, typically accomplished by contracting or operating a tub grinder. The capital cost of a tub grinder is $\$ 250,000$, and annual maintenance expenses are approximately $\$ 50,000$.

If the grinder works for 5 years, the cost per ton of brush during this time period will be approximately $\$ 10.55$; for 4 years of use, the price will be $\$ 11.72$, etc. (see Table 1-14).

Table 1-14. Cost/ton of Brush for Various Time Periods

\begin{tabular}{lllll}
\hline 1 year of Use & 2 years & 3 years & 4 years & 5 years \\
\hline$\$ 29.30$ & $\$ 17.58$ & $\$ 13.67$ & $\$ 11.72$ & $\$ 10.55$ \\
\hline
\end{tabular}

\section{UND Wastes}

Wastes generated by UND that can be used as a fuel are mainly paper and plastic gathered from around the campus. Since the year 2000, a recycling program has been collecting paper and plastic from around the campus, so collection costs have already been budgeted by the University. This type of waste is seasonal, with the largest quantities collected during the fall and winter semesters. Table 1-15 gives the amount and estimated collection costs of UND-generated waste paper and plastic. 
Table 1-15. UND Wastes

\begin{tabular}{lcc}
\hline Wastes & tons/year 2000 & Price of Utilization, \$/ton \\
\hline Paper & 280 & 8 \\
Plastic & 4.2 & 8 \\
Total & 284.2 & 2,273 \\
\hline
\end{tabular}

Source: UND Facilities Department.

The seasonal nature and amount of wastes generated by UND is not suitable for it to be used as the sole source of cofiring fuel, so it should be considered as a supplemental fuel source for cofiring.

\section{Wood Processors}

Primary

Primary wood processors are industries that use round wood to manufacture a variety of products. A large number of primary wood processors are located in Minnesota in the Bemidji and Ada areas. Mills located in this area generate about 1.8 million tons of green wastes a year. Nearly $7 \%$, or 117,100 tons, of these wastes is currently not utilized. $95 \%$ of the nonutilized volume, 110,300 green tons, is found at small and middle-size sawmills distributed throughout these counties. This is a very cyclical source of biomass for cofiring, with the largest amounts available during the summer months.

Middle-size mills that generate around 10 tons of sawdust and wood residuals a day sell the majority of their residues. What residues the mills do not sell is given away or burned, about 4-6 tons a day.

The amount of wastes left after the wood processing is shown in Table 1-16.

Table 1-16. Primary Wood Processor Wastes

\begin{tabular}{lccccc}
\hline & $\begin{array}{c}\text { Sawdust and } \\
\text { Shavings, } \\
\text { tons/year }\end{array}$ & $\begin{array}{c}\text { Bark, } \\
\text { tons/year }\end{array}$ & $\begin{array}{c}\text { Slabs and } \\
\text { Edgings, } \\
\text { tons/year }\end{array}$ & $\begin{array}{c}\text { Total, } \\
\text { tons }\end{array}$ & Price/ton \\
\hline $\begin{array}{c}\text { Saw Mills and Related } \\
\text { Industries }\end{array}$ & 244,000 & 483,250 & 137,450 & 864,800 & $\$ 25$ \\
$\begin{array}{c}\text { By One Middle-Size } \\
\text { Sawmill }\end{array}$ & 1,500 & & 2.500 & 4,000 & $\$ 4$ \\
\hline
\end{tabular}

Source: Wagner sawmill and Minnesota Waste Wood Studies.

There is a market for large of amounts residue from primary processors. Therefore, prices from the big producers are relatively high compared to the small producers, who charge only for loading the materials. 


\section{Secondary}

Secondary wood processors use solid lumber, plywood or particleboard, and a wide variety of wood species in their manufacturing operations. Depending on the products manufactured, they may use other types of materials such as plastic, or paper overlays, metals, glues, paint, and a variety of finishes.

The largest category of waste wood from secondary wood industries is mixed-wood waste. These materials are collected in a common container before disposal and may include metals, plastic, and other nonwood wastes. Contaminants such as plastic or paper overlays, metals, glues, paint, and a variety of finishes restrict the use of wood wastes. Air quality concerns may limit the use of some wastes for fuel.

Some companies do keep their wastes segregated for a number of reasons. The broad categories of segregated wastes are:

- Lumber scraps

- Sawdust

- Shavings

- Panel scraps with plastic and without

- Treated wood

- Chips/hogged

- Mixtures

Because of low waste production, companies with fewer than 100 employees must dump or landfill. Because they do not handle a large volume of material, they often have more difficulties finding alternatives to landfilling their wood wastes. Larger companies have progressively smaller disposal problems. The amounts of secondary wood processor wastes from two small companies in the Grand Forks area are shown in Table 1-17.

Table 1-17. Secondary Wood Processor Wastes

\begin{tabular}{lcccc}
\hline & $\begin{array}{c}\text { Sawdust and } \\
\text { Shavings, } \\
\text { tons/year }\end{array}$ & $\begin{array}{c}\text { Slabs and } \\
\text { Edgings, } \\
\text { tons/year }\end{array}$ & $\begin{array}{c}\text { Pallets, } \\
\text { Cardboard etc., } \\
\text { tons/year }\end{array}$ & $\begin{array}{c}\text { Total, } \\
\text { tons/year }\end{array}$ \\
\hline Integrity Windows & 1 & 2 & 70 & 72 \\
Braaten Cabinets & 2 & 3 & 6 & 11 \\
\hline
\end{tabular}

Integrity Windows and Braaten Cabinets; November 2000.

The volumes of the waste streams require organizing a large pool (more than 100) of suppliers of this kind of biomass in order to satisfy demand in fuel for the cofiring.

\section{Construction and Demolition Wood Waste}

The wood waste that is left over after C\&D of buildings is commonly hauled to demolition landfills. Wood from cutting old pallets and from manufacturing operations is also hauled to 
these sites. Most of this residue is contaminated with metal, paint, plastic, and other materials. Therefore, the cost of the wood recovery is hard to estimate. A share of wood in total wastes delivered to landfills is about $40 \%$ relative to the total C\&D residuals (see Table 1-18).

Table 1-18. Demolition Wood Wastes

\begin{tabular}{lcc}
\hline Composites & $\%$ in Total Wastes & tons/year \\
\hline Total (unsegregated) & $100 \%$ & 3,640 \\
Wood & $42,5 \%$ & 1,547 \\
Metal & $3 \%$ & 109.2 \\
Roofing & $23 \%$ & 837.2 \\
Drywall & $8 \%$ & 291.2 \\
Concrete, Bricks & $9 \%$ & 327.6 \\
Dirt, Gravel & $5 \%$ & 182 \\
Other & $9,5 \%$ & 345.8 \\
\hline
\end{tabular}

Source: Wagner Sawmill and Minnesota Waste Wood Studies.

\section{Evaluation of Biomass Resources}

A coal/biomass heating value ratio was used to estimate the quantity of biomass needed to substitute for subbituminous coal in the UND Steam Plant. The ratios for different types of biomass and quantity of fuels are given in Table 1-19.

Table 1-19. Comparative Analysis Data (coal vs. biomass)

\begin{tabular}{lcccc}
\hline Fuel & $\begin{array}{c}\text { Calorific Value, } \\
\mathrm{kJ} / \mathrm{kg}\end{array}$ & $\begin{array}{c}\text { Ratio } \\
\text { Coal/Biomass }\end{array}$ & $\begin{array}{c}\text { tons per year, } \\
100 \% \text { substitute }\end{array}$ & $\begin{array}{c}\text { tons per year, } \\
30 \% \text { substitute }\end{array}$ \\
\hline Coal & 19,899 & 1.00 & 45,000 & 15,000 \\
Sunflower Hulls & 21,227 & 0.94 & 42,164 & 14,055 \\
Waste Wood & 18,940 & 1.05 & 47,255 & 15,752 \\
Sawdust Small Producer & 17,380 & 1.14 & 51,496 & 17,165 \\
Sawdust Large Producer & 17,380 & 1.14 & 51,496 & 17,165 \\
Pallets, etc. & 19,485 & 1.02 & 45,933 & 15,311 \\
Plastic & 43,100 & 0.46 & 20,766 & 6,922 \\
MSW & 12,199 & 1.63 & 73,367 & 24,456 \\
Paper & 15,614 & 1.27 & 57,321 & 19,107 \\
Sugar Beet Pulp & 16,600 & 1.20 & 53,916 & 17,972 \\
Sugar Beet Edges & 16,250 & 1.22 & 110,154 & 45,898 \\
Poultry Manure & 15,488 & 1.28 & 57,787 & 19,262 \\
Grain Waste & 17,039 & 1.17 & 52,527 & 17,509 \\
Straw & 17,628 & 1.13 & 50,772 & 16,924 \\
\hline
\end{tabular}

Table 1-20 shows related costs of biomass available in a 100-mile radius from Grand Forks for cofiring. The costs of the different types of biomass in Table 1-20 were calculated as the 


\begin{tabular}{|c|c|c|c|c|c|c|c|}
\hline Type of Biomass & Price & $\begin{array}{c}\text { Collection } \\
\text { Cost }\end{array}$ & $\begin{array}{c}\text { H\&S Cost and } \\
\text { Transportation } \\
\text { Cost }\end{array}$ & $\begin{array}{c}\text { Total } \\
\text { Cost per } \\
\text { ton }\end{array}$ & $\begin{array}{c}\text { Ton per Year } \\
(30 \% \\
\text { substitute }) \\
\end{array}$ & Total Cost & $\begin{array}{c}\text { Gross } \\
\text { Substitution } \\
\text { Effect } \\
\text { (fuel only) }\end{array}$ \\
\hline Coal & $\$ 35$ & - & - & $\$ 35$ & 15,000 & $\$ 525,000$ & 0 \\
\hline Sunflower Hulls & $\$ 10$ & - & $\$ 5$ & $\$ 15$ & 23,434 & $\$ 351,510$ & $\$ 173,490$ \\
\hline $\begin{array}{l}\text { Waste Wood, } \\
\text { brush }\end{array}$ & $\$ 10.55$ & - & $\$ 4$ & $\$ 14.55$ & 25,026 & $\$ 229,186$ & $\$ 295,814$ \\
\hline $\begin{array}{l}\text { Sawdust, } \\
\text { small producer }\end{array}$ & $\$ 4$ & $\$ 5$ & $\$ 7$ & $\$ 16$ & 27,273 & $\$ 274,647$ & $\$ 250,353$ \\
\hline $\begin{array}{l}\text { Sawdust, } \\
\text { large producer }\end{array}$ & $\$ 25$ & - & $\$ 7$ & $\$ 31$ & 27,273 & $\$ 1,596,384$ & $(\$ 7,128)$ \\
\hline Pallets etc. & - & - & $\$ 10$ & $\$ 10$ & 24,326 & $\$ 153,110$ & $\$ 1,797$ \\
\hline Plastic & - & - & 一 & $\$ 0$ & 10,998 & $\$ 0$ & $\$ 319$ \\
\hline MSW & - & $\$ 4$ & $\$ 4$ & $\$ 8$ & 38,856 & $\$ 195,646$ & $\$ 3,294$ \\
\hline Paper & - & - & - & $\$ 0$ & 30,357 & $\$ 0$ & $\$ 7,694$ \\
\hline Sugar Beet Pulp & $\$ 12.50$ & - & $\$ 4$ & $\$ 16.50$ & 28,554 & $\$ 296,538$ & $\$ 228,462$ \\
\hline Sugar Beet Edges & $\$ 2.50$ & - & $\$ 5$ & $\$ 7.50$ & 72,923 & $\$ 344,233$ & $\$ 180,767$ \\
\hline Poultry Manure & $\$ 16$ & - & - & $\$ 15$ & 30,604 & $\$ 288,935$ & $\$ 236,065$ \\
\hline Grain Waste & $\$ 40$ & - & $\$ 6$ & $\$ 46$ & 27,819 & $\$ 805,412$ & $(\$ 280,412)$ \\
\hline $\begin{array}{l}\text { Straw } \\
\text { Poultry Manure }\end{array}$ & $\$ 34.30$ & - & $\$ 7$ & $\$ 41.30$ & 26,889 & $\$ 698,958$ & $(\$ 173,958)$ \\
\hline Mix & & & & $\$ 15.00$ & 24,892 & $\$ 226,100$ & $\$ 298,900$ \\
\hline
\end{tabular}

original cost or a price, determined from collection cost, transportation cost, and handling and storing $(\mathrm{H} \& \mathrm{~S})$ cost.

The comparative analysis reveals that sunflower hulls, wood waste, sawdust, poultry manure/mix, and sugar beet waste are viable regional biomass resources for cofiring. Of these resources, the sugar beet wastes need additional posttransportation processing such as drying. This would require additional storage and drying equipment. Manure mix is generally composed of $70 \%-75 \%$ sunflower hulls. This mix has a high heating value and is the second most attractive biomass fuel. Turkey manure can be acquired from a single source at 25,000 tons/year for $\$ 15 /$ ton, which is half the current energy cost of UND. Both sunflower hulls and manure mix are waste streams of a production process; therefore, they are available year-round, and the amounts generated are relatively stable. Odor control problems associated with the transportation and storage of manure on a major university campus eliminate it from contention, however.

Factors such as reliability, quantity available, and seasonality play critical roles in determining the acceptability of a specific biomass resource. The criteria given in Table 1-21 are used to help evaluate the most efficient types of biomass. Table 1-22 shows the ranking of the biomass resources based on several factors. 
Table 1-21. Criteria for Biomass Cost-Effectiveness

\begin{tabular}{|c|c|c|c|}
\hline Criteria & 1 & 2 & 3 \\
\hline Price & $>\$ 15$ & $\$ 15-\$ 10$ & $<\$ 10$ \\
\hline Quantity & $100 \%-150 \%$ & $200 \%-300 \%$ & $>300 \%$ \\
\hline Availability & Spring-Summer & Fall-Winter & $\begin{array}{l}\text { Equally Distributed } \\
\text { Year-Around }\end{array}$ \\
\hline Quality & $>40 \%$ moisture & $40 \%-15 \%$ moisture & $<15 \%$ moisture \\
\hline $\begin{array}{l}\text { Energy Efficiency, } \\
\text { coal/biomass Btu ratio }\end{array}$ & $>2$ & $1-2$ & $<1$ \\
\hline Reliability & Fair & Relatively reliable & Very reliable \\
\hline $\begin{array}{l}\text { Annual Cost Savings } \\
\text { Potential }\end{array}$ & $<\$ 100,000$ & $\$ 100,000-\$ 200,000$ & $>\$ 200,000$ \\
\hline
\end{tabular}

Table 1-22. Evaluation Table (ranking 3 = good, 1 = poor)

\begin{tabular}{lccc}
\hline Criteria/Biomass & Sunflower Hulls & Wood Waste & Sawdust \\
\hline Price & 3 & 2 & 1 \\
Quantity & 3 & 1 & 3 \\
Availability & 3 & 2 & 2 \\
Quality & 3 & 3 & 3 \\
Energy Efficiency, & & & \\
$\quad$ coal/biomass Btu ratio & 3 & 2 & 2 \\
Reliability & 2 & 1 & 1 \\
Effect & 3 & 2 & 1 \\
Total & 20 & 13 & 13 \\
\hline
\end{tabular}

Based on the above criteria of the three remaining viable biomass types, sunflower hulls are shown to be the optimum choice for cofiring.

Sunflower hull processing plants are located in West Fargo, Enderlin, and Crookston. The plant located in Crookston produces a variety of products from confectionary sunflower seeds. This plant generates 45,000 tons of sunflower hulls a year, mostly confectionary sunflower hulls. Currently, sunflower hulls are used as animal bedding or disposed of in a landfill.

The plants located in Fargo and Enderlin produce oil from sunflower seeds. The plant located in Enderlin burns all of its waste sunflower hulls to generate steam and electricity. The plant in Fargo uses some of its waste sunflower hulls for steam production and sells the rest to farmers for animal bedding.

Another attractive biomass source is brush (wood waste) collected by the Grand Forks Landfill during the spring-summer season. It is stored in pales and is not permitted to be burned; therefore, the utilization of the wood brush by UND will be beneficial for both the University and the landfill. The brushwood consists of branches of trees, old trees, and bushes. The size of 
the biomass indicates additional preparation is necessary. Another lowering value factor is the seasonal availability of the brush supply and changing volume from year to year.

The third prospective type of biomass is sawdust. Only the small-sized sawmills are considered viable resources because the lack of demand for the small quantities of sawdust they produce results in a low price. A quantity of 50,000 tons/year is available in the form of sawdust, edgings, logs, boards, and bark.

\section{Conclusion}

Biomass being considered for cofiring is sunflower hulls, turkey manure, sawdust, and municipal wood. The most significant resources in terms of quantity are sunflower hulls and sawdust at over 45,360 tonnes/year (50,000 tons/year) each. Turkey manure and municipal wood are available at less than $50 \%$ of UND's total consumption. Most likely, UND will choose to fire sunflower hulls or sawdust based on delivered costs in the $\$ 15$ to $\$ 25 /$ ton range compared to coal at \$30/ton. Municipal wood presents fuel preparation and handling difficulties, and turkey manure, despite the attractive low cost, presents odor control issues. 


\section{Task 2 - Fuel-Handling and Fireside Issues}

\section{Introduction}

Although most environmentalists consider the utilization of biomass a "green" energy source, concerns with air and water pollution and solids waste disposal can diminish this green perception. Fuel handling can generate significant quantities of dust. In addition to dust handling, combustion of biomass forms a fine particulate that must be collected. Water contamination can occur from runoff of exposed storage piles. If not handled properly, biomass can spoil and pose a health hazard. Ash quality can be affected by fuel variability and impurities, impacting its salability and/or disposal requirements. Feed problems can occur due to the physical characteristics of the biomass. These aspects must be addressed to maintain a good public perspective on the utilization of biomass for energy.

Mitigation of these issues requires the installation of additional equipment, which may vary depending on the type of biomass used. The resource assessment is vital in narrowing the scope of biomass products available for cofiring, so that the most cost-effective choice of equipment can be investigated for the most likely biomass resources. Upon completion of the local biomass resource assessment, confectionary sunflower hulls were chosen as one of the optimal local biomass resources for cofiring at the UND steam plant because of its combination of price, availability, and the need for minimal or no additional processing prior to combustion. Sunflower hulls are readily available within the Grand Forks area and could be delivered to the UND steam plant for between $\$ 15$ and $\$ 25$ per ton. The sunflower hulls were consistent in size and shape and were delivered dry, so that no additional processing was necessary to prepare it for combusting. This section will investigate issues specific to metering, mixing, feeding and combusting sunflower hulls in a cofiring scheme with coal.

\section{Goals and Objectives}

The goal of this task is to design a mixing, conveyance, feeding, and combustion system for cofiring confectionary sunflower hulls with coal. The objectives are to identify feed-handling and fireside issues regarding the cofiring of sunflower hulls, determine the most cost-effective choice of additional equipment to mitigate feed-handling and combustion problems, and design a system that minimizes the disruption of the current steam plant workflow.

\section{Scope of Work}

This first part of this task was accomplished by performing both on-site visits and phone interviews with companies currently firing 100\% sunflower hulls for cogeneration and steam production. This allowed us to benefit from prior knowledge and the experience of other companies that have been successfully combusting sunflower hulls. The interviews illustrated several feed and combustion problems specific to the firing of sunflower hulls, along with the solutions the companies took to mitigate or eliminate the problems.

The second part of this task was to perform metering, mixing, feeding, and combustion screening tests at the UND steam plant facility to identify issues specific to the equipment currently installed at the facility. The UND steam plant facility provided the time and labor to 
perform several feed-handling and combustion screening tests in its facility. The primary goals of the tests were to identify problems with converting the steam plant to a cofiring facility and determine the minimum amount of equipment modifications or new equipment purchases required to enable a cofiring scheme. At this stage, we were not concerned with optimizing performance of the system.

\section{Prior Knowledge}

A site visit was conducted November 22, 2000, with Northern Sun Inc., a sunflowercrushing plant owned by $\mathrm{ADM}$, to see and discuss its cogeneration operation. ADM is successfully firing $100 \%$ sunflower hulls in an air-assisted moving-grate stoker, similar to the boilers used at the UND steam plant facility. Its peak electrical output is $6 \mathrm{MW}$ using both condensing and back-pressure turbines. The system, which was installed in 1984, faced many challenges prior to successful operation. Off-the-shelf equipment for burning biomass was lacking, so much of the equipment for this plant was modified or custom-designed in order to have a working system. This system is a one-man operation, with the soot blown once per shift and the tubes cleaned every 6 months for maintenance.

A phone interview was performed with Cargill Inc. Cargill fires 100\% sunflower hulls to generate steam to offset operational costs. Cargill uses a gravity-fed, moving grate stoker boiler that generates a steam pressure of $150 \mathrm{psi}$. The Cargill sunflower-crushing plant generates 100 tons/day of sunflower hulls and burns 40 tons/day. The rest are sold as livestock bedding.

Several issues were common to both plants concerning the firing of sunflower hulls. Feed issues that were mentioned were related primarily to the low weight and higher volatility of the sunflower hulls. Both vertical and horizontal segregation in the storage bunker was a concern. Sunflower hull dust tended to rise to the top of the storage bunker. If the storage bunker were not recharged before reaching the end of the storage bunker batch, then a large quantity of very fine dust would be fed into the boiler, causing feed problems. Fires in the feed were also an issue that required equipment modifications. The trough that housed the augers had to be modified to reduce the air gap above the sunflower hulls. Prior to this modification, fires would burn through the feed system to the storage bunker. The low weight of the sunflower hulls required air to assist injection into the boilers.

The fireside issues related to the burning of sunflower hulls were a hot grate, higher opacity, and clinkers in the bottom ash. The low ash content of sunflower hulls drastically reduced the amount of ash on the grate, which increased the grate temperature. The low weight of the sunflower hulls tended to cause the sunflower hulls to burn in suspension. The sunflower hulls also generated much finer fly ash, which increased opacity significantly. Both of these problems were addressed by increasing the overfire air in the boiler, allowing for conditions that increased the residence time of the sunflower hulls in the combustion zone. It also decreased the amount of fly ash generated. Also, ash chemistry of the sunflower hulls tended to increase the number and size of the clinkers in the bottom ash relative to coal. This was addressed by installing clinker breakers for the bottom ash.

These issues acted as the starting point in determining what to observe during the feedhandling and combustion tests at the steam plant. On top of these specific issues, the feed- 
handling and combustion tests were meant to identify any issues specific to the equipment used in the steam plant. A summary of the prior knowledge as applied to cofiring within the UND steam plant facility is given as follows:

- Storage bunker segregation may occur with the sunflower hulls and the coal because of their different sizes and density. If so, would this cause hot spots or uneven burning in the boilers?

- Without an air-assisted stoker, will the feed segregate within the boiler, causing hot spots or uneven burning?

- At approximately a $25 \%$ cofiring ratio, will fire in the feed system be a problem?

- A higher cofiring rate will probably require a slower grate speed to maintain a sufficient ash layer on the grate.

- Opacity will probably be a problem, but can it be mitigated by increasing the overfire air?

- Increased clinkers may be a problem in the bottom ash. This may require the investment of clinker breakers for cofiring with sunflower hulls. Long-term combustion tests will have to be performed to determine if this will be the case.

\section{Feed-Handling and Combustion Tests}

The stages in the feed-handling and combustion system which were addressed in these screening tests were metering, mixing, conveying the blended feed to the boilers, and combusting the blended feed. These screening tests were used to identify potential problems and equipment needs to enable the plant to cofire sunflower hulls with coal. As such, data taken were not used to optimize the system for cofiring, but were used primarily to identify potential problems and general trends.

\section{Facilities/Description of Layout}

UND is a coeducational, state-supported institution located in Grand Forks, North Dakota. UND enrolls approximately 10,300 students and is the largest institution of higher education in North Dakota, South Dakota, Montana, and western Minnesota. Within the University, the facilities department is responsible for utility management for the entire campus. Currently, UND fires 45,000 tons/year of subbituminous coal to provide steam to a campus containing over 200 buildings with a combined square footage of 5,124,487. Saturated steam at 130 psig is provided year-round. In the summer months, steam is used to create hot and chilled water. The UND's steam plant consists of three water tube spreader stoker boilers and four gas-/oil-fired boilers. The coal-fired boilers are each rated for $13,000 \mathrm{lb} / \mathrm{hr}$ of coal, and each has a capacity of 65,000 to $75,000 \mathrm{lb} / \mathrm{hr}$ of steam. Three of the gas-/oil-fired units are rated for $60,000 \mathrm{lb} / \mathrm{hr}$ of steam, and one is rated at 30,000 lb/hr. The coal-fired boilers were manufactured by Williams Brothers, Babcock \& Wilcox, and Zurn Industries and were installed in 1952, 1966, and 1978, respectively. Emissions are controlled by separate multicyclone units in parallel with a side 
stream baghouse. The subbituminous coal is a $2 \times 1 / 4$ stoker coal @ 8500 Btu/lb, 0.6\% sulfur, $8.3 \%$ ash, and 25\% moisture. The University had switched from North Dakota lignite to subbituminous. The subbituminous coal results in lower maintenance and is within permit limitations for sulfur, which substantiates a lower overall cost despite the higher purchase price.

The coal-fired boilers are fed by a primary and auxiliary auger feed system. For the primary feed system, a deep pit is located in the coal shed adjacent to the steam plant building. The deep pit is flood fed with coal from railcars. The coal is transported to a bucket elevator via a conveyor belt and then fed to the appropriate boiler storage bunker through an auger feed system. The auxiliary feed system uses a shallow pit adjacent to the primary deep pit. The shallow pit uses three parallel augers to feed a transverse auger that feeds another bucket elevator. The bucket elevator then dumps the coal onto the auger feed system in the steam plant building.

\section{Test Procedures}

Two metering and mixing methods were tested. The first method used a payloader to premix the sunflower hulls with the coal and then store the blended feed in the coal storage shed for the first combustion run (Figure 2-1). The mix ratio was approximately $23 \%$ by weight sunflower hulls, which equated to a bucket ratio of 3:2 sunflower hulls to coal. Both the coal and sunflower hulls were spread on the ground in layers, and the payloader used to mix the batch. Approximately 25 tons of blended feed was produced this way for the first test.

The second method used the secondary auger system at the steam plant facility to mix the sunflower hulls and the coal, in-line, with the feed system augers (Figure 2-2). The auxiliary feed system at the steam plant uses a shallow coal pit consisting of three input screws that feed a bucket elevator via a conveyor belt, which in turn feeds the boilers through a series of feed system augers. The shallow pit is located in the coal shed. When the auxiliary system is used, the shallow pit is usually flood fed with coal. For this test, two of the screws in the pit were flood fed with sunflower hulls and one screw was flood fed with coal. This equated to a mix ratio of approximately $25 \%-29 \%$ sunflower hulls by weight. The coal and the sunflower hulls were then mixed by the feed system augers in transport. In a typical system, the blended feed would go directly to the storage bunkers, but for this test, the blended feed was dumped back into the coal storage shed for the second combustion run.

The combustion runs were performed on two different boilers. Boiler 3 was used for the first combustion run using the feed mixed via the payloader. This boiler uses overthrow stokers, with the overfire air nozzles located next to (as opposed to above) the stokers. The second combustion run was performed in Boiler 5 with the feed mixed in-line with the feed system augers. This is a newer boiler with the overfire air nozzles located approximately 2 feet above the overthrow stokers. 


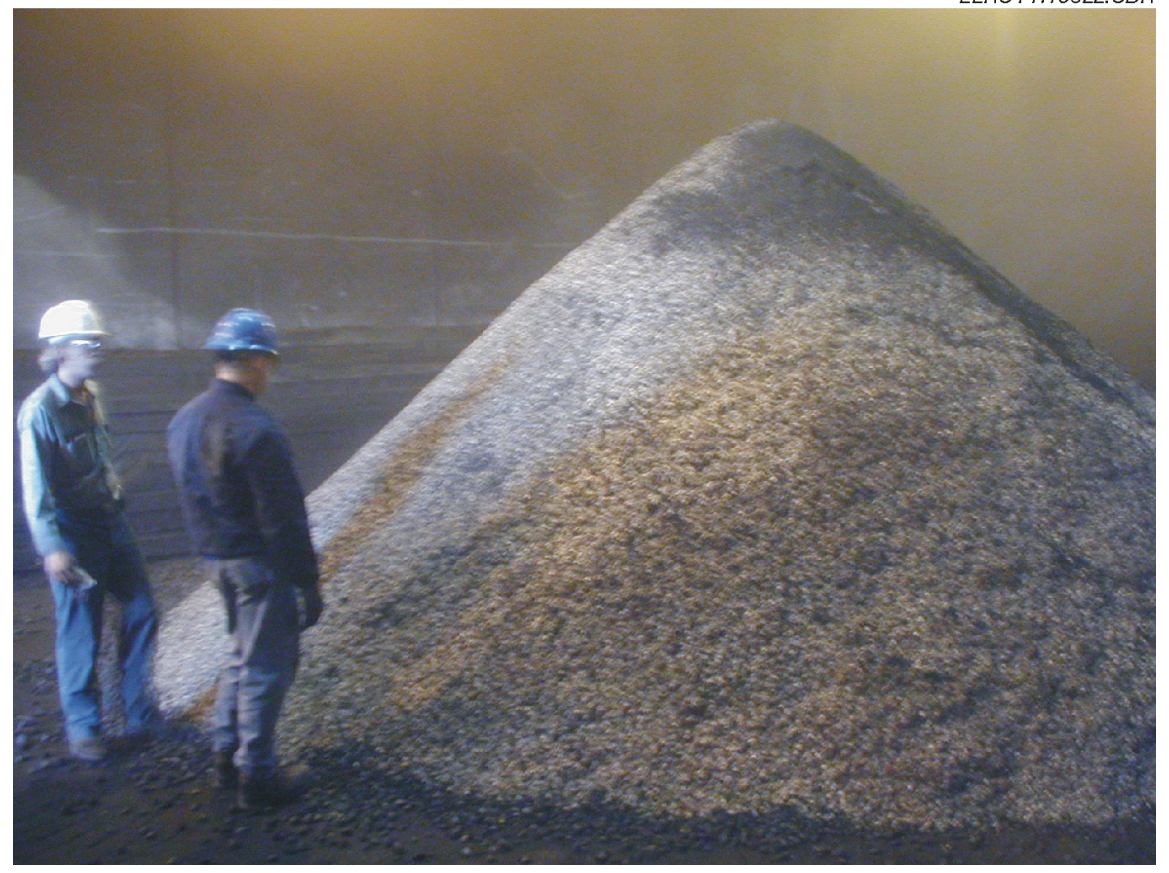

Figure 2-1. Result of blended fuel.

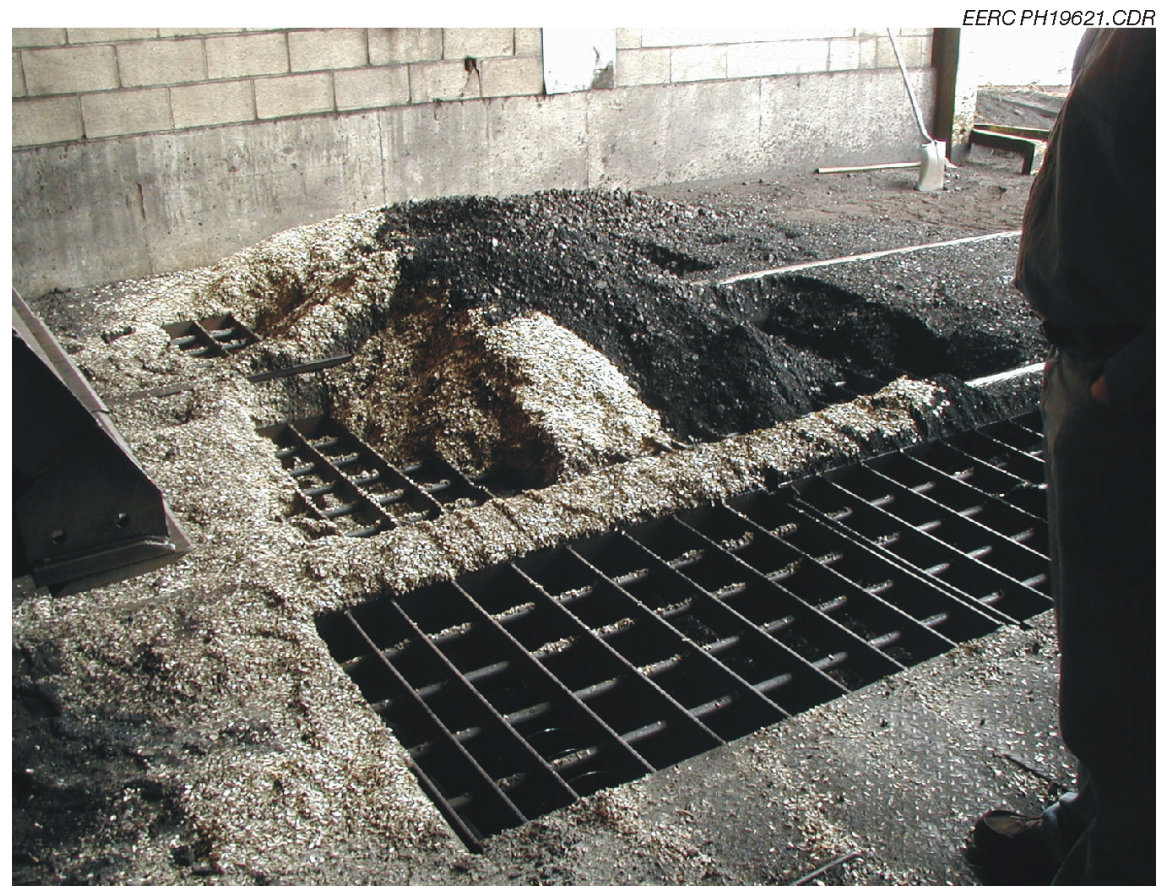

Figure 2-2. Blending of sunflower hulls and coal. 
The test procedure for the combustion runs consisted of taking baseline data on coal and then comparing it with the results of a combustion run with the blended feed on the same boiler, under identical boiler settings and load settings. For the combustion runs, the boiler settings were maintained at the typical coal settings. Since the boiler settings were not optimized for the blended feed, the comparisons were made primarily to determine general trends and ensure that the performance data for the blended feed were reasonably close to the performance of the baseline coal.

For both combustion runs, the boilers were operated at full load $(60,000 \mathrm{lb} / \mathrm{hr}$ steam), half load (30,000 lb/hr steam), and one-quarter load $(15,000 \mathrm{lb} / \mathrm{hr}$ steam) for approximately 2 hours at each load setting. Bottom ash, particulate ash off the multicyclone, baghouse ash, and fly ash samples were taken at each load setting on both boilers approximately 1 hour after each load setting was attained. On Boiler 3, emissions data were taken with a Teledyne stack analyzer at the smokestack. These readings provided measurements on stack temperature, $\mathrm{O}_{2}, \mathrm{CO}, \mathrm{CO}_{2}, \mathrm{NO}_{\mathrm{x}}$ and $\mathrm{SO}_{\mathrm{x}}$. This was done for both the baseline coal and the blended feed. Emission data were not taken for the second combustion run on Boiler 5 because of Teledyne sensor failure. The opacity was documented at each load setting on both boilers using EPA Method 9. The input and output variables listed in Table 2-1 were recorded automatically every 10 minutes at the computer control consol for the steam plant. A visual inspection of the firebox was performed every 30 minutes to determine if there were any irregularities in the feedstock burn such as non-uniform burning.

In addition, the feed flow was observed to determine if excessive segregation occurred in the storage bunker and at the inlet to the stokers at Boiler 3. The inlet to the stokers at Boiler 5 is covered, so a visual assessment was not possible on that boiler. A cold feed test in Boiler 3 was also performed with the blended feed to determine if the sunflower hulls segregated from the coal after being injected into the firebox without an air assist. Although segregation was expected at both points, our objective was to determine if the segregation was detrimental to boiler performance.

\section{Results}

During the first combustion run on Boiler 3 with the blended feed, several feed-handling and control problems occurred. The blended feed caused excessive dust control problems during conveyance to the storage bunker. The amount of dust exceeded what would have been expected for firing either the sunflower hulls or the coal alone (Figure 2-3). This posed both a health hazard and possibly an explosion hazard. Once in the storage bunker, horizontal segregation became evident, with the larger chunks of coal migrating to the outside edge of the pile and the fines sifting through the center. Excessive segregation was also evident at the inlet to the stoker (Figure 2-4). This caused control problems at full load. The fines initially sifted into the firebox, even with the feed rate backed completely off. This condition occurred for the first 2 hours. After the first couple of hours, the feed rate came under control. 


\section{Table 2-1. The Input and Output Parameters Monitored for the Combustion Runs}

\begin{tabular}{|c|c|c|}
\hline No. & Item & Description \\
\hline 1 & Air Flow & Forced draft air under the grate \\
\hline 2 & Bag Diff. Pressure & Diff. pressure across tube sheet in the sidestream baghouse \\
\hline 3 & Bag Inlet Pressure & Inlet pressure in the sidestream baghouse \\
\hline 4 & Bag Inlet Temp. & Inlet temperature in the sidestream baghouse \\
\hline 5 & Bag Outlet Temp. & Outlet temperature in the sidestream baghouse \\
\hline 6 & Bag Outlet Pressure & Outlet pressure in the sidestream baghouse \\
\hline 7 & Bias Station & Bias signal to forced-draft fan for airflow \\
\hline 8 & Boiler Master & Master controller for all air and feed inputs \\
\hline 9 & Comb. Air Temp. In & Temperature of forced draft entering the preheater \\
\hline 10 & Comb. Air Temp. Out & Temperature of forced draft leaving the preheater \\
\hline 11 & Draft & Differential pressure between the firebox and atmosphere \\
\hline 12 & Efficiency & Calculation of output/input \\
\hline 13 & FD Bias Station & Controller for the forced-draft fan bias signal \\
\hline 14 & FD Bias Value & Bias set point \\
\hline 15 & FD Station & Forced-draft fan controllers \\
\hline 16 & Flue Gas Temp. In & Temperature of the flue gas entering the preheater \\
\hline 17 & Flue Gas Temp. Out & Temperature of the flue gas leaving the preheater \\
\hline 18 & Drum Pressure & Steam pressure in the drum \\
\hline 19 & ID Station & Controller for the draft air into the firebox \\
\hline 20 & OFA Fire Station & Controller for the overfire air approx. $3 \mathrm{ft}$ above the grate \\
\hline 21 & Excess Oxygen & $\%$ oxygen in the boiler \\
\hline 22 & Oxygen Setpoint & Oxygen set point in the boiler \\
\hline 23 & Oxygen Station & Controller for the oxygen boiler setting \\
\hline 24 & Preheater Bypass Station & Controller to bypass preheater until input gas temperatures reach $300^{\circ} \mathrm{F}$ \\
\hline 25 & Preheater dP & Differential pressure across tube sheet in the preheater \\
\hline 26 & Particulate dP & Differential pressure in the multicyclone behind the boiler \\
\hline 27 & Particulate Temp. & Temperature in the multicyclone behind the boiler \\
\hline 28 & Stoker Station & Controller for the fuel feed \\
\hline 29 & Steam Flow & Measures the steam flow \\
\hline 30 & Steam Pressure & Measures the steam pressure \\
\hline 31 & Steam Temp. & Measures the steam temperature \\
\hline
\end{tabular}




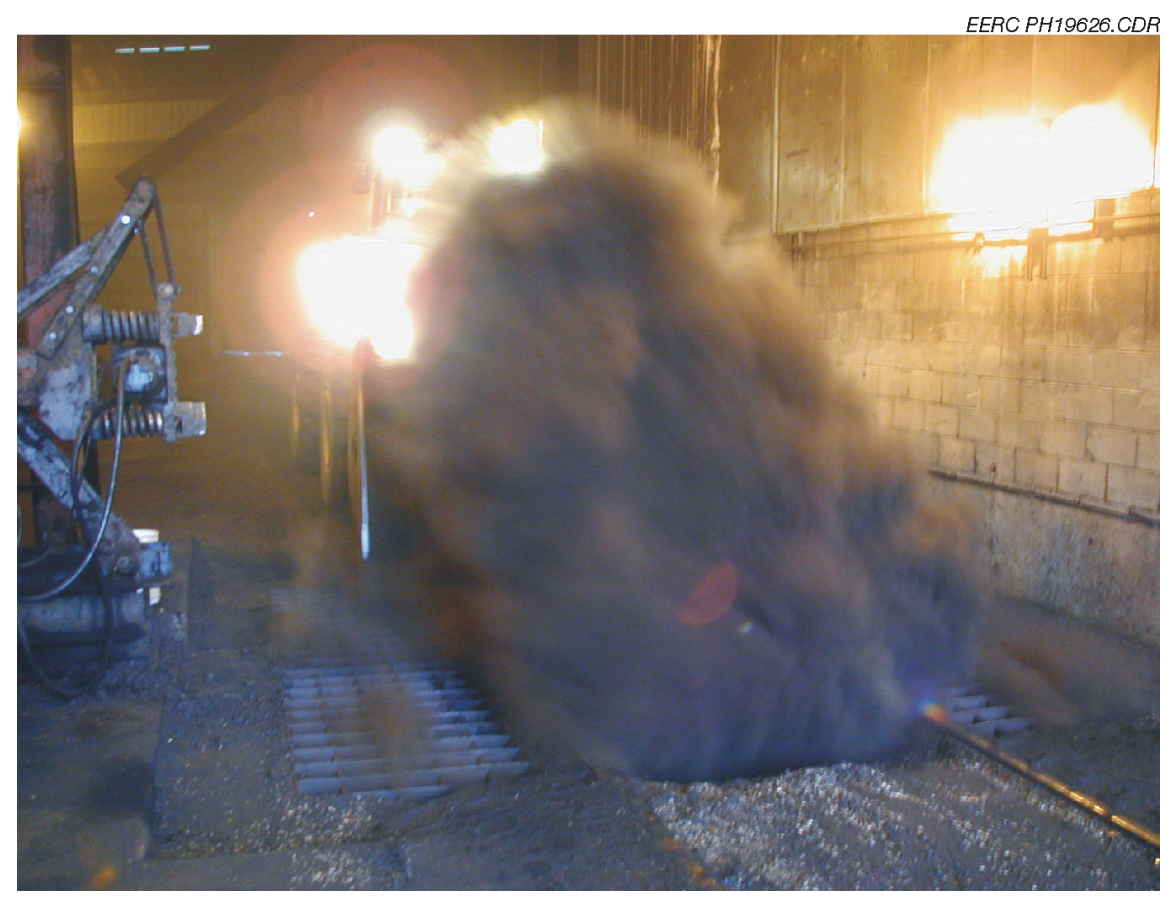

Figure 2-3. Example of loading fuel into the system and potential dust issues.

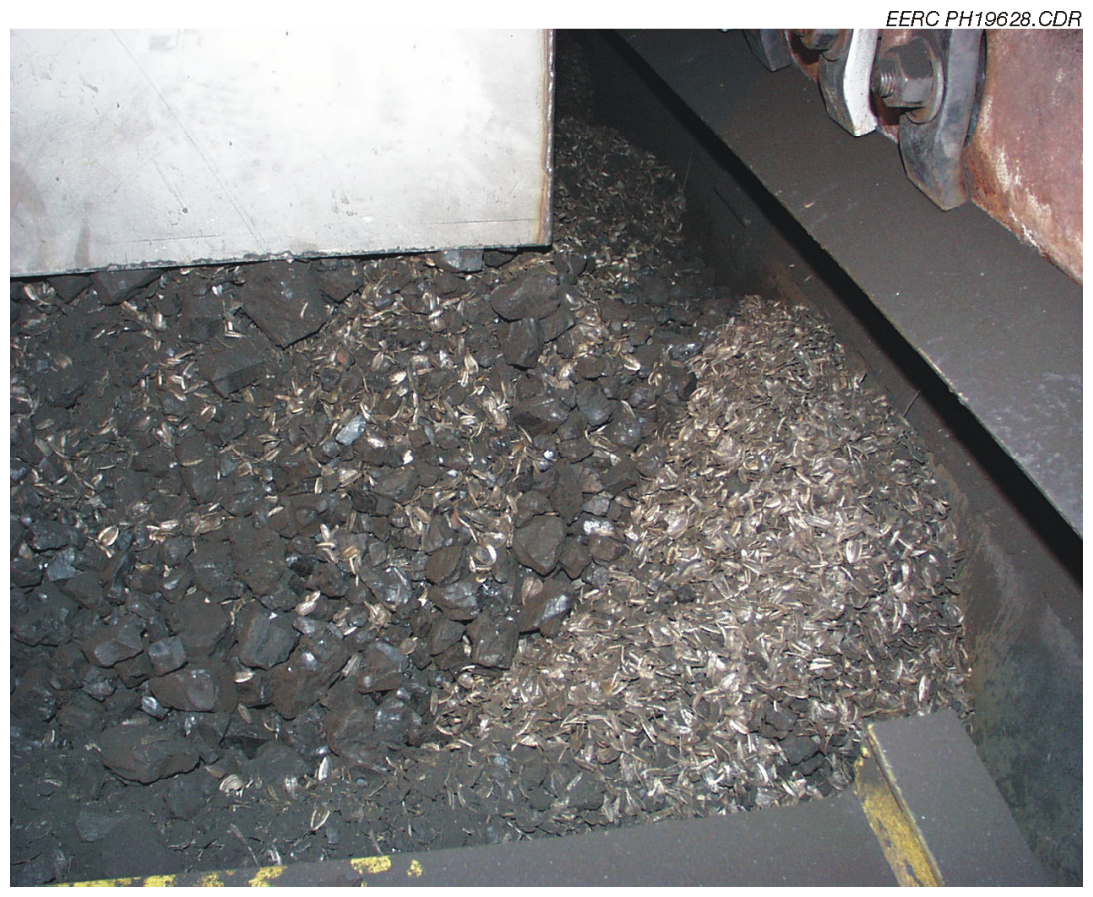

Figure 2-4. Example of segregation issue at stoker inlet on Boiler 3. 
The following is a summary of the observational results for the first combustion run in Boiler 3, using the feed premixed with the payloader:

- Excessive brown dust posed both a health hazard and explosion hazard for plant personnel.

- Excessive segregation in the storage bunker caused initial feed control problems because of fines sifting into the firebox, even with the feed rate backed completely off.

- No hot spots were observed in the firebox.

- No clinkers were found in the bottom ash.

- Opacity doubled from $10 \%-15 \%$ for the baseline coal, to $15 \%-25 \%$ for the blended feed.

A sieve analysis on the blended feed indicated that more than $50 \%$ of the feed were fines less than $1 / 4$ inches. Retrospect analysis of the run concluded that premixing with the payloader caused excessive coal attrition. This was suspected as the primary cause for the higher opacity, excessive segregation, and feed control problems. It was postulated that the fines were sucked into the firebox at full load, even with the feed rate turned off. It was also postulated that the coal fines were carried out of the firebox before complete combustion, contributing to the increase in opacity. This condition may have been exacerbated by the location of the overfire air nozzles, which are at the same elevation as the stokers.

A cold feed test was subsequently performed on Boiler 3 with the blended feed. As expected, without an air assist, the lighter sunflower hulls fluttered approximately 4 feet from the front wall while the coal chunks were thrown to the back wall of the firebox (Figure 2-5). Although segregation was readily apparent during the cold feed test, no hot spots were observed during the combustion runs, indicating that convective currents in the firebox during combustion may have carried the sunflower hulls throughout the firebox. The next combustion run on Boiler 5 confirmed that the sunflower hulls were burning in suspension throughout the firebox, while the coal chunks were burning on the grate.

In addition to segregation in the firebox, it was found that sunflower hulls sifted into the firebox at a very low rate when the feed rate was turned off. This was specific to the stokers on Boiler 3.

A summary of the findings for the cold feed test are as follows:

- The lighter sunflower hulls do segregate in the firebox, but during a combustion run they may be carried throughout the firebox by convective currents.

- The stoker clearances in Boiler 3 were loose enough to allow some sifting of sunflower hulls into the firebox with the feed rate backed off completely. 


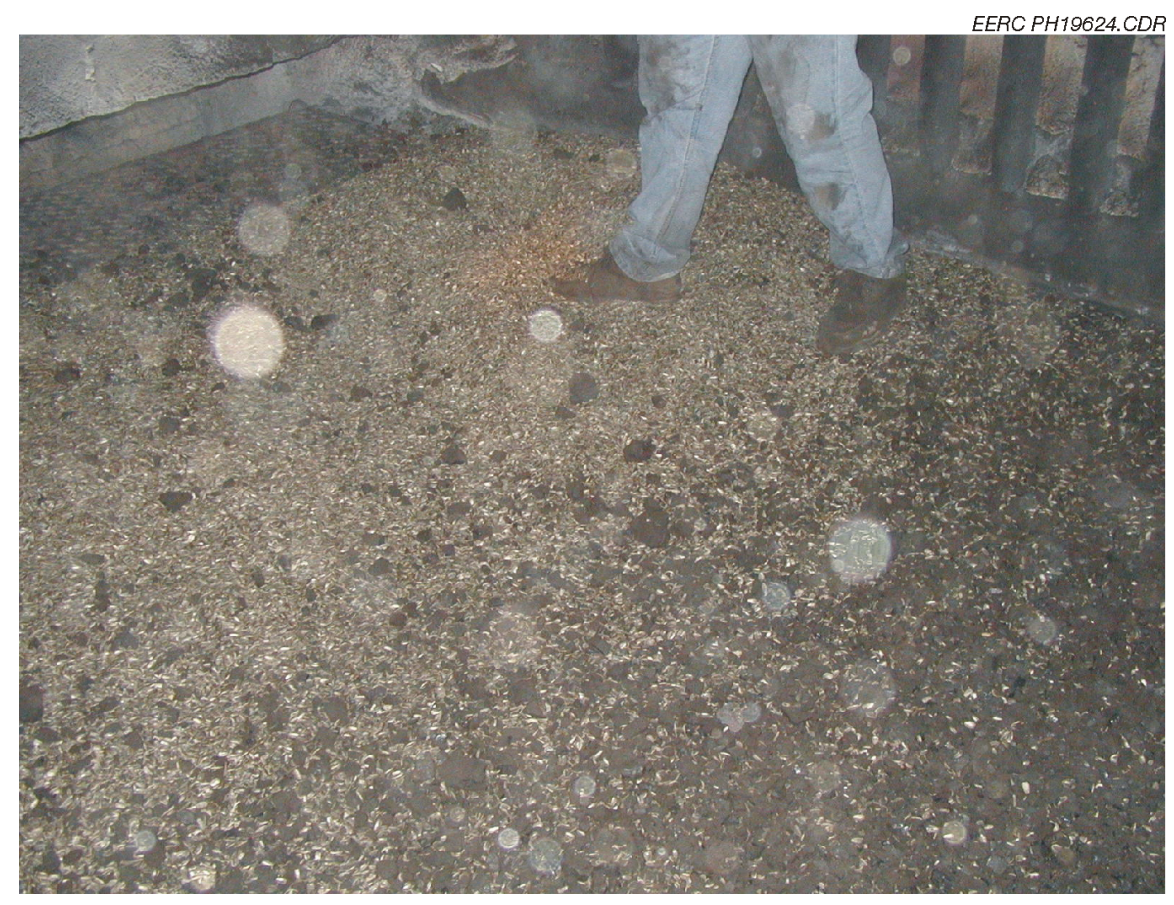

Figure 2-5. Cold test Boiler 3 - hulls at stoker end of grate, coal at opposite end.

The second combustion run was performed on Boiler 5 using the feed mixed in-line with the feed system augers. During the mixing tests, it was determined that the feed system augers did a very good job at mixing the sunflower hulls with the coal (Figure 2-6). Dust was still a potential hazard, but in a typical operation, the feed system would be enclosed and the blended feed would go directly to the storage bunkers. This would ensure minimal attrition of the coal and minimal dust control problems. Visual observation of the storage bunker and fuel feed discharge prior to the stokers showed minimal segregation (Figure 2-7). The overfire air in Boiler 5 is located above the stokers, but was maintained at the typical flow rate for coal, about $5 \%$. When the boiler is optimized for cofiring, we expect the overfire air to be increased to $40 \%$.

During the combustion run, no unusual control problems occurred in Boiler 5 using the feed mixed in-line with the feed system augers. Visual observation of the firebox confirmed that the sunflower hulls were burning in suspension throughout the firebox and the coal was burning on the grate (Figure 2-8). Feed control was maintained throughout the run. Opacity decreased slightly, but the color of the smokestack plume turned a light brown. With further optimization of the overfire air rate, it may be possible to decrease he opacity below current levels.

A summary of the observational findings for the second combustion run is as follows:

- Mixing the feed in-line with the feed system augers decreased coal attrition and potential dust problems.

- Control was maintained throughout the run. 
- The sunflower hulls burned in suspension throughout the firebox.

- The coal chunks burned on the grate as normal. This would imply that a decrease in grate speed proportional to the ratio of biomass in the feed is necessary to maintain an adequate ash layer on the grate.

- No clinkers were found in the bottom ash.

- Opacity remained constant or decreased slightly.

Overall, the feed-handling and combustion tests were successful at highlighting issues that must be addressed with the current equipment the UND steam plant facility has installed. It was found that the ideal mixing method is to mix the coal and the biomass with the feed system augers on their way to the storage bunkers. This caused less coal attrition, a lower potential dust hazard, and minimal disruption to the current steam plant workflow relative to premixing the biomass and coal. Dust was found to be a potential hazard that must be addressed if cofiring is adopted at the steam plant. The dust was only found to be a problem during and after mixing the sunflower hulls and the coal. The amount of dust produced exceeded what would have been expected for either the coal or the sunflower hulls fired alone. This would require that the feed system be adequately enclosed.

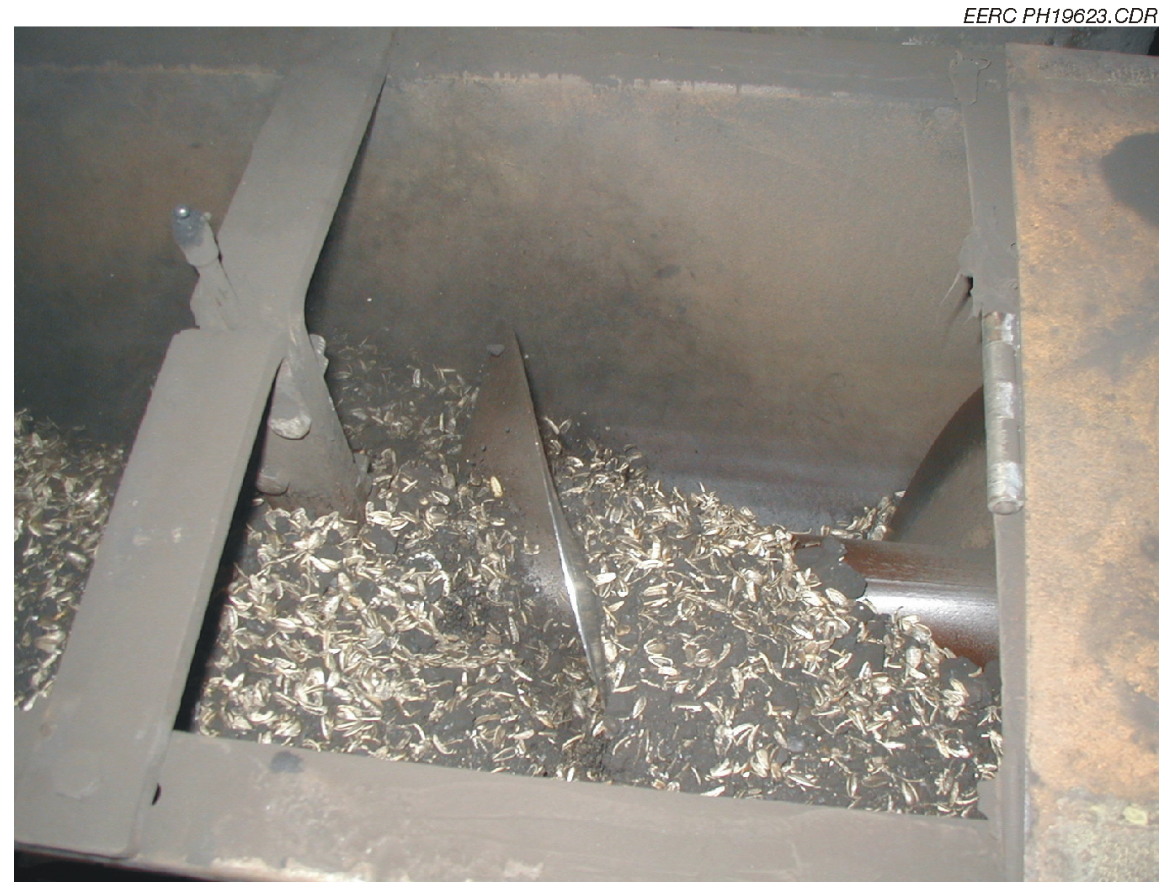

Figure 2-6. Mixing in auger system. 


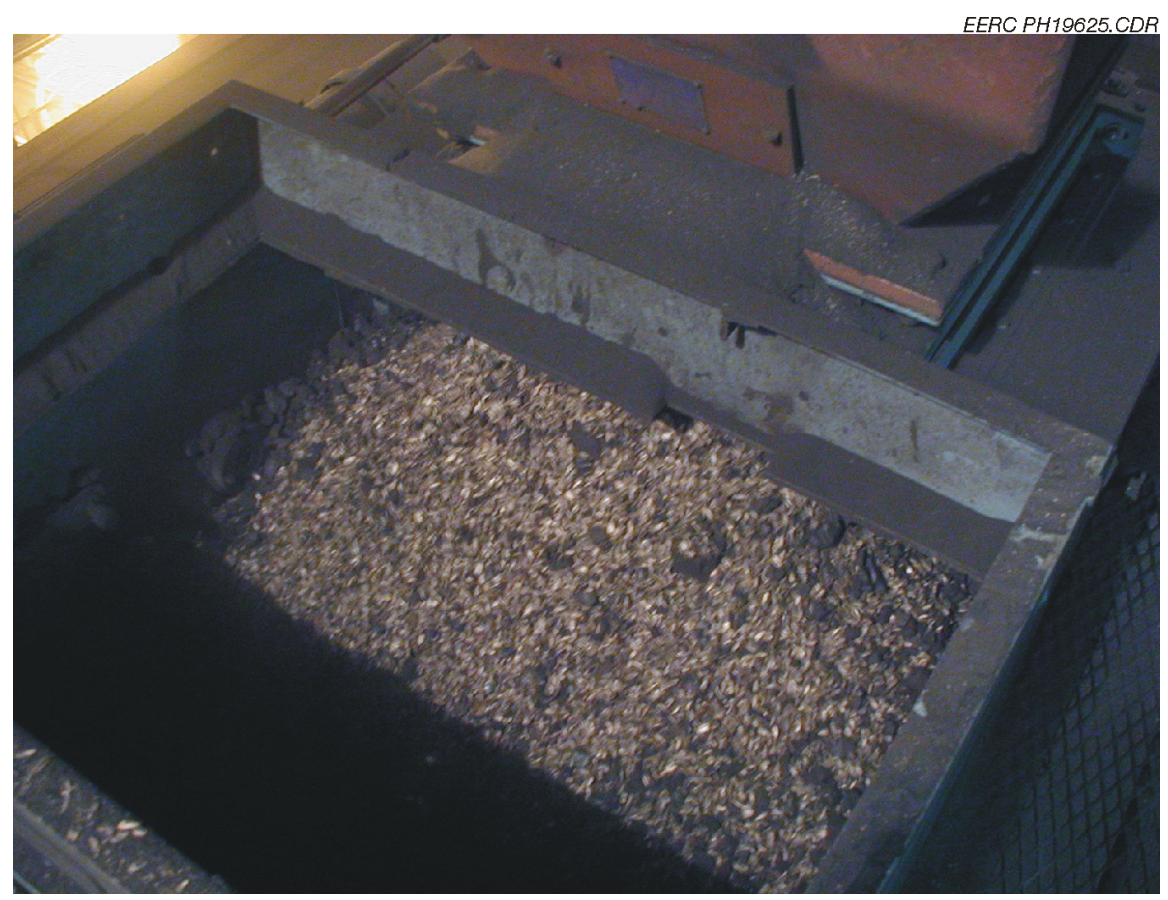

Figure 2-7. Fuel feed at discharge of bunker on Boiler 5 prior to stokers.

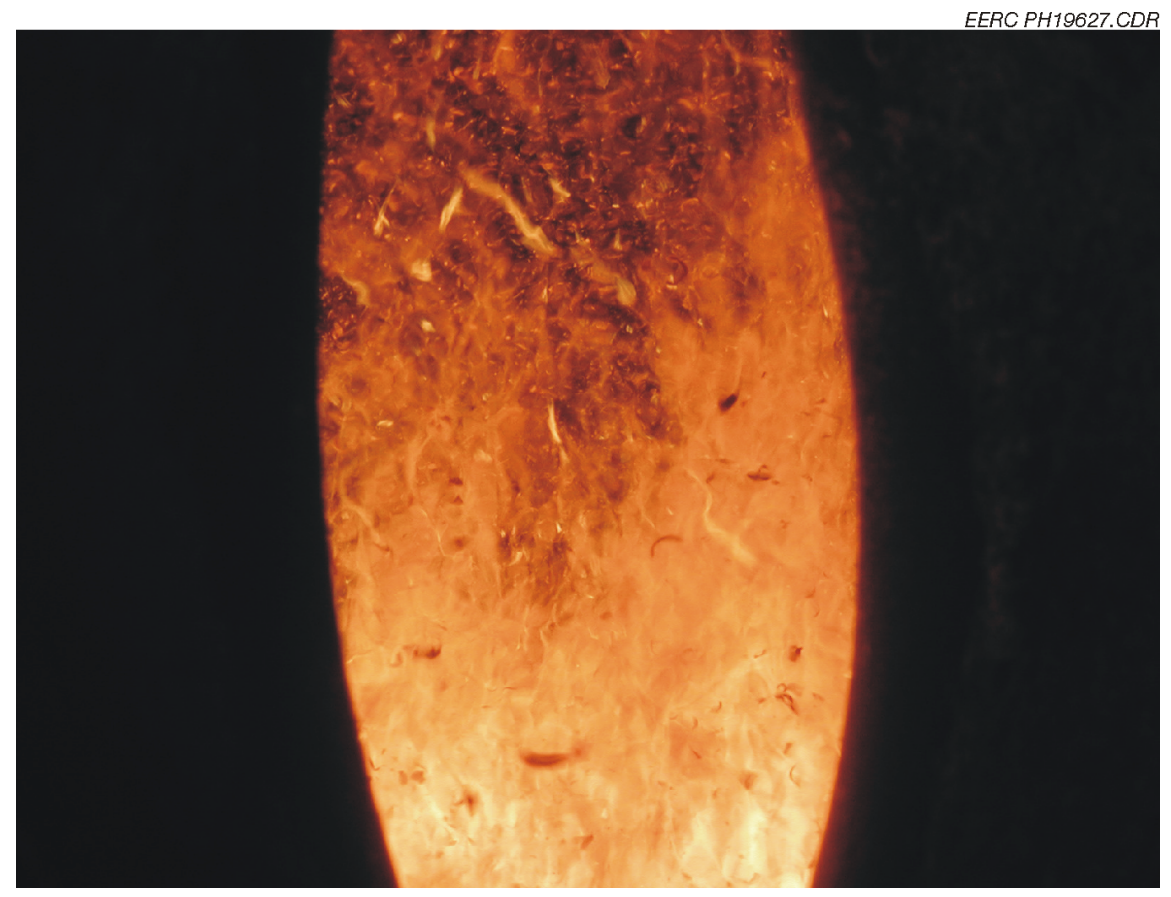

Figure 2-8. Mid-grate inspection port on Boiler 5. Sunflower hulls are burning in suspension. 
The current stokers on Boiler 5 are adequate for cofiring sunflower hulls. Although firebox segregation does occur, the convective currents in the firebox during combustion provide the means of distributing the sunflower hulls. This means that an air-assist is not required to cofire sunflower hulls. The stokers on Boiler 3 may have to be replaced to allow it to cofire sunflower hulls. This has to be determined through subsequent testing. The overfire air in Boiler 5 is adequate to maintain good opacity. The overfire air nozzle configuration in Boiler 3 must be moved above the stokers for better emission control. Clinkers were not found to be a problem with these tests, but longer-term testing is needed. The grate speed must be slowed during cofiring.

From a maintenance perspective, prior knowledge would dictate that the steam plant sootblow at least once a day, if not once a shift. The tubes should be cleaned every 6 months. These requirements should not be a problem since the steam plant facility does not typically run all year-round with all of their boilers.

From an equipment perspective, it was found that no additional equipment modifications or purchases were required inside the steam plant to cofire sunflower hulls in Boiler 5. Boiler 7 is similar to Boiler 5, so it is expected to follow suite. Boiler 3 must be modified to allow it to cofire sunflower hulls. The stokers must be tested to ensure that they can adequately feed the smaller and lighter sunflower hulls. The overfire air nozzles in Boiler 3 must be moved above the stokers. Outside of fully enclosing the feed system, no additional modifications are required to allow it to cofire sunflower hulls. The greatest savings in equipment expenditures occurs by mixing the sunflower hulls and coal in-line with the feed system augers. This eliminates the need to purchase additional mixing equipment, but necessitates the need to provide an adequate metering system at the input to the feed system.

\section{Data Analysis}

The scopes of these tests were not to optimize the system for cofiring, but to identify issues or problems that must be addressed to enable a cofiring scheme. As such, the data were taken primarily to analyze general trends and identify any abnormal conditions.

Table 2-2 shows the opacity measurements at the smokestacks for both combustion runs. The opacity measurement is taken at the common smokestack to Boilers 3, 5, and 7, so they represent the average opacity for all three boilers at any particular time. During the first combustion run, Boilers 3, 5, and 7 were on-line, with Boiler 3 being the test boiler. During the second combustion run, Boilers 5 and 7 were on-line, with Boiler 5 being the test boiler.

For the first combustion run, the opacity increased from $5 \%-10 \%$ from the baseline coal to the blended feed. Posttest analysis determined that excessive coal fines produced during the mixing of the sunflower hulls and coal with a payloader contributed to the increase in opacity. The location of the overfire air nozzles in Boiler 3 may also have contributed to the increase in opacity. The second combustion run in Boiler 5 showed no increase in opacity. The sunflower hulls and coal were mixed in-line with the feed system augers, which produced less coal fines. 


\section{Table 2-2 Opacity (average of 24 readings)}

\begin{tabular}{cccc}
\hline \multicolumn{2}{c}{ Boiler 3 } & \multicolumn{2}{c}{ Boiler 5 } \\
Baseline Coal & Blended Feed & Baseline Coal Blended Feed \\
\hline $10 \%$ & $20 \%$ & $20 \%$ & $15 \%$ \\
$10 \%$ & $25 \%$ & $15 \%$ & $15 \%$ \\
$10 \%$ & $15 \%$ & $15 \%$ & $15 \%$ \\
$10 \%$ & $15 \%$ & $15 \%$ & $10 \%$ \\
$10 \%$ & $15 \%$ & $15 \%$ & $10 \%$ \\
$10 \%$ & $15 \%$ & $15 \%$ & $10 \%$ \\
$15 \%$ & $25 \%$ & $\mathrm{~N} / \mathrm{A}$ & $\mathrm{N} / \mathrm{A}$ \\
$15 \%$ & $25 \%$ & $\mathrm{~N} / \mathrm{A}$ & $\mathrm{N} / \mathrm{A}$ \\
$15 \%$ & $25 \%$ & $\mathrm{~N} / \mathrm{A}$ & $\mathrm{N} / \mathrm{A}$ \\
\hline
\end{tabular}

The overfire air nozzles in Boiler 5 are located above the stokers. This may have contributed to the reduction in opacity with the blended feed.

Figure 2-9 shows the emissions data for the first combustion run on Boiler 3. Because of the Teledyne sensor failure, no emissions data are available for the second combustion run on Boiler 5. The overall trend showed a decrease in both the $\mathrm{NO}_{\mathrm{x}}$ and $\mathrm{SO}_{\mathrm{x}}$ emissions. The decrease in $\mathrm{SO}_{\mathrm{x}}$ was expected because of the lower sulfur content in biomass relative to coal. The decrease in $\mathrm{NO}_{\mathrm{x}}$, however, was not expected and would be a benefit if it carried over during production runs with the blended feed. The lower $\mathrm{NO}_{\mathrm{x}}$ would imply that, although the energy released was equivalent to the baseline coal based on the performance data comparisons, the different combustion characteristics of the sunflower hulls created a more uniform temperature distribution in the firebox. The higher volatility and lower density of the sunflower hulls allowed it to burn in suspension away from the coal burning on the grate. This may have reduced peak temperatures and hot spots, thereby reducing the $\mathrm{NO}_{\mathrm{x}}$ emissions. The CO increased, indicating incomplete combustion. This was expected, given the observational findings during the combustion run on Boiler 3. Overall, the data for the blended feed was a little more erratic, illustrating the trouble we had controlling the feed rate and opacity on this combustion run.

The rest of the data analysis was performed on Boiler 5 since this combustion run represented a more probable cofiring condition should the steam plant adopt a cofiring strategy.

Figure 2-10 shows the calculated efficiency for the blended feed as compared to the baseline coal during combustion in Boiler 5. The blended feed showed slightly higher combustion efficiency than the baseline coal. Loss-on-ignition tests on the baghouse ash and the bottom ash confirmed these findings (Table 2-3). At full load, the baseline coal indicated less efficient combustion than the blended feed by approximately $5 \%$.

The baghouse ash was submitted for particle-size analysis (Figure 2-11). It was found that the particle size of the fly ash for the blended fuel was typically $10-50 \mu \mathrm{m}$, while the particle size for the baseline coal was between 50 to $100 \mu \mathrm{m}$. 

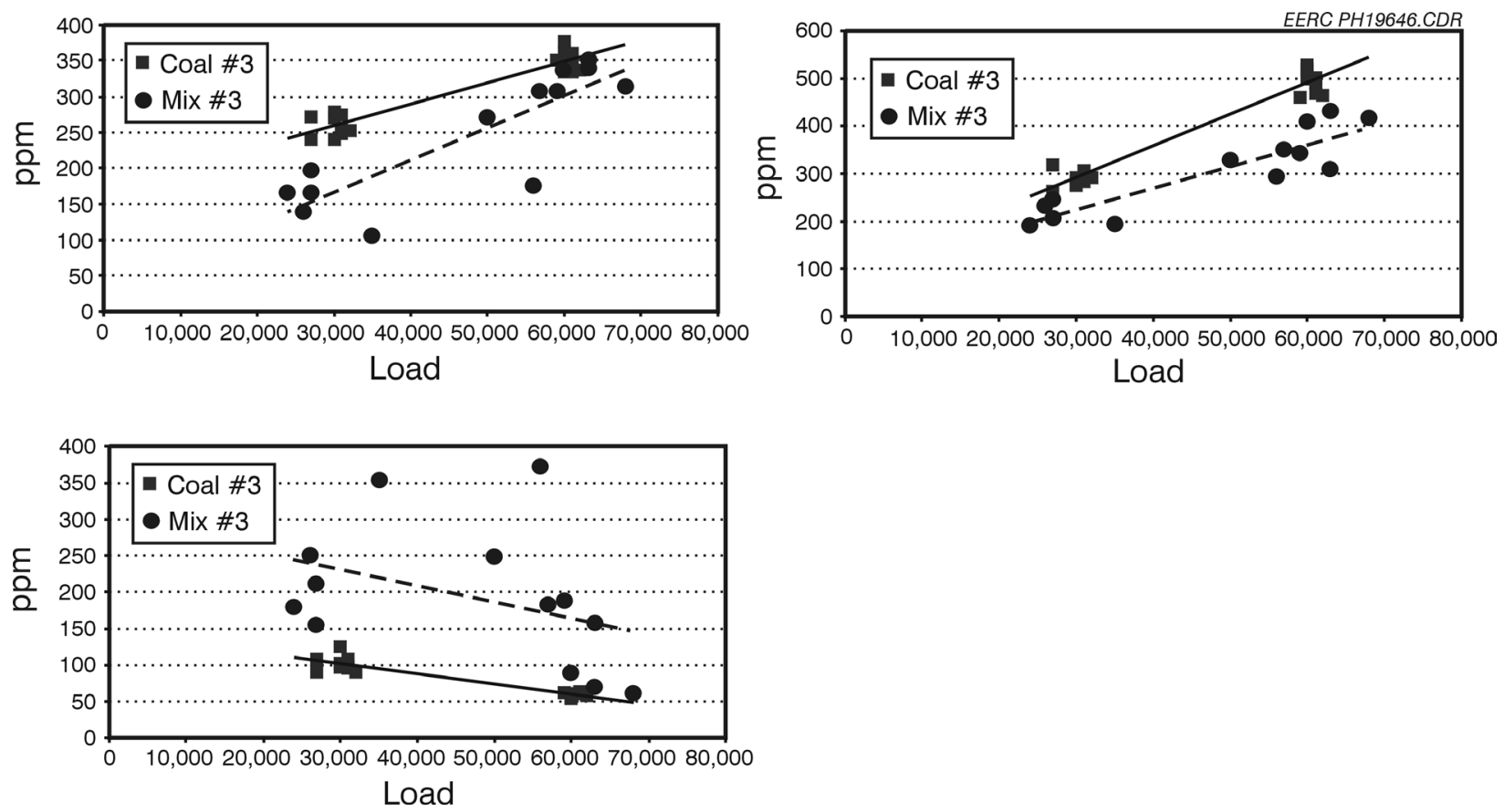

Figure 2-9. Emission data for Boiler 3.

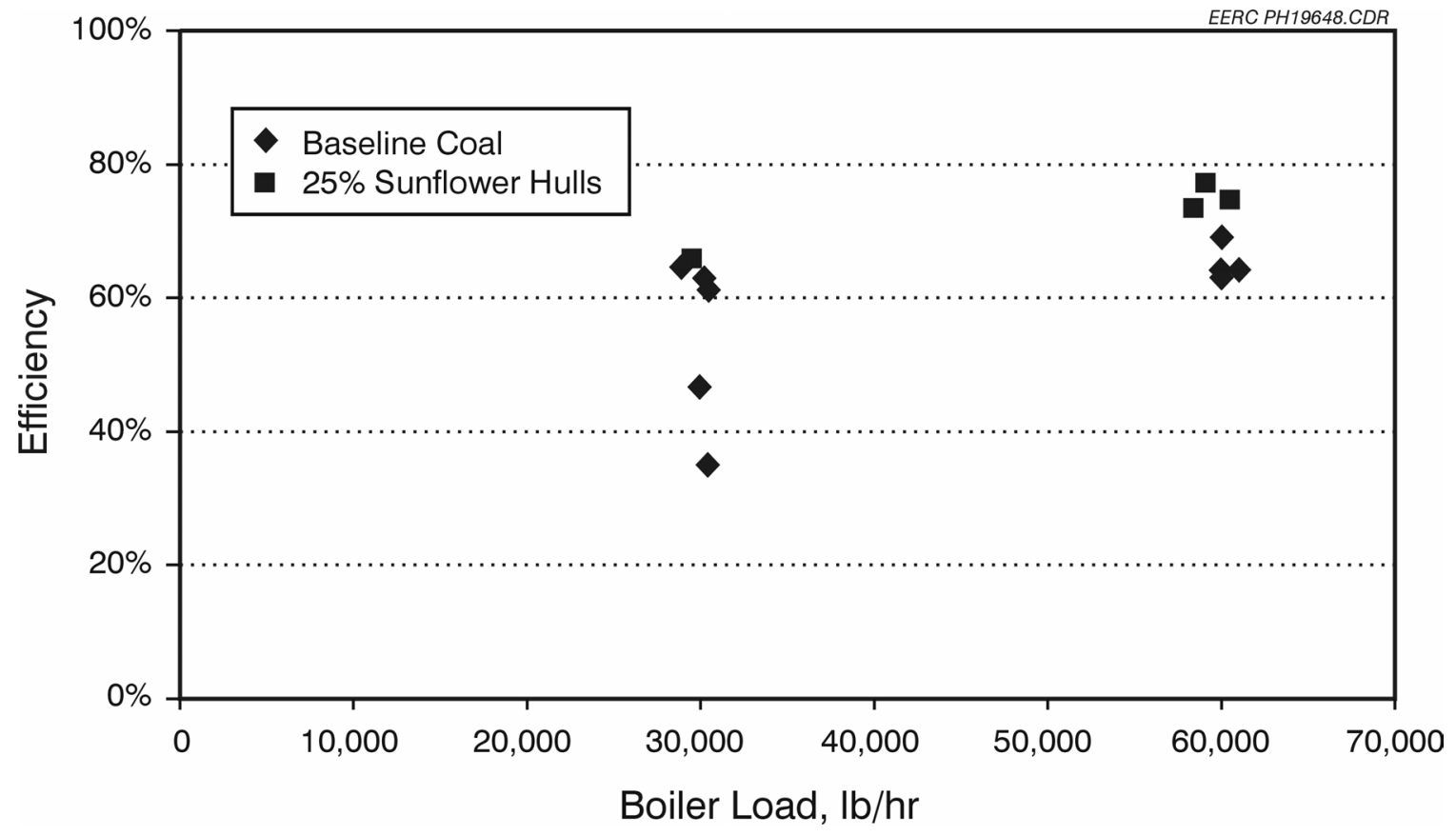

Figure 2-10. Calculated boiler efficiency. 
Table 2-3. Loss on Ignition

\begin{tabular}{lcccc}
\hline Location & Load & Coal & Blend & \% Difference \\
\hline Baghouse & Full & 17.71 & 10.31 & 7.4 \\
Bottom & Full & 7.08 & 3.05 & 4.0 \\
Baghouse & Half & 11.98 & 14.28 & -2.3 \\
Bottom & Half & 3.35 & 2.22 & 1.1 \\
& & & Average & 2.6 \\
\hline
\end{tabular}

The pressure drops, flue gas temperature, oxygen percentage, and steam header pressure were analyzed to determine if there were any significant differences between the blended feed and the baseline coal. It was determined that no discernible differences in these parameters could be detected between the baseline coal and the blended feed (Figure 2-12).

\section{Conclusions}

Overall, the blended feed tended to perform slightly better than the baseline coal with respect to emissions and combustion efficiency. Performance data indicated no significant differences in the test conditions between both fuels. Particle size of the fly ash for the blended fuel was found to be much lower than the baseline coal and may have to be addressed at a later date. A summary of the observations and conclusions are given as follows:

- Steady steam - steady production at all load settings

- Firebox pressure - maintained negative draft

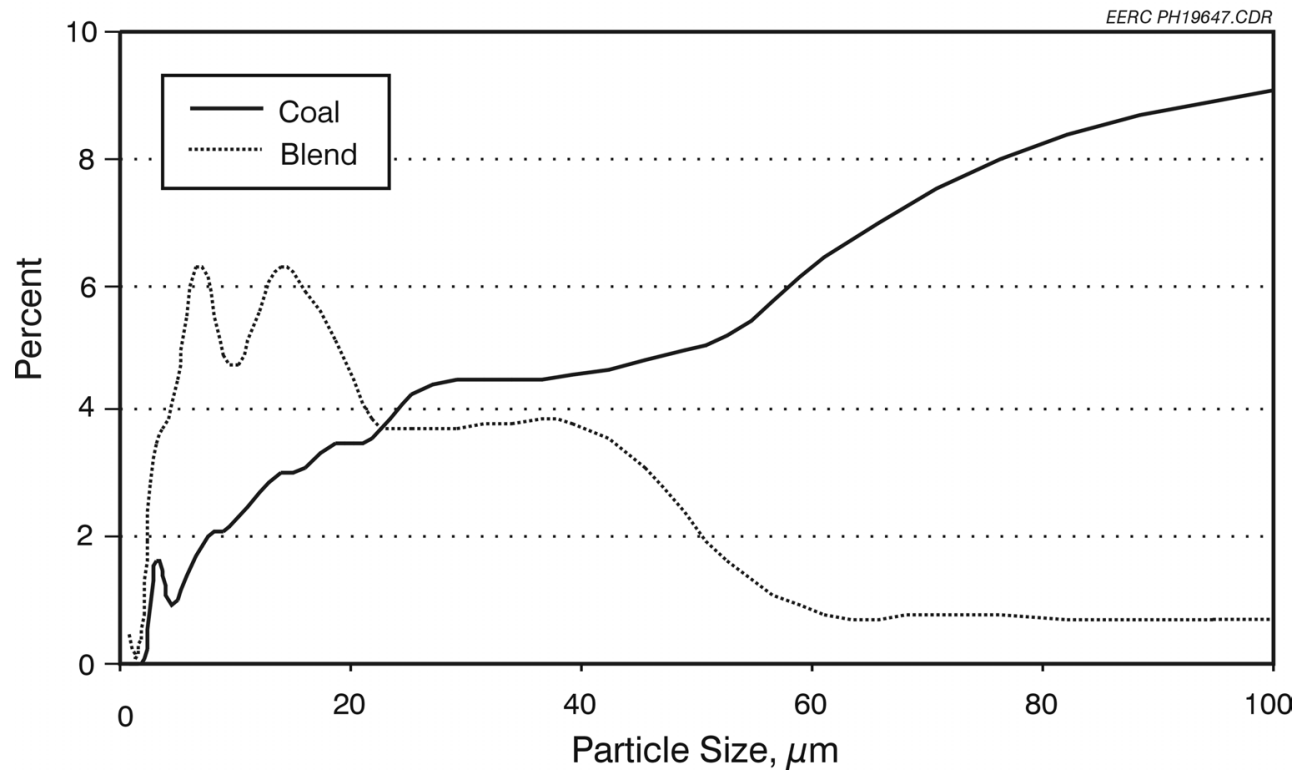

Figure 2-11. Baghouse particle-size distribution. 

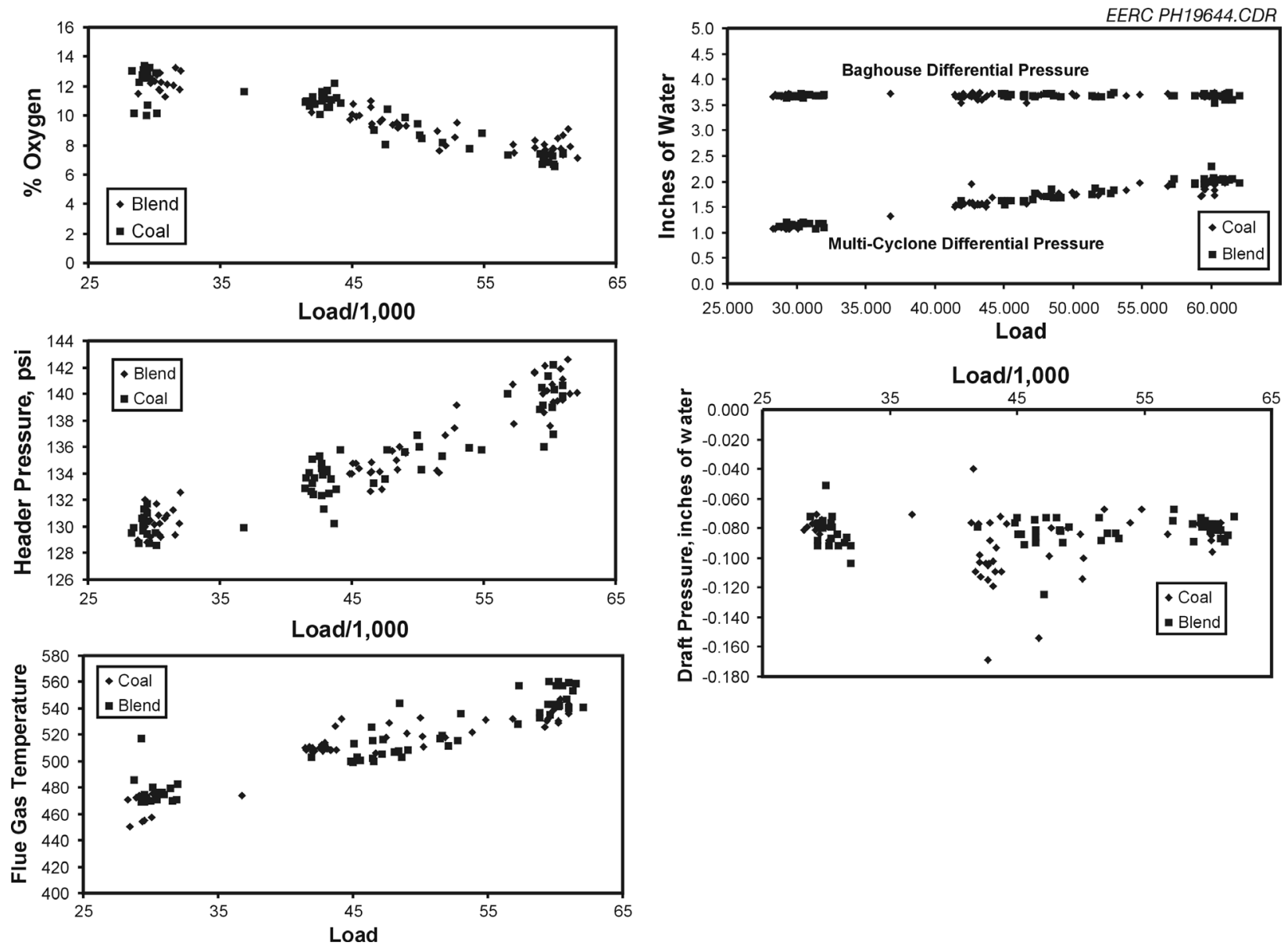

Figure 2-12. Performance data on Boiler 5 for baseline coal and sunflower-coal mixed feed.

- Equipment damage - none, thinner protective layer of ash on the grate. No backfires, no excessive pressures, no major hotspots, no stoker malfunction, and no increases in pressure drop in downstream systems were observed.

- Emissions $-\mathrm{SO}_{\mathrm{x}}$ and $\mathrm{NO}_{\mathrm{x}}$ were approximately $15 \%$ lower. Opacity ranged from $10 \%$ to $15 \%$.

- Performance - Existing stokers performed well in Boiler 5. Minimal segregation of the feed was observed in the storage bunker.

- Combustion - No major clinkers or differences in the ash were observed. 


\section{Summary Conclusions}

- Cofiring sunflower hulls will result in improved efficiency. Efficiency calculations show a 5\% increase at full load. Loss-on-ignition data support these calculations.

- Overall emissions and opacity are within acceptable limits and will generally improve with further optimization of the overfire air (test was approximately $5 \%$ overfire air, $40 \%$ is recommended).

- Investments in equipment will not be overbearing. No investments in overfire air nozzles, stokers, mixers, and separate conveyors were found to be necessary for Boilers 5 and 7.

- Future optimization tests would include the following:

- Overfire air adjustments

- Long-term assessment

- Grate speed adjustments

- Fines minimization

- Accurate temperature profiling

- Long-term inspection 


\section{Task 3 - Fuel-Handling Issues}

\section{Introduction}

The fuel-handling stages that are addressed in this task includes transportation, storage, and drying. Conveyance from the storage shed, mixing, and feeding were addressed in Task 2. The first task concluded that sunflower hulls were the optimal regional biomass resource for cofiring. This type of biomass will be used as our baseline biomass resource for determining cost and type of equipment. Although the equipment focus will be primarily on transporting and storing sunflower hulls, to as large an extent as possible, an objective of this task is to provide a universal transportation and storage fuel-handling system. The universal system should be flexible enough to handle many types of fuel. This would allow the UND steam plant facility to account for fluctuations in the biomass market and switch biomass suppliers and types if necessary.

\section{Transportation}

An evaluation was performed on the most economical method of transporting the sunflower hulls to the UND steam plant facility. The two types of transportation options studied were freight delivery and self-delivery. Both of these will be presented with an estimate of the cost per ton to haul sunflower hulls. Since sunflower hulls can be found in large quantities throughout the Grand Forks region, two locations were chosen for comparison, one relatively near to Grand Forks and the other relatively far. Dahlgren \& Company is located in Crookston, Minnesota, and is a strong candidate as a future supplier because of its location and the quantity of sunflower hulls it processes. The other location was Fargo, North Dakota. Both Red River Commodities, Inc., and Dakota Sunflower are located in or near Fargo, North Dakota. The final delivered price is affected by both the cost of the sunflower hulls and the transportation distance.

\section{Freight Delivery}

The baseline costs of transportation was determined by performing a phone survey of the local trucking companies on the long-term costs of transporting 9000 tons per year of sunflower hulls. This would equate to approximately a $20 \%$ by weight blend of sunflower hulls. Because of the low bulk density of the sunflower hulls, the cost of transportation is significantly higher than normal on a per ton basis. In general, approximately 15 tons of sunflower hulls can be transported per load. This is less than half of the maximum tonnage per load that can be hauled normally by truck. The estimates were $\$ 6.50-\$ 7.50$ per ton to transport sunflower hulls from Crookston to Grand Forks (approximately 25 miles) or $\$ 26-\$ 30$ per ton to transport sunflower hulls from sunflower processors in Fargo to Grand Forks (approximately 80 miles).

If the confection sunflower processor is in Crookston, Minnesota (within 30 miles of Grand Forks), then the transportation cost of hauling the sunflower hulls through an external trucking company is low enough to generate savings by cofiring sunflower hulls. Assuming a bulk price of $\$ 15$ per ton for the sunflower hulls, this would equate to a delivered cost of approximately $\$ 22$ per ton. Outside of 30 miles, the cost of transportation from an external trucking company increases dramatically and becomes prohibitive. In the case of transporting 
sunflower hulls from Fargo, North Dakota, the total delivered cost of sunflower hulls would vary between $\$ 41$ to $\$ 45$ per ton, making this option uneconomical.

\section{Self-Delivery}

An alternative to contract trucking is for the UND steam plant facility to perform the hauling itself. Table 3-1 gives a conservative estimate of the costs of a truck and driver to haul the sunflower hulls. The purchase price of the truck and trailer is based on a national survey of 96 used trucks (see Appendix A). The purchase price given in the table reflects the high-end cost of a truck and trailer no more than 2 years old with low miles. The actual purchase price of both the truck and the trailer may be significantly less. The estimate for the driver's salary is based on an hourly rate of $\$ 18.00$ per hour for 2400 hours per year full time or 1200 hours per year half time. Fringe benefits are not included in the calculation of driver's salary. The fuel cost is based on a fuel cost of $\$ 1.50$ per gallon, with an estimated fuel economy of 6 miles per gallon, making two trips per day to a confection sunflower processor. The first column shows the estimated cost of delivering 30 tons a day of sunflower hulls from Crookston, Minnesota. The second column shows the estimated cost of delivering 30 tons per day from Fargo, North Dakota.

Table 3-1. Cost of Purchasing a Truck and Full-Time Driver

\begin{tabular}{lcc}
\hline & $\begin{array}{c}\text { Half-Time Driver } \\
100 \text { miles/day }\end{array}$ & $\begin{array}{c}\text { Full-Time Driver } \\
320 \text { miles/day }\end{array}$ \\
\hline Truck Purchase Price & $\$ 50,000$ & $\$ 50,000$ \\
Trailer Purchase Price & $\$ 30,000$ & $\$ 30,000$ \\
Fuel Cost for 5 years (est. 6 miles/gal) & $\$ 38,250$ & $\$ 119,250$ \\
Misc. Maintenance for 5 years & $\$ 2,500$ & $\$ 5,000$ \\
Driver Salary & $\$ 108,000$ & $\$ 216,000$ \\
Total cost for 5 Years & $\$ 228,750$ & $\$ 420,250$ \\
Price per Ton Delivered & $\$ 5.08$ & $\$ 9.34$ \\
\hline
\end{tabular}

The cost per ton to deliver the sunflower hulls was averaged over 5 years to account for the typical payback period of the truck and trailer. The annual sunflower load was assumed to be 9000 tons, for a total of 45,000 tons over 5 years. After the initial 5-year payback period, the delivery cost per ton should decrease by approximately $35 \%$ for processors in Crookston and $20 \%$ for processors in Fargo.

The transportation costs are significantly lower if the UND steam plant performs the hauling. The transportation cost of delivering the sunflower hulls to the UND steam plant facility should run approximately $\$ 5.00-\$ 9.50$ per ton, depending on the distance of the confection sunflower processor from Grand Forks. Assuming a bulk price of $\$ 10$ per ton for the sunflower hulls, this would equate to a delivered cost of $\$ 15$ per ton for processors within 30 miles of Grand Forks (equating to a half-time driver) and $\$ 19.50$ per ton for processors within 80 miles of Grand Forks (equating to a full-time driver). 
In the final analysis, the delivery method is dependent primarily upon the distance of the confection sunflower processor from Grand Forks. Both freight delivery and self-delivery will generate savings if sunflower hulls are delivered within a 30-mile radius of Grand Forks. For distances greater than 30 miles, freight delivery is cost-prohibitive. In this case, self-delivery is the only economical option.

\section{Storage, Loading, and Discharging}

Prior to sizing, metering, and mixing the biomass with the coal, a storage system is required for the biomass. The storage bin must be located near the steam plant to facilitate efficient and economical conveyance of the biomass to the boilers, but it must also be situated in an area that will cause minimal disruption to the current workflow. The storage capacity was defined by the UND steam plant facility. It currently maintains a coal reserve large enough to run 7 days at full load. Its desire for storage volume was to provide 7 days' capacity at a $30 \%$ cofiring rate for full- load operation. Calculations based on the bulk density of sunflower hulls indicate a required storage volume of approximately 149,820 cubic feet $\left(4242 \mathrm{~m}^{3}\right)$. Although the biomass is expected to be delivered dry, some form of moisture control is needed in case of moisture condensation due to temperature and humidity fluctuations. A rapid loading system must be available to ensure efficient unloading of the biomass from the truck. Finally, a rapid unloading system is needed to ensure efficient conveyance of the biomass to the coal storage bunkers.

Fortunately, the agricultural industry has the experience and equipment to fulfill these specifications. Figure 3-1 gives a conceptual image of a typical high grain silo. This is the most economical layout for fulfilling the specifications. Because of space limitations around the steam

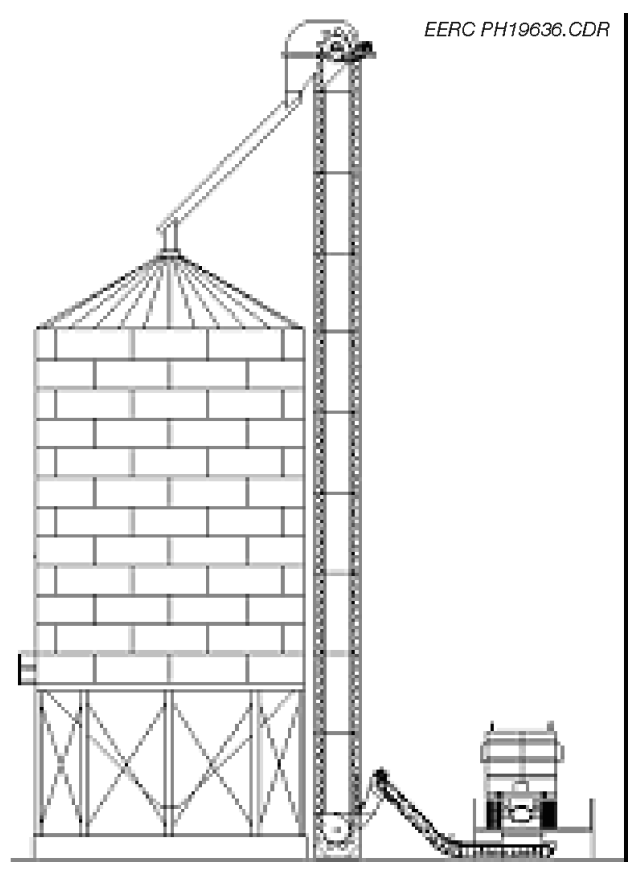

Figure 3-1. Typical grain silo. 
plant facility, a high grain silo is recommended to maximize volume per floor area. The silo diameter and height required to fulfill the capacity specifications is $48 \times 80 \mathrm{ft}$, respectively. The draft fan forces air through perforated ducts along the floor of the silo to create a uniform airflow through the silo and out the top. The proposed location for the silo is adjacent to the UND steam plant facility coal shed. In this location, discharge of the biomass can occur without interrupting the delivery and discharge of the coal. The delivery truck can unload the sunflower hulls directly into the small pit. A conveyor belt then transports the biomass to a bucket elevator that dumps it into the silo. Figure 3-2 is a photo of a similar layout. In this configuration the discharge time of the biomass is minimized. Unloading the biomass from the grain silo is accomplished by opening a valve at the bottom of the silo onto a screw feeder or a conveyor belt, which then transports the biomass to either the size reduction station or the storage bin.

\section{Size Reduction}

Although sunflower hulls can be delivered in a uniform size and shape that does not need additional sizing prior to mixing, the cost of an additional sizing station was investigated to allow for more flexibility in biomass choice. The size reduction station includes a dryer, screening table, and a hog. The addition of a size reduction station would give the steam plant the flexibility to cofire wood waste such as brush or tree waste when an economical opportunity presents itself.

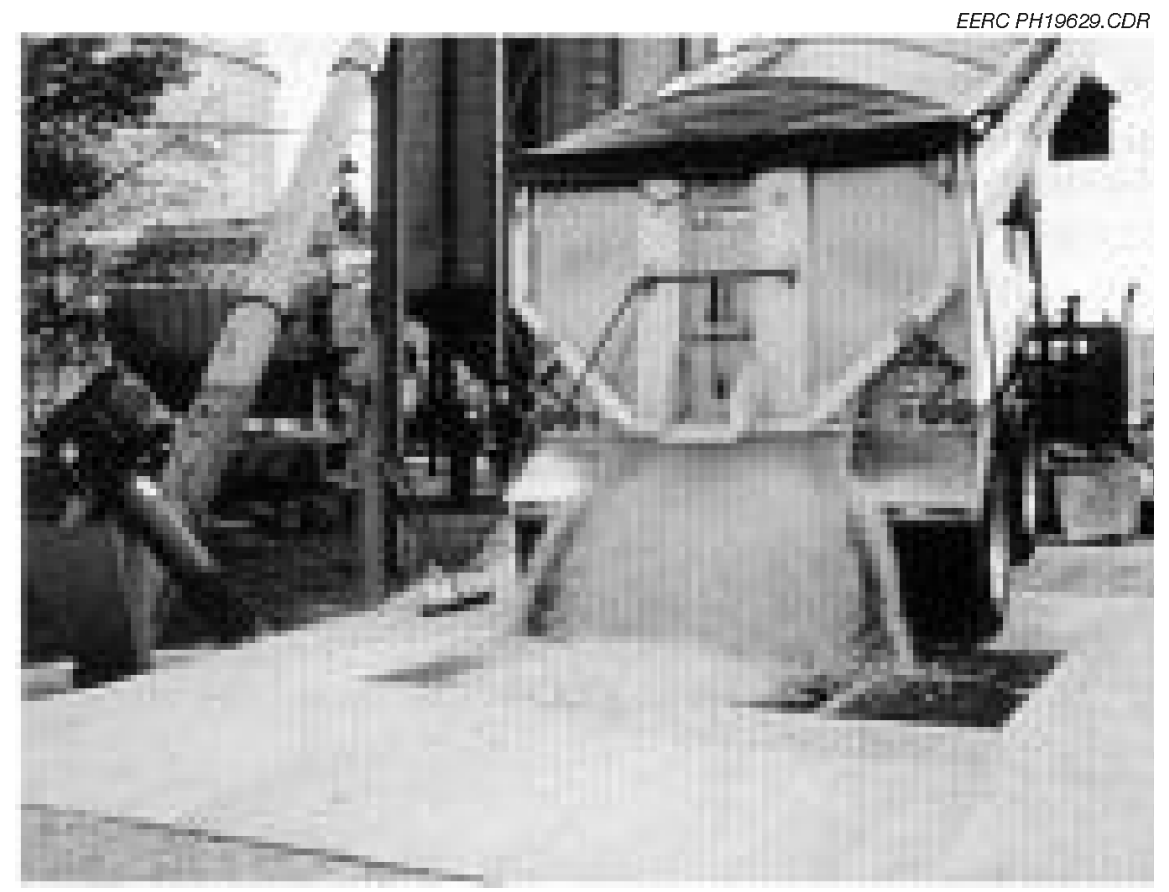

Figure 3-2. Unloading biomass for storage. 


\section{Metering}

Metering plays a very important role in cofiring biomass. Task 2 determined that in-line mixing with the feed system augers provided good mixing results and minimal coal attrition. The most economical metering method is to convey the biomass from the storage bin to the feed input system through a variable conveyor belt or auger system. By varying the rate that the biomass is fed to the feed system relative to the coal, the mix ratio can be maintained with minimal disruption to the workflow.

Three possible entry locations for the biomass are proposed. The biomass can be fed to the main coal pit or the auxiliary pit through belt conveyors or augers located under the coal shed. The flood fed coal could then be dumped directly on top of the biomass and transported to the bucket elevator. This would require the installation of a concrete trench system with a grate. The conveyance of the biomass to the coal pits would be transparent and cause minimal workflow disruption. Another option would be to convey the biomass directly to the feed system at the point that the bucket elevators unload the coal to the feed system. The biomass could be dumped on top of the coal just prior to its entering the feed system augers. This would require the installation of a bucket elevator and an overbunker screw conveyor system to transfer the biomass from the storage bin to the feed system input.

\section{Equipment Costs}

Figure 3-3 gives a conceptual design of the full biomass feed system along with the cost of several system variations. The capital costs include the cost of installing a concrete trench and the cost of the equipment. It does not include the cost of installing the equipment. Table 3.2a-f gives a more detailed breakdown of the costs.

Option 1 is an aerated silo, a dryer, a screening table, a hog, remodeling of the existing deep pit, replacing the overbunker belt conveyor with the screw conveyor, and using the existing bucket elevator and feeding system.

Option 1a is a simplified version of Option 1. It proposes the installation of an aerated silo and remodeling the existing deep pit, replacing the overbunker belt conveyor with the screw conveyor, and using the existing bucket elevator and feeding system.

Option 2 is an aerated silo, a dryer, a screening table, a hog, and using the existing deep pit, the existing bucket elevator, and feeding system.

Option $2 \mathrm{a}$ is a simplified version of Option 2. It proposes installing an aerated silo and using the existing small pit, the bucket elevator, and feeding system.

Option 3 uses a completely new elevating system. It proposes installing an aerated silo and building a new bucket elevator, using of an overbunker belt conveyor system, and using the existing bucket elevator for the coal feed.

Option 4 is to build a concrete wall in the cold shed and equip the storage with drag conveyors. A portable drag conveyor will transport sunflower hulls to the pit (mixing point). The 


\section{Options}

$\$ 328,711$ 1. Silo, dryer, screen, hog, modify deep pit, underground conveyor, new screw. $\$ 293,059$ 1a. Silo, underground conveyor, modify deep pit, new screw.

$\$ 280,711$ 2. Silo, dryer, screen, hog, underground conveyor, modify deep pit.

$\$ 245,059$ 2a. Silo, shallow pit.

$\$ 236,371$ 3. New bucket elevator + Option $1-$ no underground conveyor.

$\$ 345,1314$. Concrete in shed storage + Option 1.

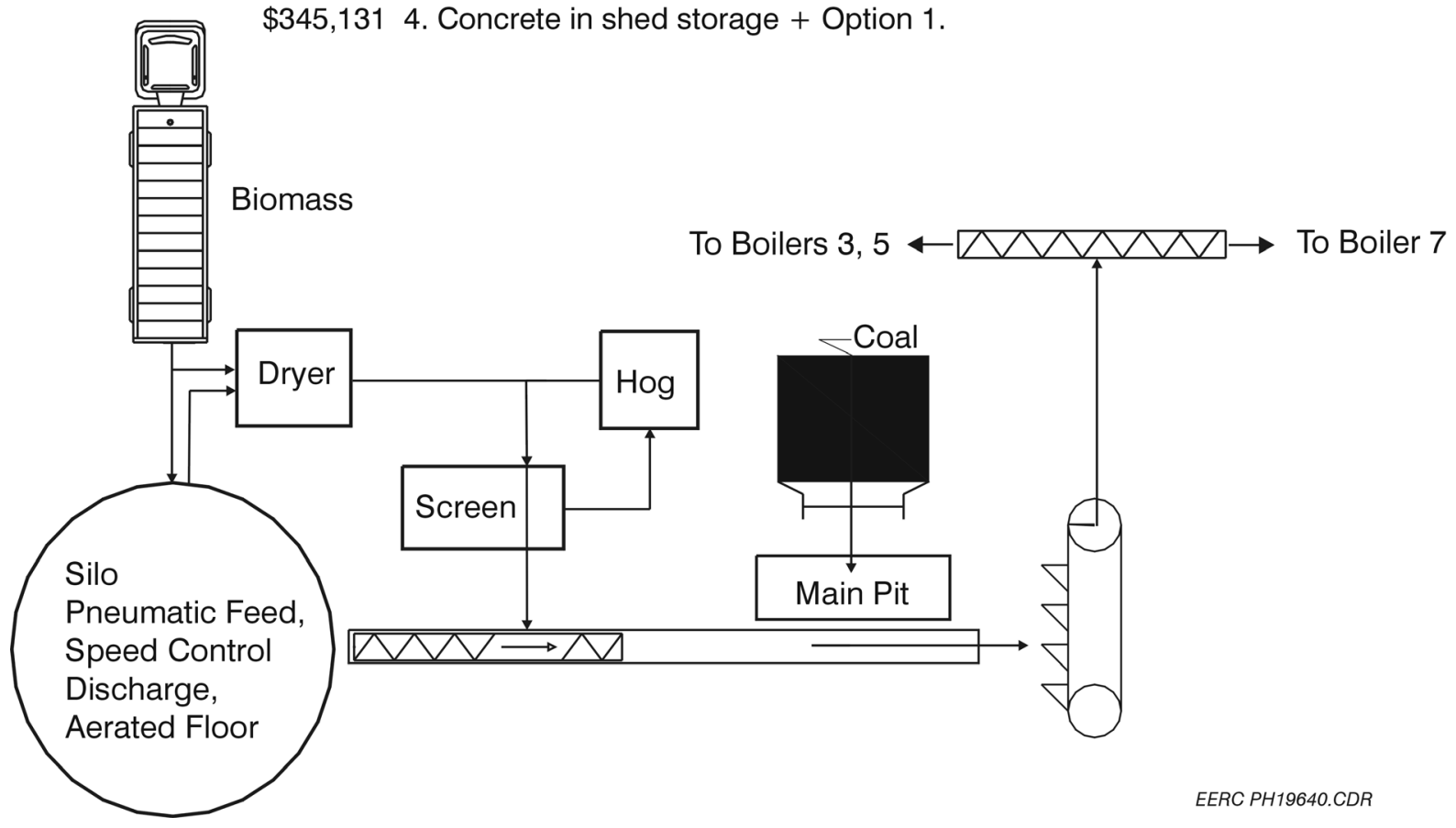

Figure 3-3. Conceptual design of biomass feed system.

deep pit should be remodeled, and the overbunker belt conveyor should be replaced with the screw conveyor.

Figures 3-4-6 give three possible design configurations for Options 2 through 4, respectively. These design configurations provide complete biomass handling systems. The actual design layouts relative to the existing facilities must be determined based on permitting issues and compatibility issues with the current facility structure. Additional design configurations for Options 1, 1a, and 2a are presented in the Appendix A. 


\section{Table 3-2a-f. Detailed Breakdown of Capital Costs}

\begin{tabular}{|c|c|c|c|}
\hline \multicolumn{3}{|l|}{ No. of the Option } & Cost, $\$$ \\
\hline \multicolumn{3}{|c|}{ Option 1: Small pit, pneumatic conveyor, multiple biomass capability } & 328,711 \\
\hline \multicolumn{3}{|c|}{ Option 1a: Small pit, pneumatic conveyor, sunflower hulls } & 293,059 \\
\hline \multicolumn{3}{|c|}{ Option 2: Main pit, pneumatic conveyor, multiple biomass capability } & 280,711 \\
\hline \multicolumn{3}{|c|}{ Option 2a: Main pit, pneumatic conveyor, multiple biomass capability } & 245,059 \\
\hline \multicolumn{3}{|c|}{ Option 3: Bucket elevator, multiple fuel system } & 236,371 \\
\hline \multicolumn{3}{|c|}{ Option 4: Concrete wall storage bin, main pit, conveyor } & 345,131 \\
\hline \multicolumn{4}{|l|}{ Table 3.2a - Option 1} \\
\hline Equipment & Quantity & Price per Unit, \$ & Total Price, $\$$ \\
\hline Hopper & 1 & 2,290 & 2,290 \\
\hline Auger & 6 & 325 & 1,950 \\
\hline Dryer & 1 & 26,027 & 26,027 \\
\hline Screening Table & 1 & 3,000 & 3,000 \\
\hline Hog & 1 & 5,000 & 5,000 \\
\hline Overbunker Screw Conveyor & 1 & 3,000 & 3,000 \\
\hline Storage & 1 & 176,790 & 176,790 \\
\hline Pneumatic Conveyor & 1 & 52,340 & 52,340 \\
\hline Aeration Fan & 1 & 1,314 & 1,314 \\
\hline Deep Pit Remodeling & & & 30,000 \\
\hline Underground Screw Conveyor & 1 & 15,000 & 15,000 \\
\hline Main Pit Screw Conveyors & 4 & 3,000 & 12,000 \\
\hline Total & & & 328,711 \\
\hline
\end{tabular}

Table 3.2b - Option 1a

\begin{tabular}{lccc}
\hline Equipment & Quantity & Price per Unit, \$ & Total Price, \$ \\
\hline Hopper & 1 & 2,290 & 2,290 \\
Auger & 1 & 325 & 325 \\
Overbunker Screw Conveyor & 1 & 3,000 & 3,000 \\
Pneumatic Conveyor & 1 & 52,340 & 52,340 \\
Storage & 1 & 176,790 & 176,790 \\
Aeration Fan & 1 & 1,314 & 1,314 \\
Deep Pit Remodeling & & & 30,000 \\
Underground Screw Conveyor & 1 & 15,000 & 15,000 \\
Main Pit Screw Conveyors & 4 & 3,000 & 12,000 \\
Total & & & 293,059
\end{tabular}

Table 3.2c - Option 2

\begin{tabular}{lccc}
\hline Equipment & Quantity & Price per a Unit, \$ & Total Price, \$ \\
\hline Hopper & 1 & 2,290 & 2,290 \\
Auger & 6 & 325 & 1,950 \\
Dryer & 1 & 26,027 & 26,027 \\
Screening Table & 1 & 3,000 & 3,000 \\
Hog & 1 & 5,000 & 5,000 \\
Storage & 1 & 176,790 & 176,790 \\
\hline
\end{tabular}

Continued ... 
Table 3-2a-f (continued)

\begin{tabular}{|c|c|c|c|}
\hline Pneumatic Conveyor & 1 & 52,340 & 52,340 \\
\hline Aeration Fan & 1 & 1,314 & 1,314 \\
\hline Underground Screw Conveyor & 1 & 12,000 & 12,000 \\
\hline Total & & & 280,711 \\
\hline \multicolumn{4}{|l|}{ Table 3-2d - Option 2a } \\
\hline Equipment & Quantity & Price per Unit, \$ & Total Price, $\$$ \\
\hline Hopper & 1 & 2,290 & 2,290 \\
\hline Auger & 1 & 325 & 325 \\
\hline Storage & 1 & 176,790 & 176,790 \\
\hline Pneumatic Conveyor & 1 & 52,340 & 52,340 \\
\hline Aeration Fan & 1 & 1,314 & 1,314 \\
\hline Underground Screw Conveyor & 1 & 12,000 & 12,000 \\
\hline Total & & & 245,059 \\
\hline \multicolumn{4}{|l|}{ Table 3-2e - Option 3} \\
\hline Equipment & Quantity & Price per Unit, $\$$ & Total Price, $\$$ \\
\hline Hopper & 1 & 2,290 & 2,290 \\
\hline Auger & 6 & 325 & 1,950 \\
\hline Dryer & 1 & 26,027 & 26,027 \\
\hline Screening Table & 1 & 3,000 & 3,000 \\
\hline Hog & 1 & 5,000 & 5,000 \\
\hline Bucket Elevator & 1 & 12,000 & 12,000 \\
\hline Belt Conveyor & 1 & 5,000 & 5,000 \\
\hline Storage & 1 & 176,790 & 176,790 \\
\hline Aeration Fan & 1 & 1,314 & 1,314 \\
\hline Overbunker Screw Conveyor & 1 & 3,000 & 3,000 \\
\hline Total & & & 236,371 \\
\hline \multicolumn{4}{|l|}{ Table 3-2f - Option 4} \\
\hline Equipment & Quantity & Price per Unit, \$ & Total Price, $\$$ \\
\hline Hopper & 1 & 2,290 & 2,290 \\
\hline Auger & 1 & 325 & 325 \\
\hline Dryer & 1 & 26,027 & 26,027 \\
\hline Screening Table & 1 & 3,000 & 3,000 \\
\hline Hog & 1 & 5,000 & 5,000 \\
\hline Drag Conveyor & 2 & & \\
\hline Portable Drag Conveyor & 1 & 4,175 & 4,175 \\
\hline Screw Conveyor & 1 & 3,000 & 3,000 \\
\hline Concrete Storage & 1 & 300,000 & 300,000 \\
\hline Aeration Fan & 1 & 1,314 & 1,314 \\
\hline Overbunker Screw Conveyor & 1 & 3,000 & 3,000 \\
\hline Total & & & 345,131 \\
\hline
\end{tabular}




\section{Option 2}

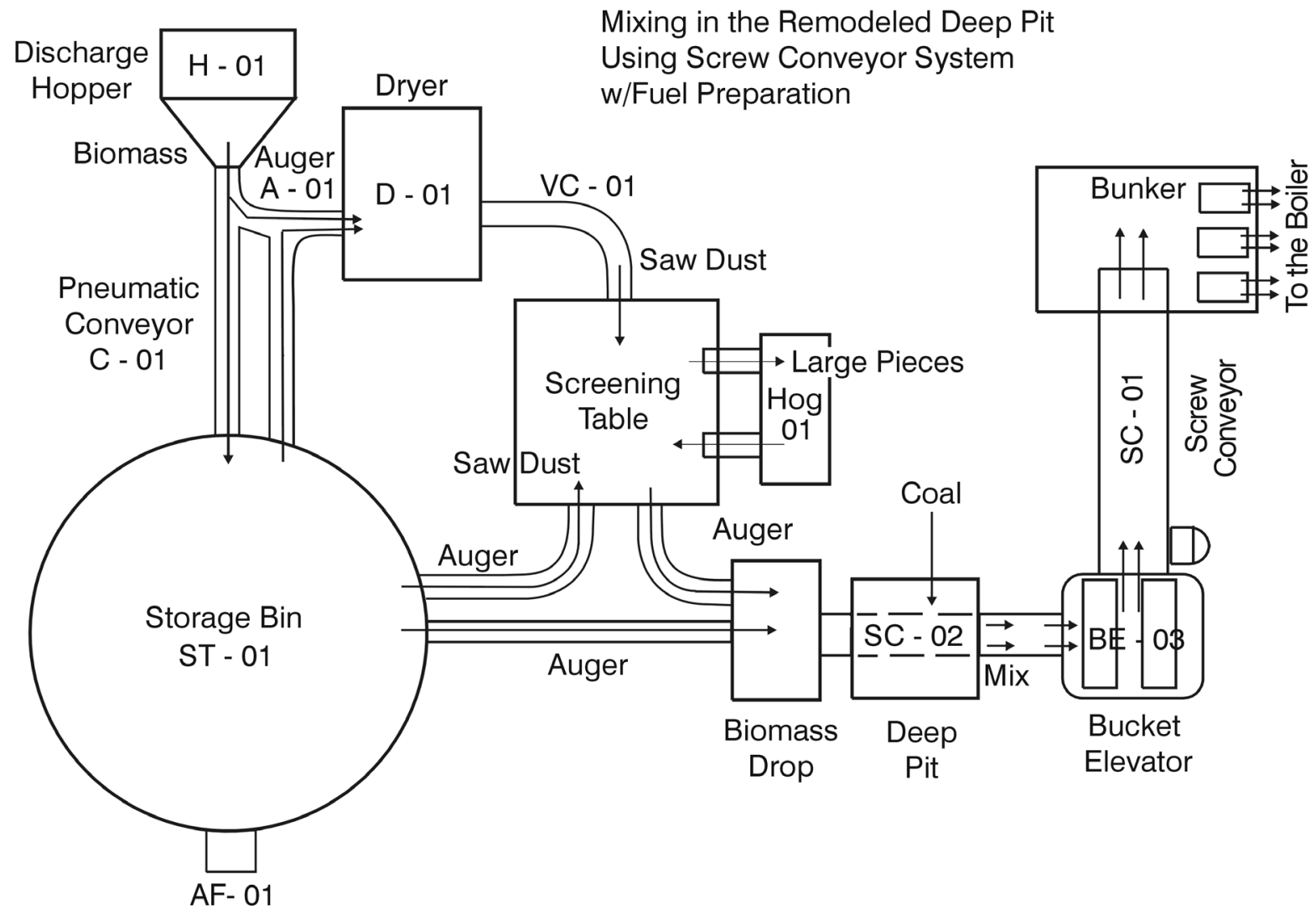

Figure 3-4. Proposed layout configuration for Option 2. 


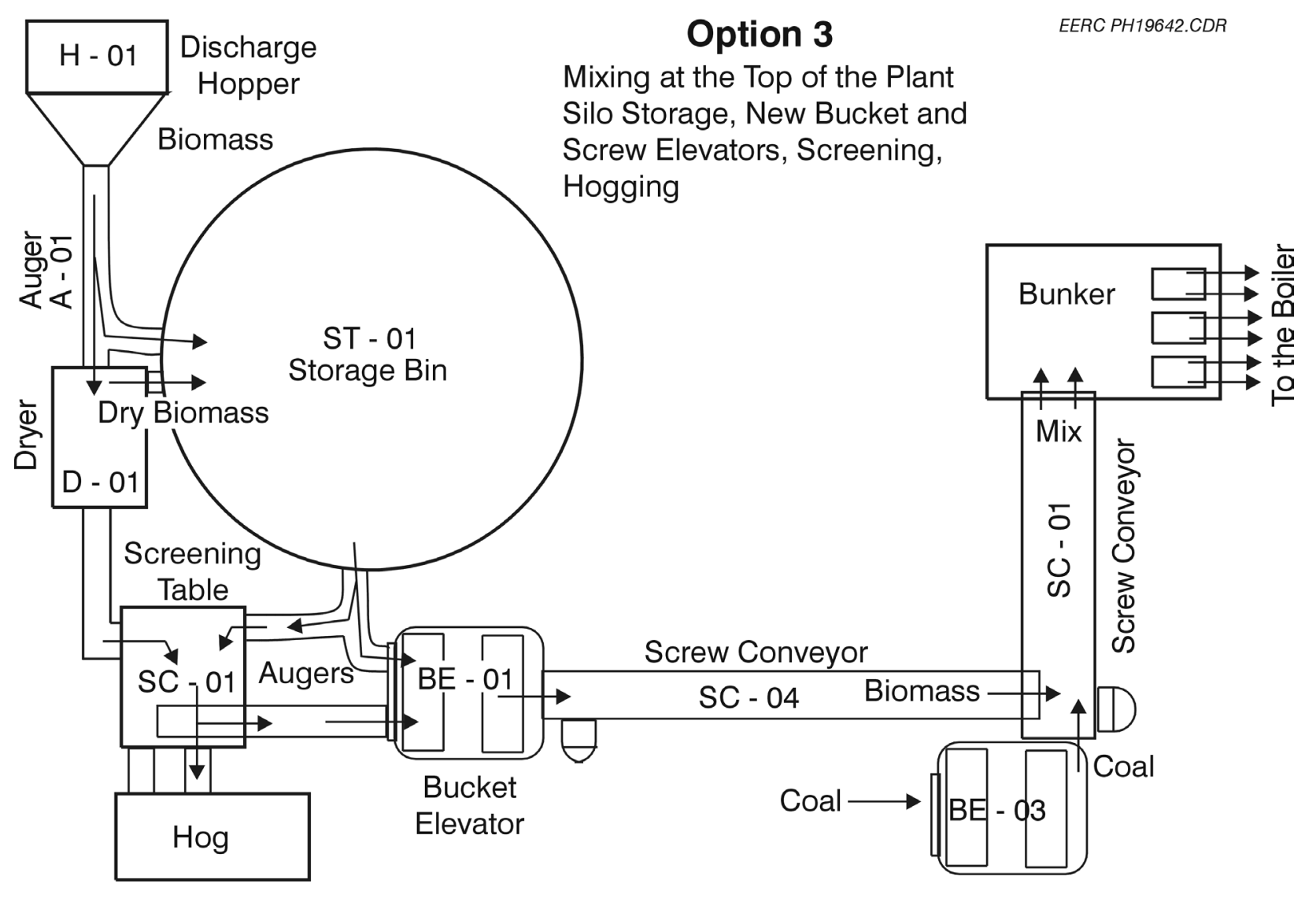

Figure 3-5. Proposed layout configuration for Option 3. 


\section{Option 4}

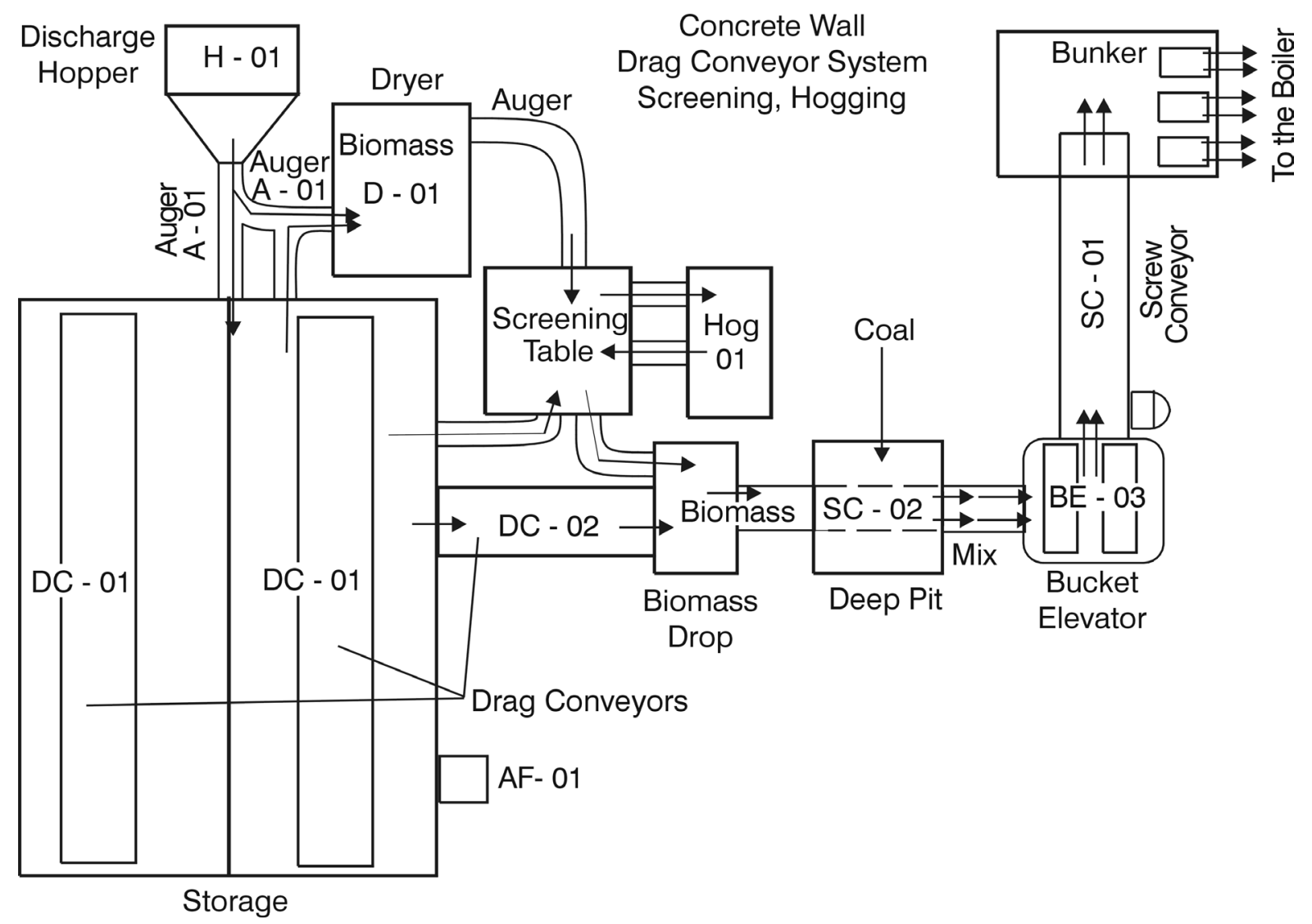

Figure 3-6. Proposed layout configuration for Option 4. 


\section{Task 4 - Engineering Economic Analyses}

\section{Introduction}

The engineering economic analysis calculates the payback for the initial capital costs required to convert the UND steam plant facility to a cofiring facility.

\section{Economics}

Figure 4-1 gives a cash flow analysis for cofiring sunflower hulls $25 \%$ by weight with coal for 10 years. The cash flow analysis assumes that the savings produced in the early years of the project would be used for early payoff of the 10-year financiing. Figure 4.2 shows the schedule of payments to pay off the bond in 5 years. The amount financed is assumed to be Option 1 with the purchase of a truck for self-delivery. The calculations assume a bond loan at the interest rate of $5.25 \%$ for 10 years. Escalation rates for the coal and electricity are based on the annual stateallotted increases for these utilities. The O\&M escalation rate is based on the rate of inflation. No national data exist to our knowledge on the cost history of sunflower hulls. Since sunflower hulls are a waste by-product, whose primary market is livestock bedding, the cost is assumed to be dictated by the lowest-cost alternative for livestock bedding. As such, we assumed the cost of sunflower hulls to be very stable and assigned an escalation rate of $0 \%$.

The cost additions as outlined in Figure 4-1 include two additional employees for labor, a long-term contract for sunflower hulls at $\$ 10 /$ ton, the self-delivery option, and a relatively high electricity usage rate and maintenance cost. Over 10 years, the cost savings after making advanced payments on the bond is $\$ 596,022$.

Figure 4.3 shows a sensitivity analysis for various economic parameters. The last column assigns a weighting factor indicating which parameter has the greatest effect. Coal price, percentage of sunflower hulls fired, and sunflower hull price have the greatest impact on project economics. In order to keep the economics below a 10-year payback, the sensitivity analysis indicates that coal cannot be cheaper than $\$ 26.00 /$ ton, sunflower hulls cannot be greater than $\$ 14.00 /$ ton delivered, and at least $15 \%$ by weight must be cofired. Operations and maintenance have very little effect on the economics.

\section{Conclusion}

The economics for cofiring sunflower hulls at UND are quite attractive. This cofiring scenario assumes a cofiring rate of $25 \%$ sunflower hulls by weight. This requires about 12,000 tons/year of biomass, which is only $25 \%$ of the amount produced by the closest processor. The required capital investment is $\$ 408,711$ to install a storage silo and purchase a used tractor-trailer for transportation and fuel-conveying equipment. The savings generated can pay back a 10 -year bond financed at $5.25 \%$ in 5 years with advanced payments from the savings. The energy cost savings accounting for additional O\&M is about $\$ 100,000$ per year. Actual savings after debt service is approximately $\$ 50,000$ per year. 


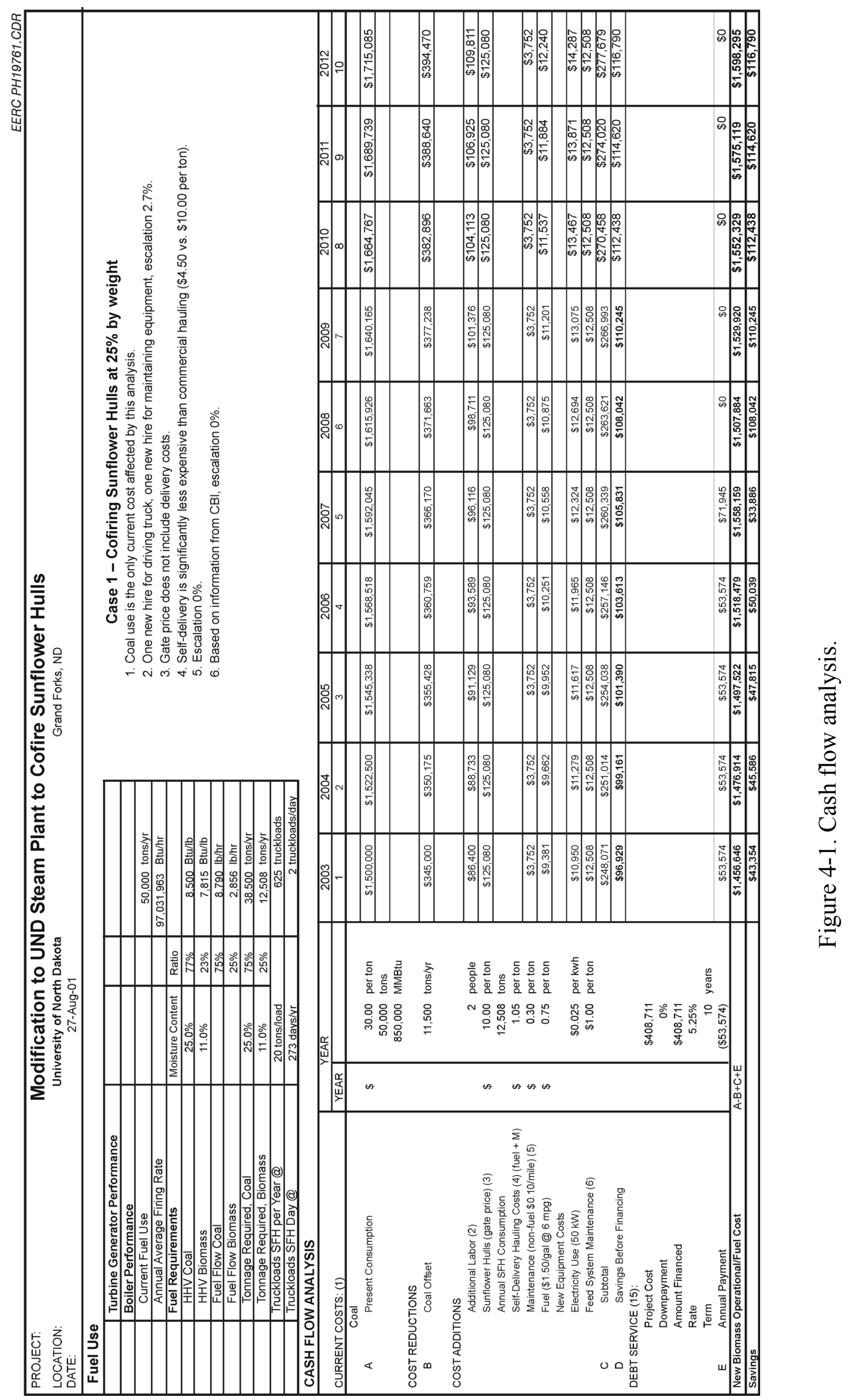




\begin{tabular}{|c|c|c|c|c|c|c|c|c|c|c|}
\hline \multirow{3}{*}{$\begin{array}{l}\begin{array}{l}\text { Financing Calculations } \\
\text { Payment schedule) }\end{array} \\
\text { Financed Amount } \\
\text { Rate } \\
\text { Term }\end{array}$} & \multicolumn{2}{|c|}{ (regular } & \multicolumn{8}{|c|}{ Payment Schedule Using Advanced Payments from Energy Savings } \\
\hline & \multirow{2}{*}{\multicolumn{2}{|c|}{$\begin{array}{c}\$ 408,711 \\
5.25 \% \\
10\end{array}$}} & Key Figures & \multicolumn{3}{|c|}{ Inputs } & \multicolumn{3}{|c|}{ Calculated Numbers } & \\
\hline & & & Annual Loan Payment & \multicolumn{3}{|c|}{$\$ 53,574$ Loan Principal Amount } & \multicolumn{3}{|c|}{$\$ 408,711$ Effective Annual Interest } & 5.25 \\
\hline $\begin{array}{l}\text { Payment } \\
\text { Principal }\end{array}$ & & $\begin{array}{l}(\$ 53,574) \\
\$ 408,711\end{array}$ & $\begin{array}{l}\text { Payment per Year } \\
\text { Payment Amount }\end{array}$ & \multirow{2}{*}{$\begin{array}{l}\$ 53,574 \\
\$ 53,574\end{array}$} & \multicolumn{2}{|c|}{ Annual Interest Rate, \% } & \multicolumn{3}{|c|}{ 5.25 Effective Period Interest } & $\begin{array}{r}5.25 \\
1.668096016\end{array}$ \\
\hline Interest & $\underline{s}$ & 127,034 & Interest in First Year & & \# of Pay Periods/ & & \multicolumn{3}{|c|}{1 A/P Factor } & 0.131081519 \\
\hline \multirow[t]{8}{*}{ Total } & $s$ & 535,745 & \multirow{2}{*}{$\begin{array}{l}\text { Total Interest } \\
\text { Total Payments } \\
\text { Total Amount Payed }(I+P+F)\end{array}$} & \multirow{2}{*}{\multicolumn{3}{|c|}{$\begin{array}{l}\text { Compounding Freq. } \\
10 \text { Starting Year of Loan } \\
\text { Starting Month of Loan }\end{array}$}} & \multirow[t]{2}{*}{1} & & & \\
\hline & & & & & & & & & & 53574.45886 \\
\hline & & & $\begin{array}{ll}\text { Payment } \\
\text { Number }\end{array}$ & $\begin{array}{l}\text { Begin } \\
\text { Balance }\end{array}$ & Payments & Principal & Interest & $\begin{array}{c}\text { Cumulative } \\
\text { Principal }\end{array}$ & $\begin{array}{l}\text { Cumulative } \\
\text { Interest }\end{array}$ & $\begin{array}{l}\text { Ending } \\
\text { Balance }\end{array}$ \\
\hline & & & 1 & $\$ 408,711$ & $\$ 96,929$ & $\$ 75,471$ & $\$ 21,457$ & $\$ 75,471$ & $\$ 21,457$ & $\$ 333,240$ \\
\hline & & & 2 & $\$ 333,240$ & $\$ 99,161$ & $\$ 81,666$ & $\$ 17,495$ & $\$ 157,137$ & $\$ 38,952$ & $\$ 251,574$ \\
\hline & & & 3 & $\$ 251,574$ & $\$ 101,390$ & $\$ 88,182$ & $\$ 13,208$ & $\$ 245,319$ & $\$ 52,160$ & $\$ 163,392$ \\
\hline & & & 4 & $\$ 163,392$ & $\$ 103,613$ & $\$ 95,035$ & $\$ 8,578$ & $\$ 340,354$ & $\$ 60,738$ & $\$ 68,357$ \\
\hline & & & 5 & $\$ 68,357$ & $\$ 71,945$ & $\$ 68,356$ & $\$ 3,589$ & $\$ 408,711$ & $\$ 64,327$ & so \\
\hline
\end{tabular}

Figure 4-2. Financing and payoffs.

\begin{tabular}{|c|c|c|c|c|c|c|c|c|}
\hline \multicolumn{4}{|c|}{ Sensitivity Analysis } & \multicolumn{2}{|c|}{ Annualized Savings } & \multicolumn{2}{|c|}{$\begin{array}{l}\text { Advanced Payback } \\
\text { on Debt, years }\end{array}$} & \multirow[b]{2}{*}{ Sensitivity } \\
\hline & & & & Base & $\$ 52,458$ & Base & 5 & \\
\hline Variable & Base & High & Low & High & Low & High & Low & Net Effect \\
\hline Sunflower Hull Price, \$/ton & $\$ 10$ & $\$ 14$ & $\$ 5$ & $\$ 2,400$ & $\$ 115,000$ & 9 & $\overline{3}$ & 2.39 \\
\hline SFH Mix \% & $25 \%$ & $35 \%$ & $15 \%$ & $\$ 148,000$ & $\$ 5,000$ & 2 & 9 & 4.55 \\
\hline SFH Tonnage & 12,508 & 17,946 & 9,789 & & & & & \\
\hline Feed System O\&M, \$/ton & $\$ 1.00$ & $\$ 3.00$ & $\$ 0.50$ & $\$ 23,616$ & $\$ 59,669$ & 6 & 4 & 0.27 \\
\hline Capital Investment & $\$ 408,711$ & $\$ 600,000$ & $\$ 250,000$ & $\$ 27,384$ & $\$ 73,262$ & 7 & 3 & 1.02 \\
\hline Coal Price, $\$$ /ton & $\$ 30$ & $\$ 35$ & $\$ 26$ & $\$ 100,854$ & $\$ 2,700$ & 3 & 9 & 5.54 \\
\hline
\end{tabular}

Figure 4-3. Projected payment schedule. 


\section{Task 5 - Energy Production Assessment}

\section{Introduction}

For this task, the electricity rates for UND were considered to determine if an electricity cogeneration option is economically feasible. We also investigated permitting issues to determine if there were any permitting issues that might obstruct the conversion of the UND steam plant facility to a cofiring facility.

\section{Electricity Cogeneration Assessment}

The cogeneration of electricity was considered and was determined not feasible. UND obtains a considerable Western Area Power Association (WAPA) allotment, which enables the purchase of low-cost hydroelectricity. When demand, use, and fees are averaged, the combined cost of electricity for UND is $\$ 0.024 / \mathrm{kWh}$.(Schmidt et al., 1999). UND produces $670 \mathrm{MMlb}$ of steam per year from 50,000 tons of coal. Assuming a $25 \%$ mix ratio and a nominal cost of $\$ 30 /$ ton for coal and $\$ 15 /$ ton for sunflower hulls, the total annual fuel cost would be $\$ 1,312,500$. If all of the steam were used to generate electricity at the typical $20 \%$ isentropic efficiency for a small-scale steam turbine, the total cost of electricity is calculated to be at least $\$ 0.033$. This calculation only considers the cost of the fuel. Since this cost exceeds the electricity rate of the University, no efforts to determine the benefit of electrical generation via steam turbines were investigated.

\section{Changes in Boiler Emissions and Their Effect on Permitting}

\section{Air Emissions}

Switching fuel from coal to biomass or a blend of coal and biomass typically has a beneficial impact with regard to stack emissions. Most biomass sources are low in sulfur and result in substantially lower $\mathrm{SO}_{2}$ emissions for the same fuel input. Biomass typically has lower ash content, resulting in lower amounts of uncontrolled particulate emissions; however, the particulates generated from burning biomass are typically finer than coal ash and may or may not lead to lower stack emissions. When burned wet, biomass will also reduce flame temperatures during combustion and can produce lower levels of $\mathrm{NO}_{\mathrm{x}}$.

UND operates its current boilers under a North Dakota Department of Health (NDDH) Air Pollution Control Permit. The permit sets the stack emission limits for the B\&W (Boiler 5) spreader stoker at $0.8 \mathrm{lb} / \mathrm{MMBtu}$ for particulate matter and opacity of $40 \%$. The coal-fired boiler currently meets the stack particulate emissions and opacity requirements. As discussed previously, a trial burn at nonoptimized conditions resulted in an increase of opacity from a baseline of $10 \%$ while firing coal to $15 \%$ when the blend of sunflower hulls and coal is fired. Changes in boiler operation are recommended to accommodate firing the blend of coal and sunflower hulls, primarily overfire air control, which is expected to reduce the amount of particulate matter that leaves the boiler. Therefore, it is anticipated that although particulate emissions and opacity may increase slightly, they will still be within the permit limits of the boiler. Changes in control of overfire air should also reduce the amount of unburned carbon in the ash, which may further decrease particulate emissions.

Current coal selection is based on sulfur content, with a maximum coal sulfur content of 
$1.3 \%$ on an as-received basis, as specified in UND's permit to operate. This restriction was implemented to ensure acceptable ambient air quality on the UND campus. The current sulfur content of the subbituminous coal fired at the steam plant is $0.6 \%$. For sunflower hulls, it is $0.3 \%$. Blending the lower-sulfur-content $(27 \%)$ sunflower hulls with the current coal should result in a decrease in $\mathrm{SO}_{2}$ emissions by $10 \%-15 \%$.

Emissions of $\mathrm{NO}_{\mathrm{x}}$ are not expected to change substantially from the current conditions with the firing of the sunflower hull:coal blend. If operational changes are made to the control of overfire air, a slight reduction in $\mathrm{NO}_{\mathrm{x}}$ may be noted.

The recommendations of this study are focused on switching from coal to a coal:biomass blend. The total hours of operation and the production rate of the boilers are not expected to change and will remain a function of the campuswide steam demands. Therefore, the total annual emissions of all priority pollutants are not expected to change significantly and should not impact UND's Title V permit.

Because the switch from coal to a coal:biomass blend will not significantly impact emissions of any of the regulated pollutants, air permit actions are minimal. UND will be required to inform NDDH in writing of the proposed change in fuel mix, including the expected emissions under the new operating scenario. Upon review of this letter, NDDH will issue a response granting authorization to proceed with the planned modifications. NDDH will require stack testing to verify the estimated emission levels once boiler modifications are complete. A final permit modification adding a clause allowing UND to burn a blend of coal and sunflower hulls will be granted based upon favorable results of these stack tests. All existing conditions of the air control permit are expected to remain in effect.

\section{Solid Waste Considerations}

UND is not required to have a solid waste permit under its current mode of operation. Small facilities are typically allowed to dispose of their ash and other residues directly to the landfill. Under the current mode of operation, approximately 13,500 tons/year of ash is generated that must be disposed of at the landfill. Using a 78:22 coal:sunflower hull blend, this would decrease slightly to approximately 12,600 tons/year, would still be benign, and would not requiring a solid waste permit.

\section{Water Quality/Storm Water Runoff}

Generally speaking, if processed fuel and/or ash is stored exposed to the elements, the type of material to be stored needs to be identified, along with the potential material in the runoff. This information is used by the Water Quality Office of NDDH to determine if a storm runoff permit is required and to set permit discharge levels. UND would need to submit a statement of its storage plans for the sunflower hulls to indicate how this storage option impacts its current storm runoff plan.

\section{Transfer Station Permitting}


Under some scenarios, a site receiving a waste material must obtain a transfer station permit. Recyclable/reuse material is typically granted an exemption, since this material, if recycled or reused, is not a waste. In the case of the proposed project with UND, an exemption from transfer station permitting is expected since the sunflower hulls will be considered a fuel, rather than a waste. Additionally, many states encourage this type of operation since it significantly reduces the burden on the landfill.

\section{Conclusion}

There is a tremendous opportunity to increase the use of biomass through cofiring. Facilities that have already invested in fossil fuel energy infrastructure can cofire biomass with limited investments in process modifications. The projects described in this paper provide case studies that can be utilized by others to determine how to approach potential projects. It is paramount to realize that the economics for using biomass can be marginal in many applications. The investigator must take considerable measures to ensure attractive return on investments. The key components include the following:

- A comprehensive biomass resource assessment focusing on quantity, cost, quality, reliability, and availability of the local resources.

- Fuel transportation, handling, and feeding design focused on minimizing capital investment, integrating with existing infrastructure, and proper design for difficult biomass fuels.

- Actual firing tests to ensure proper boiler modifications.

- Economic analysis.

With the proper integration of these issues, the benefits of reduced emissions, landfill diversion, and potential economic development can be realized.

The feasibility studies have provided the following salient project points:

- A combination of agricultural processing residues and wood from primary processors proved feasible as potential cofiring fuels.

- Biomass (sunflower hulls) could be delivered for $\$ 15 /$ ton at half the price of coal. Investing in self-transportation of the fuel can provide for better economics at half the cost of commercial transportation.

- Sunflower hulls handle well in existing coal feed equipment.

- Bin segregation of the mixed fuel is minimal under the proper conditions.

- Overthrow stokers can handle a $25 \%$ mix of biomass with coal.

- Augers provide for good mixing action of biomass and coal. 
- Sulfur and $\mathrm{NO}_{\mathrm{x}}$ emissions decreased by $15 \%$ with a $25 \%$ cofiring rate. Opacity can increase, but should be controlled by increasing overfire air rates. Location of overfire air nozzles can be critical.

- Grate speeds should be slowed since lower amounts of ash will be available to cover and protect the grate.

- UND firing 50,000 tons/year of coal at \$30/ton can realize payback of less than 5 years by cofiring biomass at $25 \%$. 


\section{REFERENCES}

DOE. www.doe.eia.gov, accessed March 30, 2000.

Glassner, D.A.; Hettenhaus, J.R.; Schechinger, T.M. Corn Stover Collection Project. In Proceedings of the Bioenergy 98' Conference.

Mory, A.; Tauschitz, J. Co-Combustion of Biomass in Coal-Fired Power Plants in Austria. VGB PowerTech 1999, 50-55.

Schmidt, D.D.; Pavlish, J.H.; Richter, J.J. Rebuild America with the University of North Dakota; Report for North Dakota Office of Intergovernmental Assistance and the University of North Dakota Physical Plant; Energy \& Environmental Research Center: Grand Forks, ND, June 1999.

Schmidt, D.D.; Pinapati, V. Opportunities for Small Biomass Power Systems; Final Technical Report for U.S. Department of Energy Contract No. DE-FG02-99EE35128; EERC Publication 2000-EERC-11-01; Energy \& Environmental Research Center: Grand Forks, ND, Nov 2000.

USDA. www.nass.usda.gov/nd/janrank.htm, accessed 2001.

Vogel, K.P.; Masters, R.A. Developing Switchgrass into a Biomass Fuel Crop for the Midwestern USA. In Proceedings of the Bioenergy 98' Conference; Madison, WI, Oct 4-8, 1998. 
APPENDIX A RESOURCE ASSESSMENT 


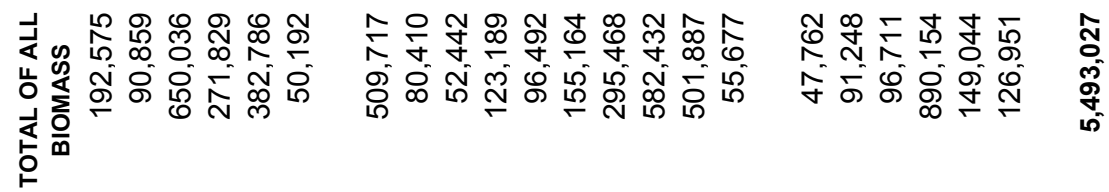

家

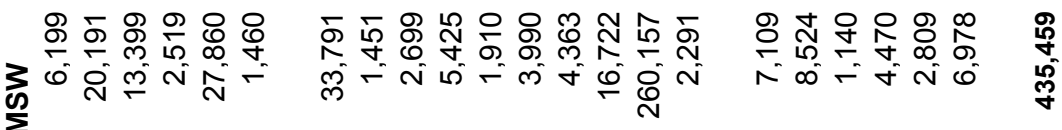

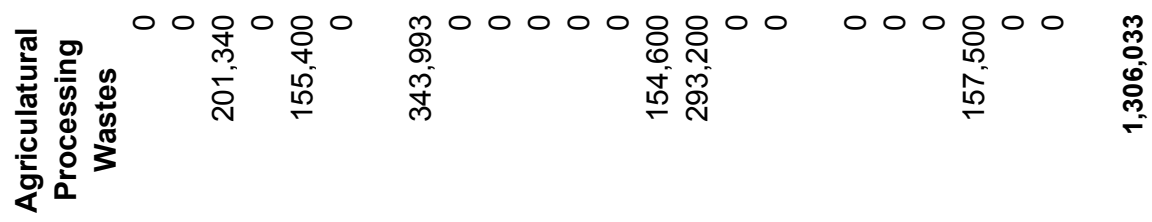

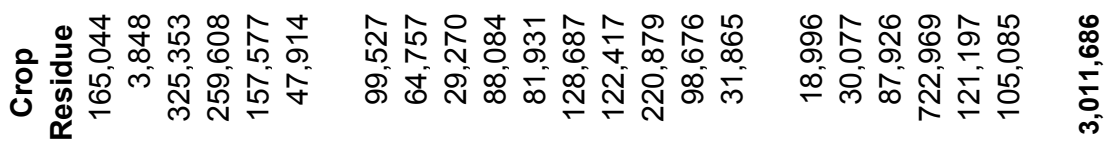

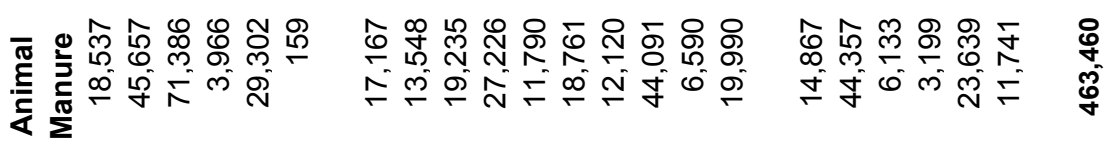

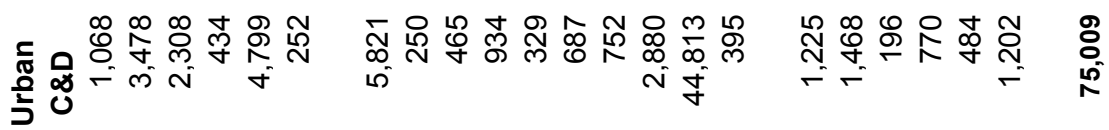

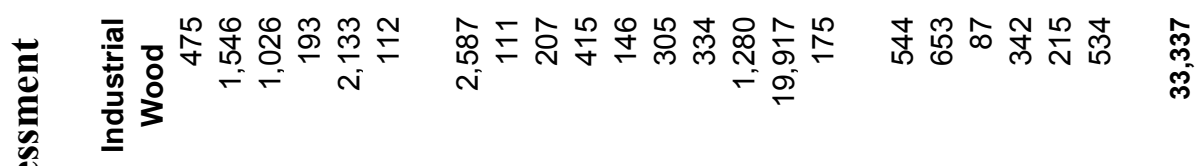

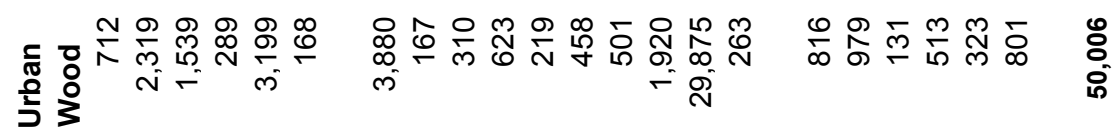

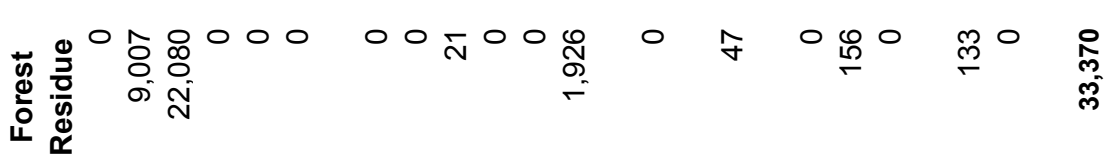

包 =

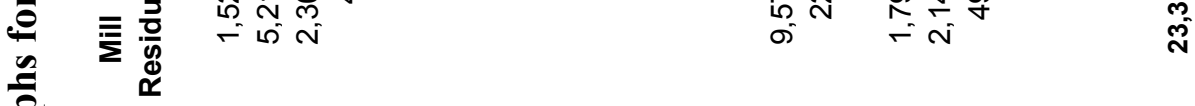

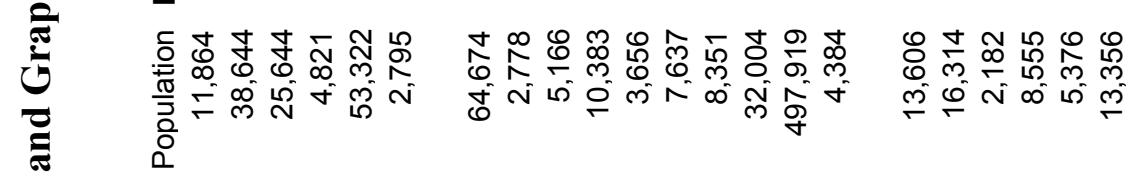

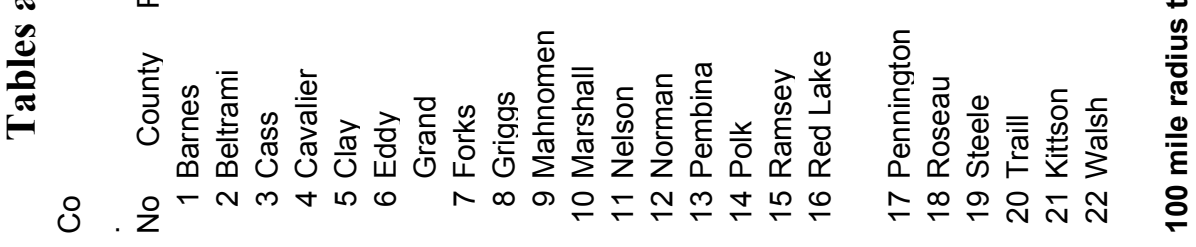


Alternative Layout proposals

Proposed Layout Configuration for Equipment Option \#4

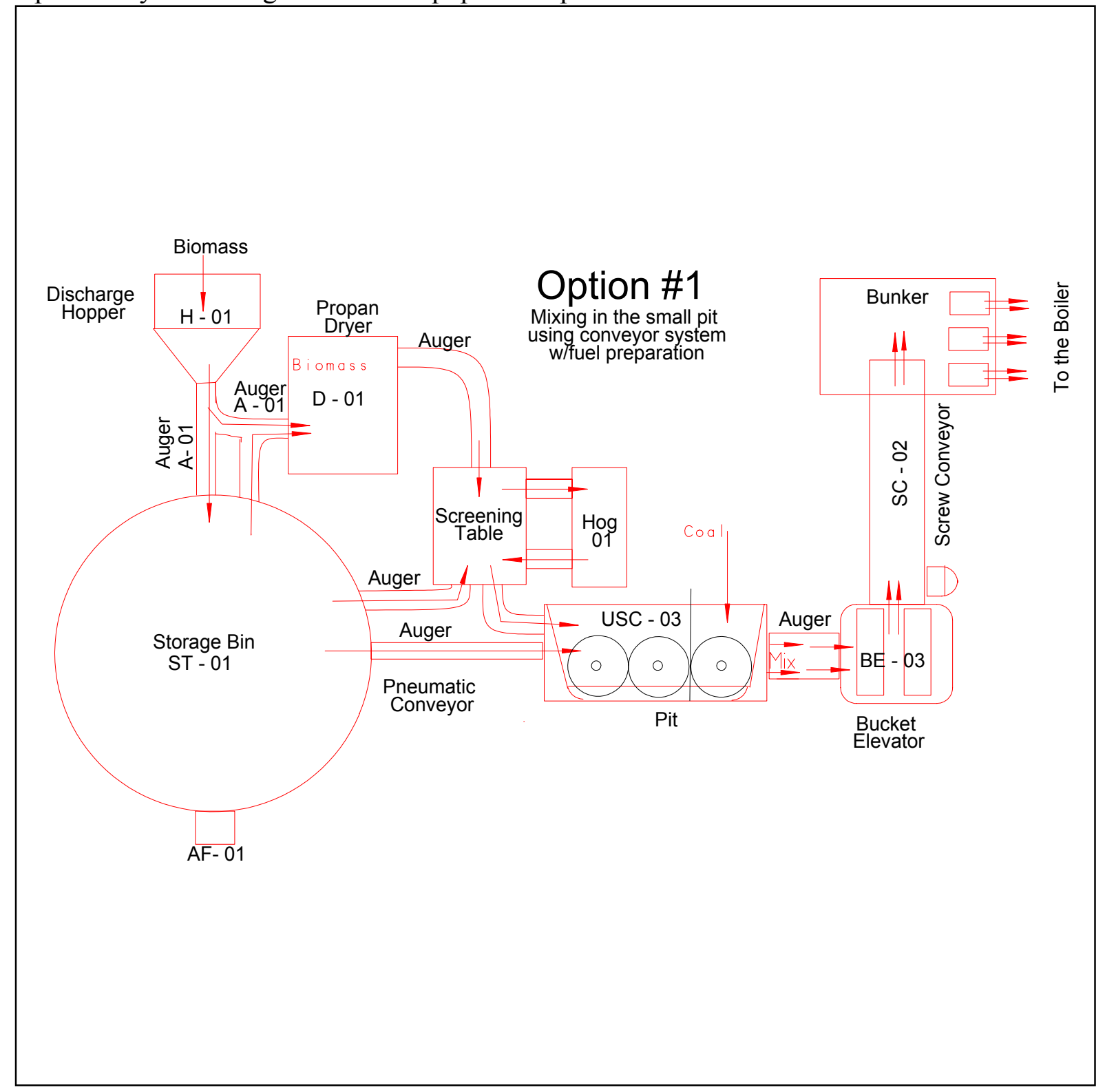


Proposed Layout Configuration for Equipment Option \#4

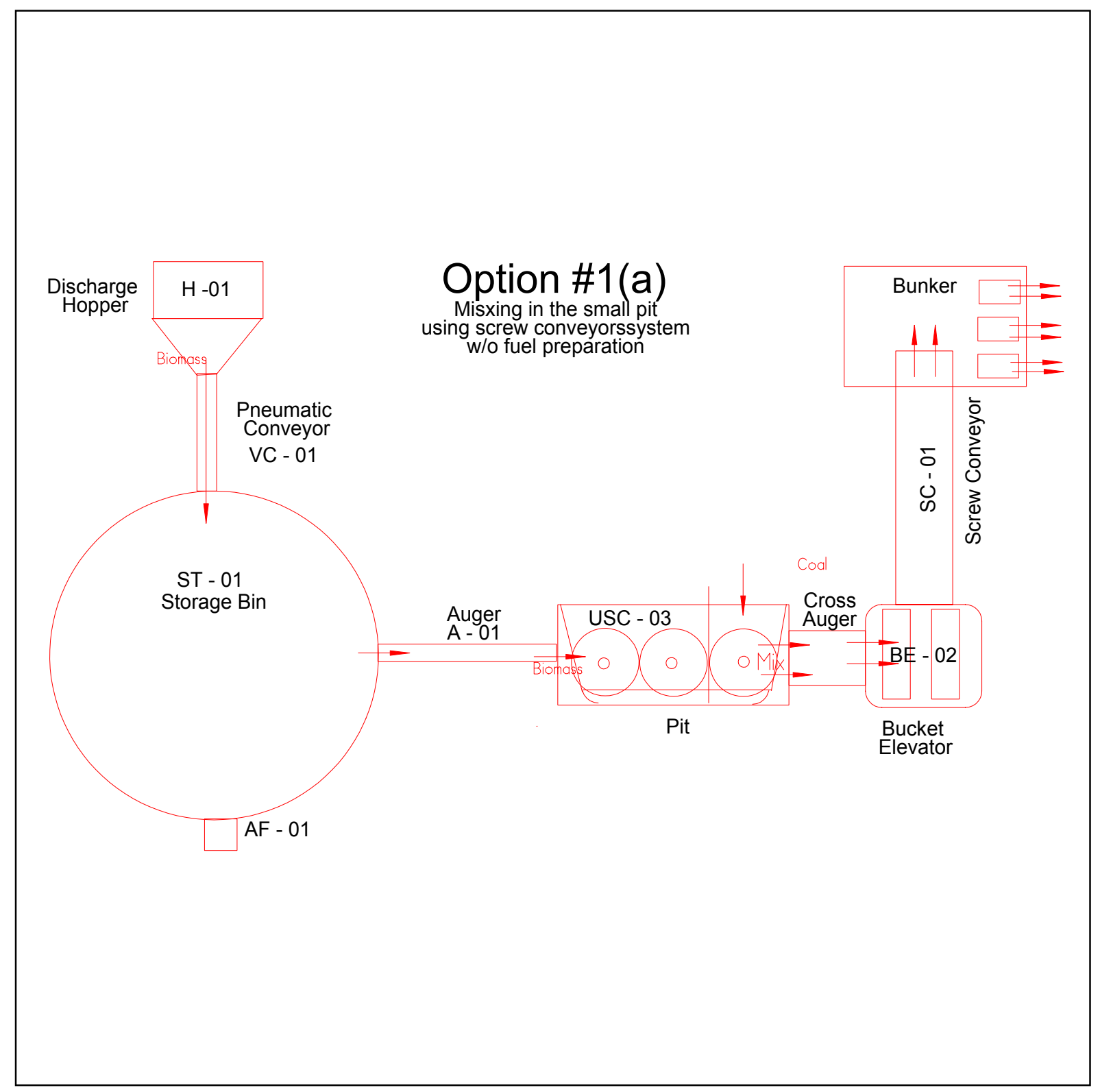




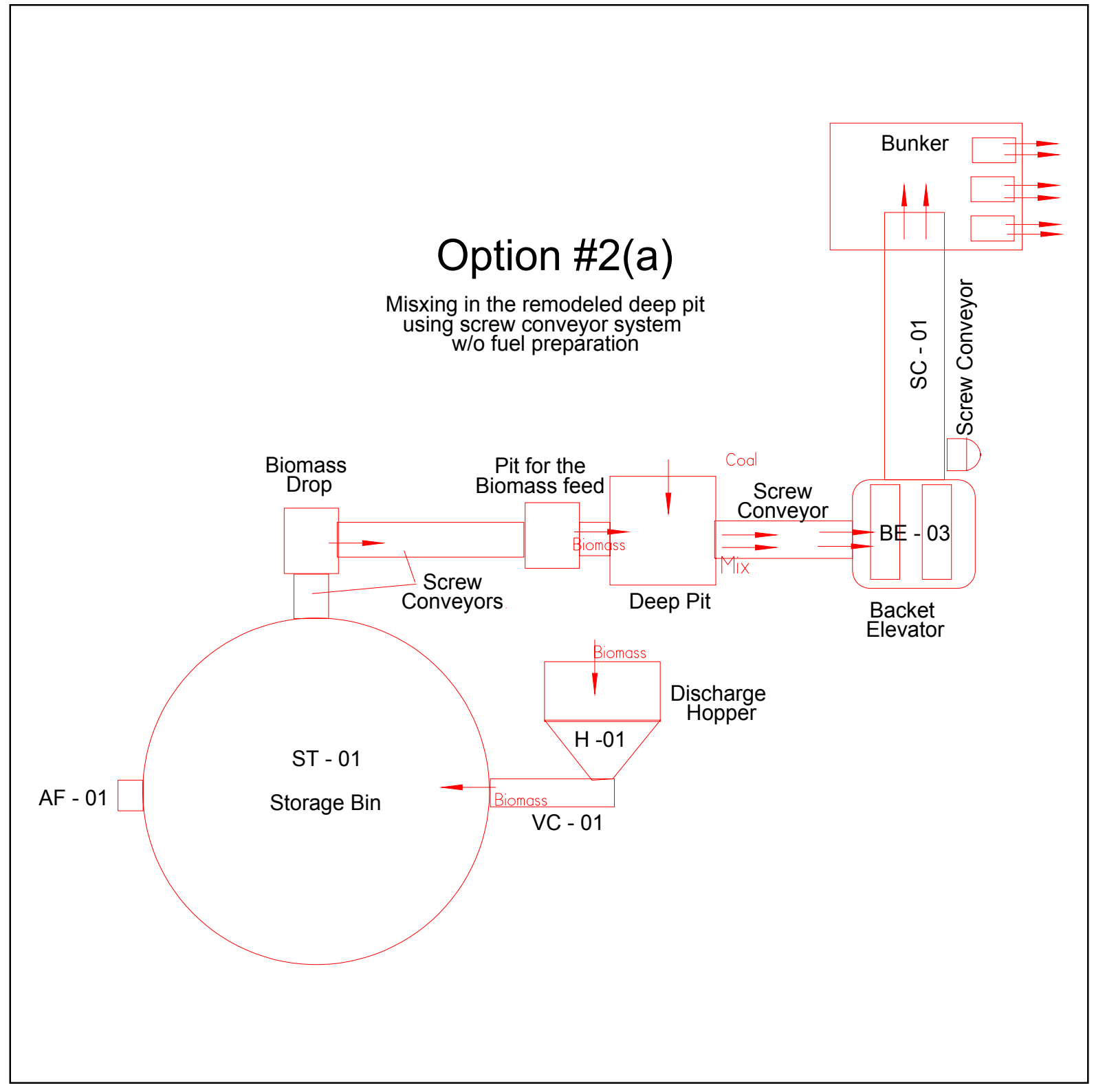




\begin{tabular}{|c|c|c|c|c|c|c|c|c|c|c|c|c|c|c|}
\hline 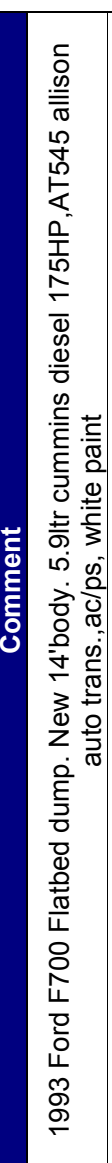 & 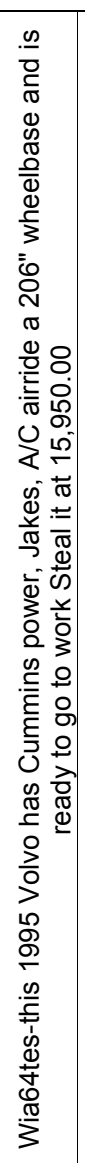 & 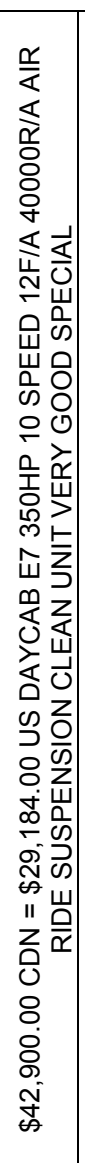 & 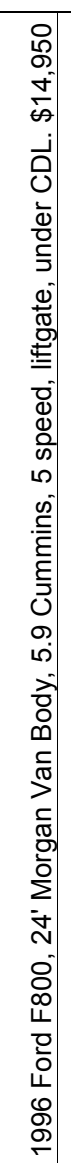 & 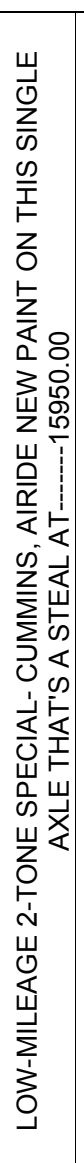 & 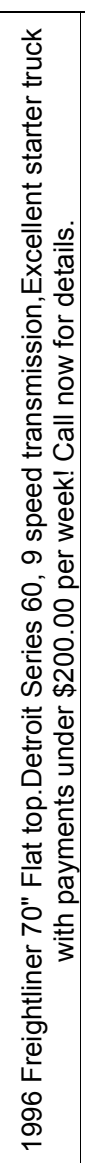 & 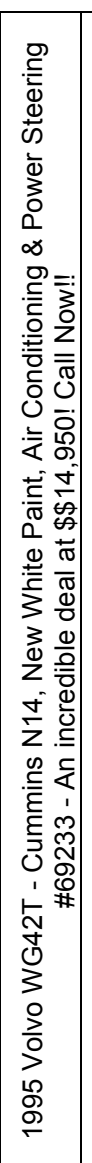 & 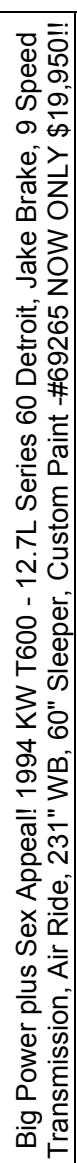 & 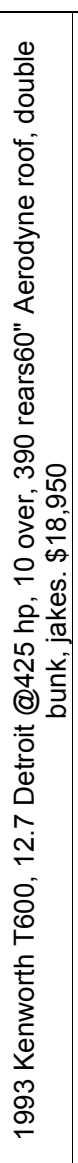 & 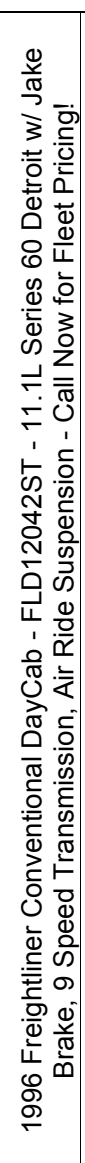 & 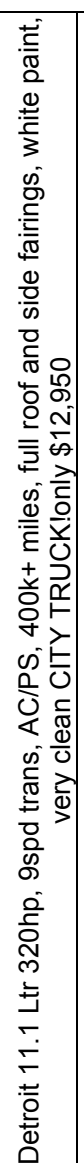 & 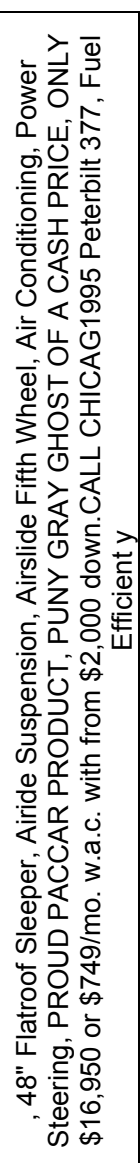 & 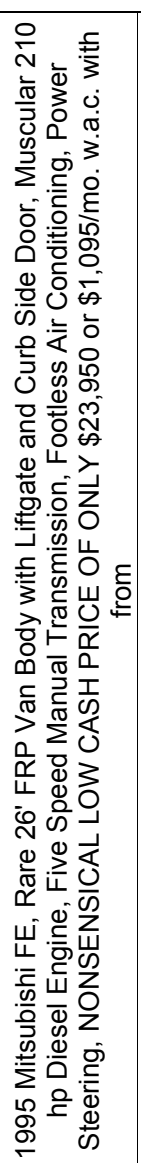 & 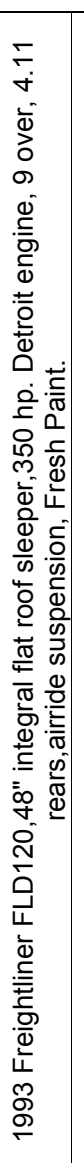 & 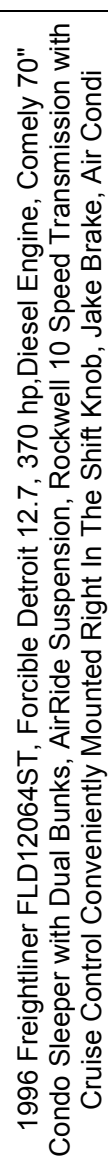 \\
\hline $\begin{array}{l}\bar{o} \\
\tilde{y} \\
\stackrel{J}{\leftarrow}\end{array}$ & 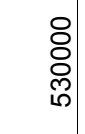 & 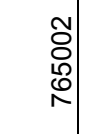 & $\begin{array}{l}\overline{8} \\
\stackrel{\circ}{\circ}\end{array}$ & 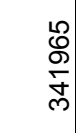 & 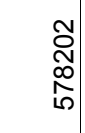 & $\begin{array}{l}\circ \\
0 \\
0 \\
0\end{array}$ & 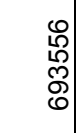 & $\begin{array}{l}\hat{ָ} \\
\bar{\emptyset} \\
\bar{\sigma}\end{array}$ & 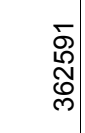 & 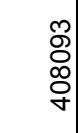 & 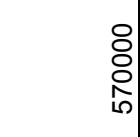 & 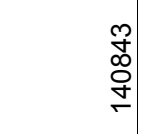 & $\begin{array}{l}+ \\
\infty \\
o \\
o \\
o\end{array}$ & 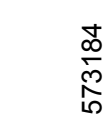 \\
\hline 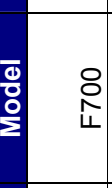 & $\begin{array}{c}0 \\
w \\
5 \\
0 \\
\vdots \\
3\end{array}$ & $\begin{array}{l}\frac{m}{0} \\
\frac{T}{U}\end{array}$ & $\begin{array}{l}0 \\
8 \\
\infty \\
\llcorner\end{array}$ & 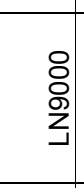 & 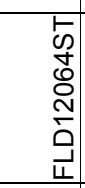 & $\begin{array}{l}5 \\
\mathbb{N} \\
0 \\
3\end{array}$ & \& & $\begin{array}{l}\text { ঃ } \\
\bullet\end{array}$ & 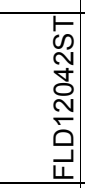 & 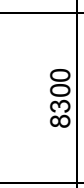 & $\underset{m}{\hat{m}}$ & $\underset{\Psi}{\Psi}$ & $\begin{array}{l}5 \\
c \\
+ \\
0 \\
N \\
\vdots \\
\bar{u}\end{array}$ & 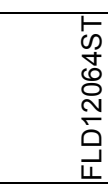 \\
\hline $\begin{array}{l}\mathscr{\Omega} \\
\stackrel{\Omega}{\leftarrow}\end{array}$ & $\begin{array}{l}\stackrel{2}{\circ} \\
\stackrel{\sigma}{\sigma}\end{array}$ & 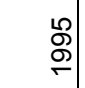 & $\begin{array}{l}\mathscr{Q} \\
\stackrel{2}{\Gamma}\end{array}$ & $\begin{array}{l}\stackrel{\leftrightarrow}{\circ} \\
\stackrel{\sigma}{\circ}\end{array}$ & 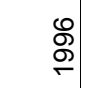 & $\begin{array}{l}\stackrel{\varrho}{\circ} \\
\stackrel{\sigma}{\sigma}\end{array}$ & ঃ্ & $\stackrel{\text { Љ }}{\circ}$ & $\begin{array}{l}\stackrel{8}{\circ} \\
\stackrel{\circ}{-}\end{array}$ & $\stackrel{\overbrace{}}{\mathscr{్}}$ & ஜூ & $\begin{array}{l}\stackrel{\swarrow}{\circ} \\
\stackrel{\sigma}{\sigma}\end{array}$ & $\begin{array}{l}\mathscr{} \\
\stackrel{\sigma}{\sigma}\end{array}$ & ஜ̊ \\
\hline $\begin{array}{l}0 \\
\underline{\alpha} \\
0 \\
4\end{array}$ & $\begin{array}{l}\mathrm{O} \\
\mathrm{D} \\
>\end{array}$ & $\begin{array}{l}\frac{y}{0} \\
\frac{1}{\Sigma}\end{array}$ & 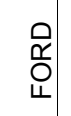 & 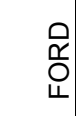 & $\vec{u}$ & $\begin{array}{l}\stackrel{0}{ } \\
\stackrel{1}{>}\end{array}$ & 3 & $\begin{array}{l}3 \\
3\end{array}$ & $\vec{\omega}$ & 呈 & $\begin{array}{l}\stackrel{\mathrm{w}}{\mathrm{w}} \\
\underline{\underline{a}}\end{array}$ & $\begin{array}{l}\supset \\
\stackrel{\rho}{\ominus} \\
\stackrel{5}{\Sigma}\end{array}$ & $\vec{u}$ & $\vec{u}$ \\
\hline 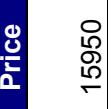 & $\begin{array}{l}0 \\
\stackrel{0}{0} \\
0 \\
\end{array}$ & $\begin{array}{l}\text { : } \\
\stackrel{్}{\text { m}}\end{array}$ & $\begin{array}{l}0 \\
\stackrel{h}{0} \\
\stackrel{\rho}{r}\end{array}$ & $\begin{array}{l}\text { ○ी } \\
\text { ô }\end{array}$ & $\begin{array}{l}\stackrel{\circ}{\circ} \\
\stackrel{\leftrightarrow}{\sim}\end{array}$ & $\begin{array}{l}\stackrel{8}{0} \\
\stackrel{\sigma}{\sigma}\end{array}$ & $\begin{array}{l}\stackrel{0}{\Omega} \\
\stackrel{\sigma}{N}\end{array}$ & $\begin{array}{l}\stackrel{0}{\circ} \\
\stackrel{0}{\sim}\end{array}$ & 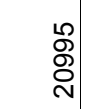 & 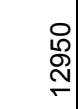 & $\begin{array}{l}0 \\
\text { ஜ̂ } \\
0 \\
0\end{array}$ & $\begin{array}{l}\stackrel{\circ}{\circ} \\
\stackrel{్}{N}\end{array}$ & 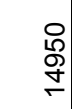 & $\begin{array}{l}\stackrel{8}{8} \\
\text { \& }\end{array}$ \\
\hline 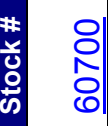 & $\begin{array}{l}\text { ఫે } \\
\text { ల్లి }\end{array}$ & 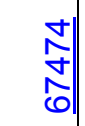 & 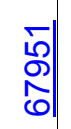 & 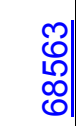 & 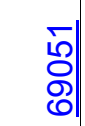 & 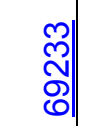 & 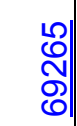 & $\begin{array}{l}\text { गొ| } \\
\text { ळి }\end{array}$ & 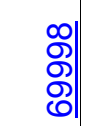 & 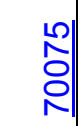 & $\frac{\Omega}{2}$ & $\begin{array}{l}\text { 的 } \\
\text { 인 }\end{array}$ & $\begin{array}{l}N \\
\frac{N}{N} \\
\frac{n}{2}\end{array}$ & $\begin{array}{l}\text { ग) } \\
\frac{0}{n}\end{array}$ \\
\hline
\end{tabular}




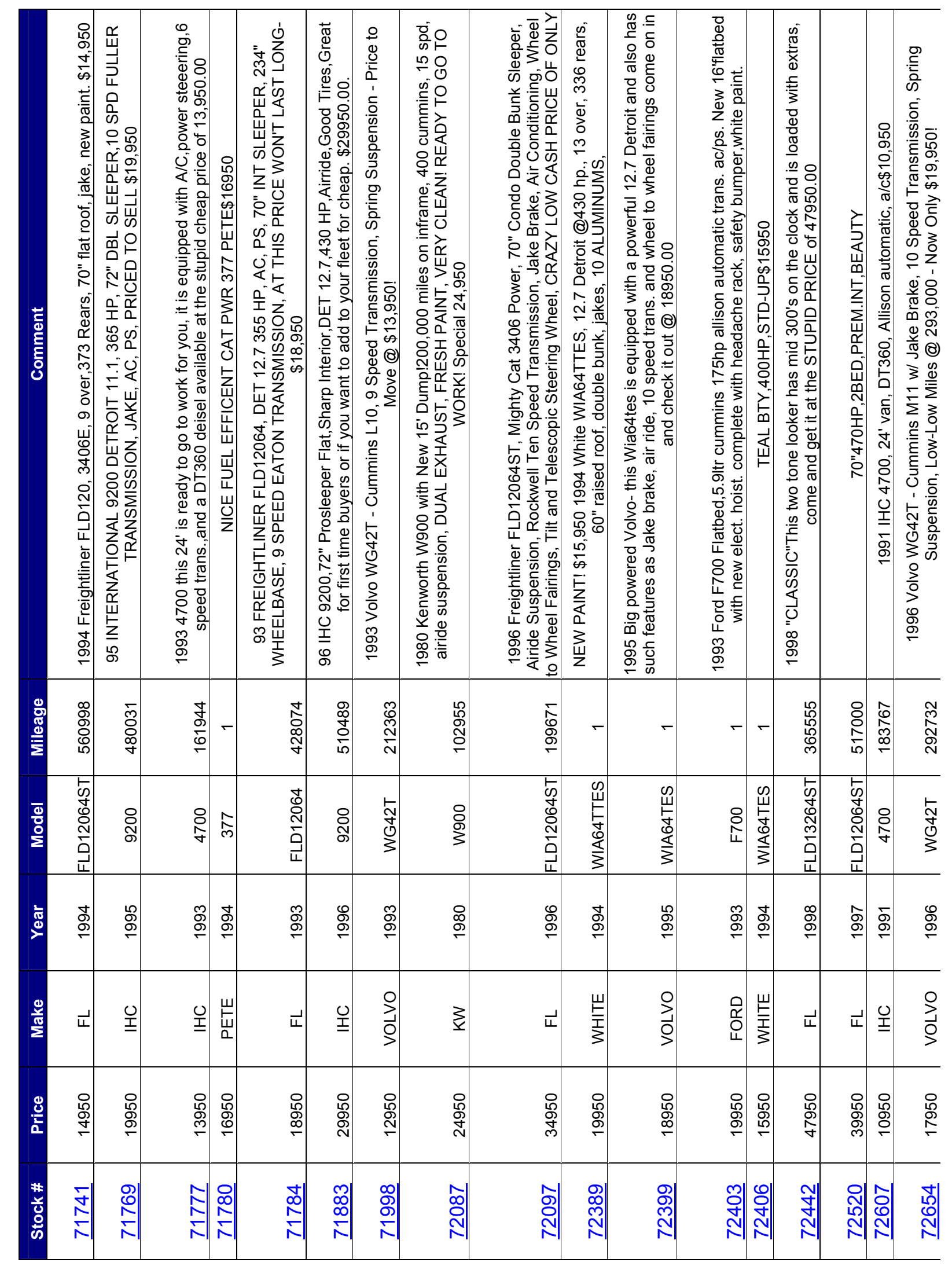




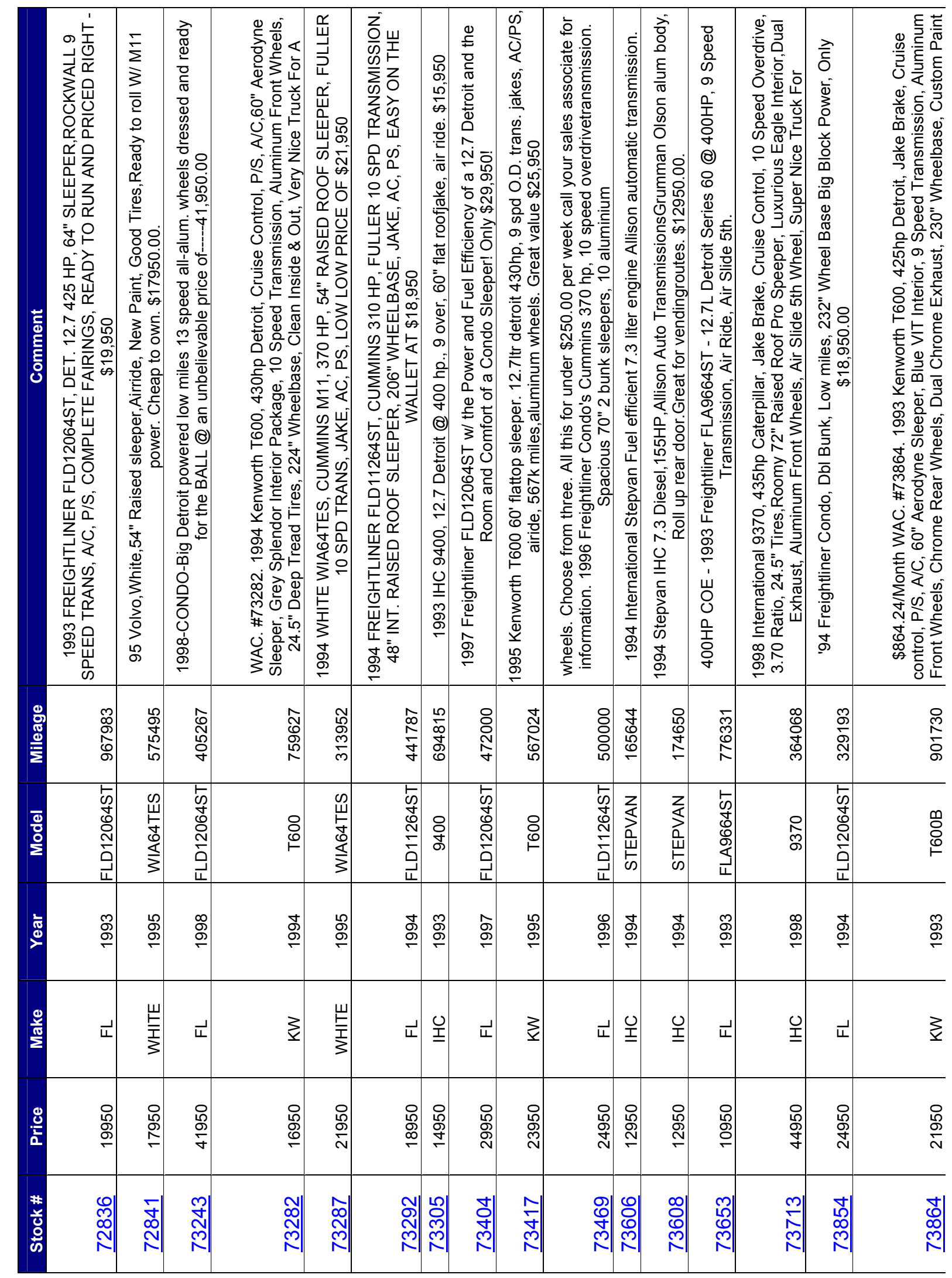




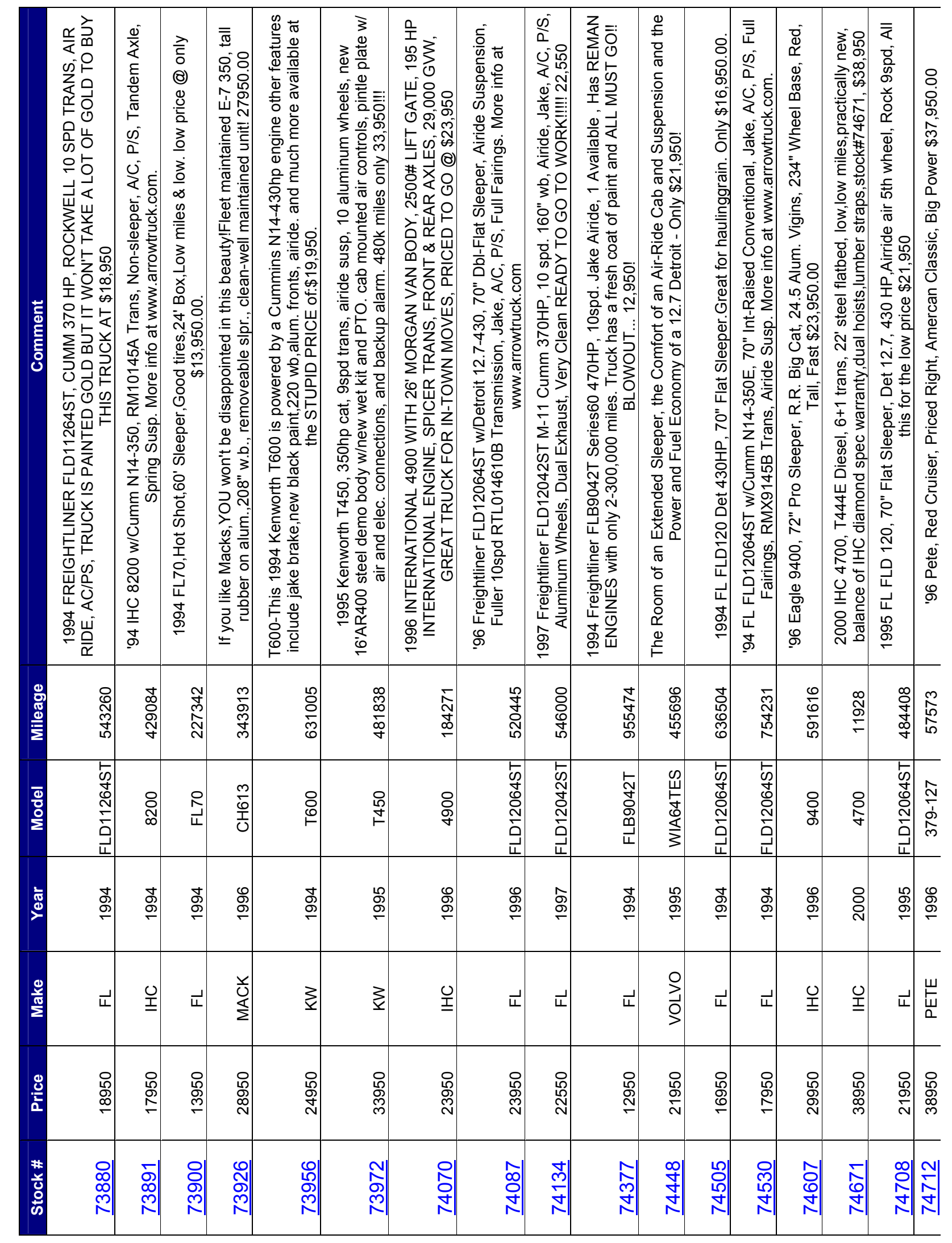




\begin{tabular}{|c|c|c|c|c|c|c|c|c|c|c|c|c|c|c|c|}
\hline 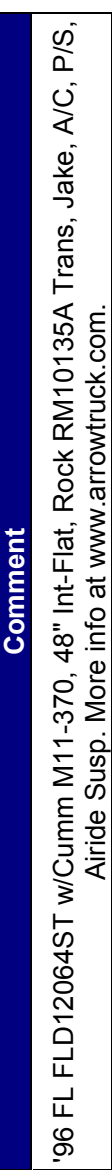 & 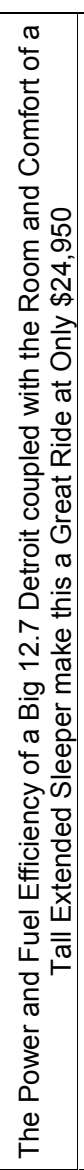 & 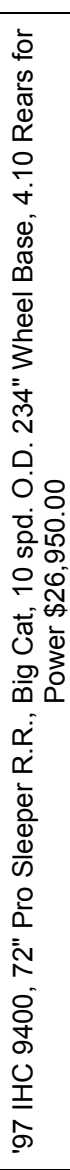 & 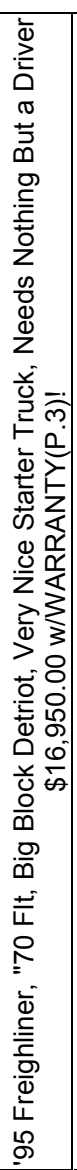 & 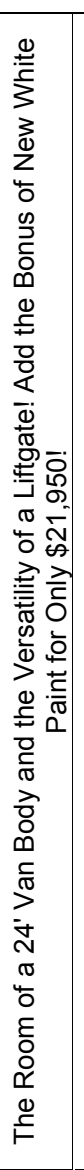 & 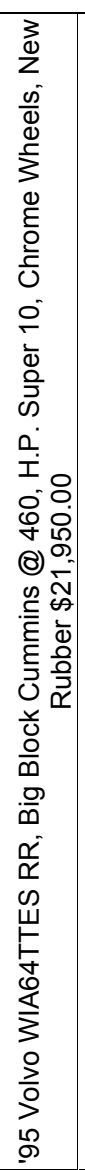 & 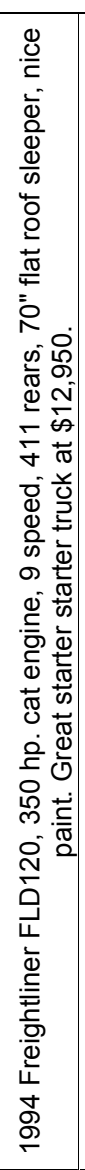 & 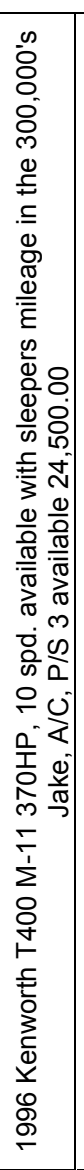 & 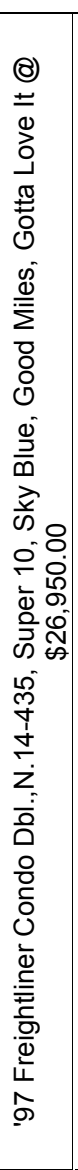 & 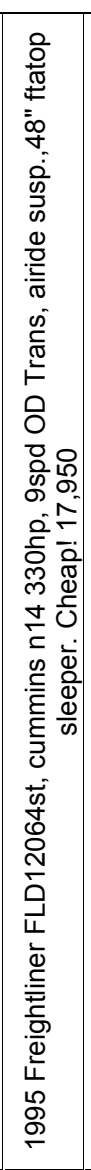 & 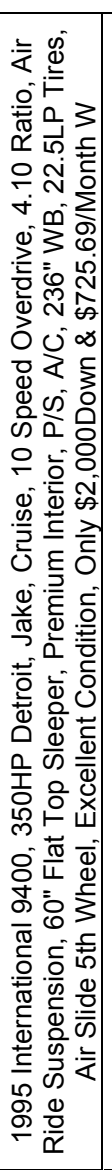 & 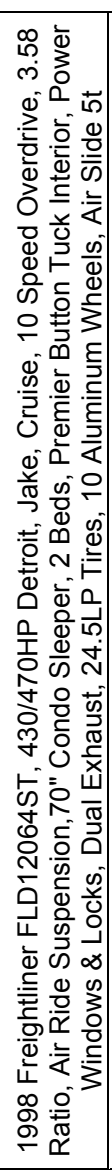 & 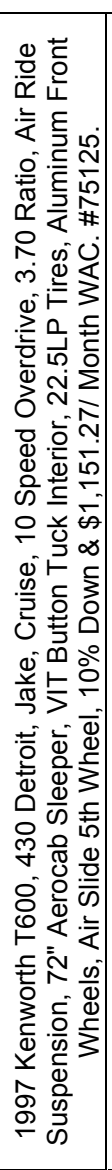 & 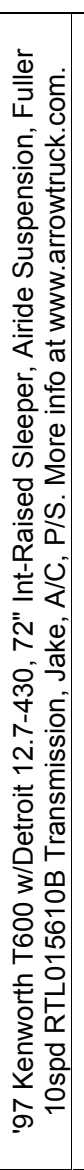 & 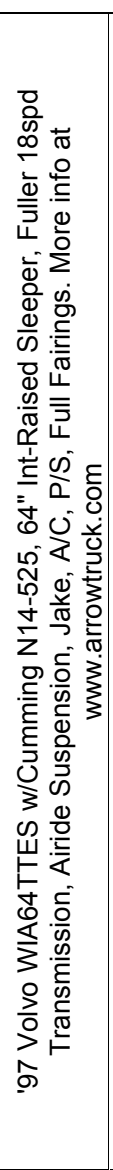 & 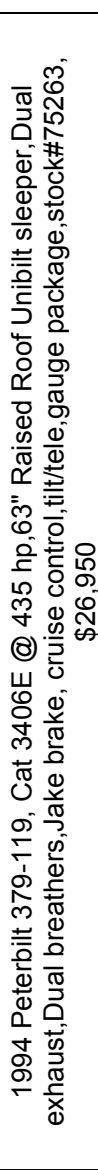 \\
\hline 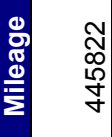 & 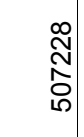 & $\begin{array}{l}\hat{N} \\
\stackrel{8}{\circ} \\
i\end{array}$ & $\begin{array}{l}0 \\
\vdots \\
0 \\
0 \\
0\end{array}$ & $\begin{array}{l}0 \\
\infty \\
\& \\
\mathscr{D} \\
\stackrel{m}{\sim}\end{array}$ & $\begin{array}{l}\text { ㄱ. } \\
\infty \\
o \\
\varnothing \\
\wp\end{array}$ & 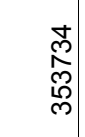 & $\begin{array}{l}\mathbb{N} \\
\stackrel{N}{m} \\
\stackrel{m}{n}\end{array}$ & $\begin{array}{l}0 \\
0 \\
0 \\
0 \\
\vdots \\
ٌ\end{array}$ & 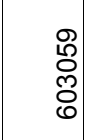 & 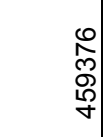 & 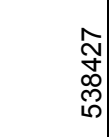 & 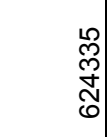 & $\begin{array}{l}\frac{0}{5} \\
5 \\
0 \\
i n\end{array}$ & $\begin{array}{l}8 \\
\vdots \\
\mathbb{N} \\
\end{array}$ & 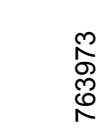 \\
\hline 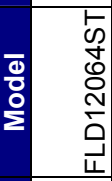 & $\begin{array}{l}c \\
w \\
w \\
5 \\
\vdots \\
0 \\
\vdots \\
3\end{array}$ & $\begin{array}{l}\text { ঃ } \\
\text { ఫे }\end{array}$ & 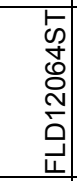 & $\begin{array}{l}\text { ১ } \\
\stackrel{\sigma}{\sigma}\end{array}$ & $\begin{array}{l}c \\
w \\
w \\
5 \\
\vdots \\
\vdots \\
\vdots \\
\vdots\end{array}$ & 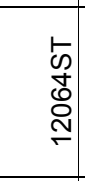 & 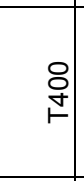 & 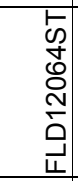 & 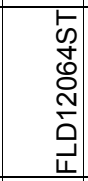 & $\begin{array}{l}\text { ㅇ } \\
\text { ఫे }\end{array}$ & 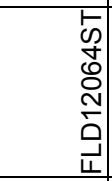 & $\begin{array}{l}\text { : } \\
\bullet\end{array}$ & $\begin{array}{l}\stackrel{0}{\circ} \\
\bullet\end{array}$ & 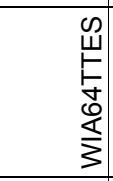 & \\
\hline $\begin{array}{l}\mathscr{⿱} \\
\stackrel{\odot}{\leftarrow}\end{array}$ & $\begin{array}{l}\mathscr{8} \\
\stackrel{\odot}{\odot}\end{array}$ & 용 & 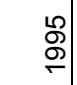 & $\begin{array}{l}\mathscr{O} \\
\stackrel{\circ}{\Gamma}\end{array}$ & $\begin{array}{l}\llcorner\mathscr{\Omega} \\
\stackrel{\circ}{\Gamma}\end{array}$ & 志 & $\begin{array}{l}\mathscr{\varrho} \\
\stackrel{\circ}{\Gamma}\end{array}$ & ్요 & 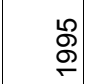 & 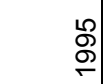 & 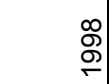 & ్ㅇㅇ & 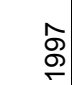 & 今. & 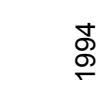 \\
\hline$\vec{\amalg}$ & $\begin{array}{l}\mathrm{O} \\
\stackrel{3}{\mathrm{O}}\end{array}$ & 呈 & $\vec{\omega}$ & 呈 & $\begin{array}{l}\mathrm{O} \\
\stackrel{3}{\mathrm{O}} \\
\mathrm{P}\end{array}$ & $\vec{\Psi}$ & $\begin{array}{l}3 \\
3\end{array}$ & $\vec{\omega}$ & $\vec{\omega}$ & 呈 & $\vec{\Psi}$ & $\begin{array}{l}3 \\
\mathbf{1}\end{array}$ & $\begin{array}{l}3 \\
3\end{array}$ & $\begin{array}{l}\rho \\
\stackrel{\partial}{\rho} \\
\end{array}$ & 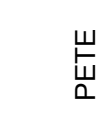 \\
\hline $\begin{array}{l}\text { ஜू } \\
\stackrel{\infty}{\circ}\end{array}$ & $\begin{array}{l}0 \\
\stackrel{\leftrightarrow}{+} \\
\stackrel{2}{2}\end{array}$ & $\begin{array}{l}\text { \&్ } \\
\text { న్లి }\end{array}$ & $\begin{array}{l}\text { : } \\
\text { N̦ } \\
\text { ans }\end{array}$ & $\begin{array}{l}\frac{0}{2} \\
\stackrel{\circ}{N}\end{array}$ & $\begin{array}{l}\stackrel{\circ}{\circ} \\
\stackrel{2}{N}\end{array}$ & $\begin{array}{l}\stackrel{\circ}{\circ} \\
\stackrel{m}{\sigma}\end{array}$ & $\begin{array}{l}8 \\
\stackrel{b}{N} \\
\text { no }\end{array}$ & 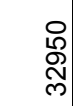 & $\begin{array}{l}0 \\
\stackrel{\leftrightarrow}{0} \\
\stackrel{0}{0}\end{array}$ & $\begin{array}{l}0 \\
\stackrel{\circ}{2} \\
\stackrel{2}{\sim}\end{array}$ & 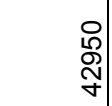 & 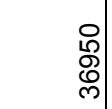 & 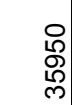 & $\begin{array}{l}0 \\
\stackrel{0}{\rho} \\
\frac{\rho}{m}\end{array}$ & $\begin{array}{l}\text { \&్ } \\
\text { \& } \\
\text { N. }\end{array}$ \\
\hline$\underset{⿱}{ \pm}$ & $\begin{array}{l}\text { 足 } \\
\text { 守 }\end{array}$ & 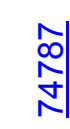 & 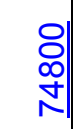 & $\begin{array}{l}\text { 이 } \\
\infty \\
\text { ㄴ| }\end{array}$ & \begin{tabular}{l|l} 
요 & ô \\
ㄱ.
\end{tabular} & $\begin{array}{l}\text { 号 } \\
\text { N }\end{array}$ & 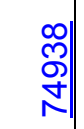 & 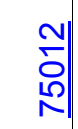 & 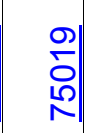 & 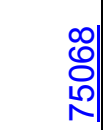 & 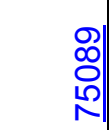 & $\stackrel{\stackrel{2}{n}}{\stackrel{5}{n}}$ & $\begin{array}{l}\stackrel{\varrho}{N} \\
\frac{1}{N}\end{array}$ & $\begin{array}{l}\text { Oे } \\
\text { N్} \\
\stackrel{n}{N}\end{array}$ & $\begin{array}{l}\text { అొ } \\
\text { N్} \\
\end{array}$ \\
\hline
\end{tabular}




\begin{tabular}{|c|c|c|c|c|c|c|c|c|c|c|c|c|c|c|}
\hline 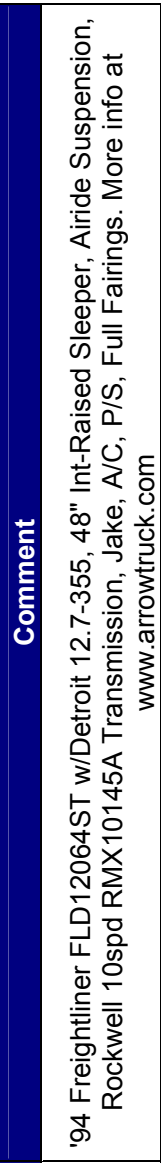 & 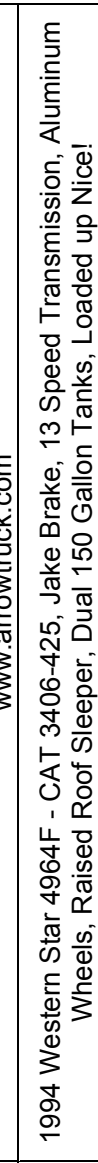 & 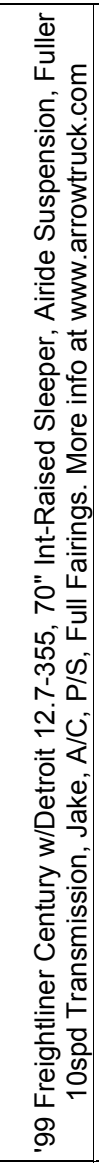 & 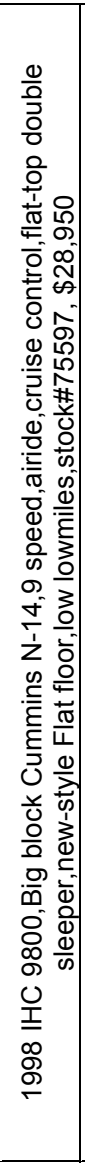 & 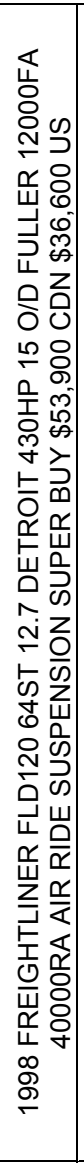 & 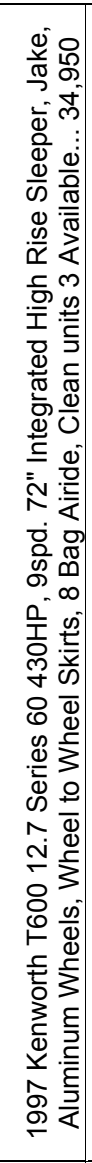 & 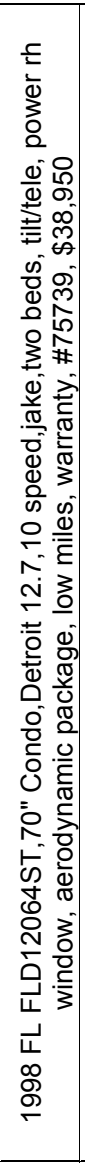 & 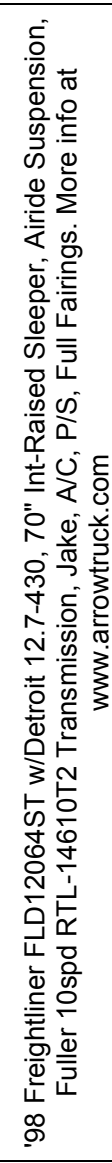 & 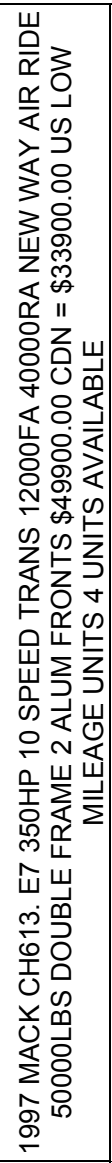 & 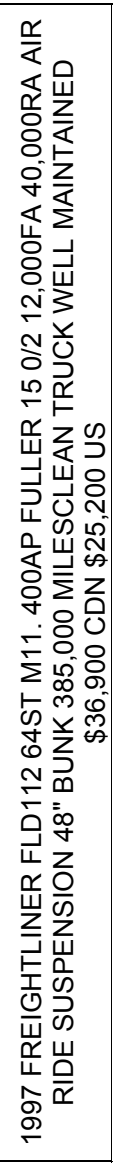 & 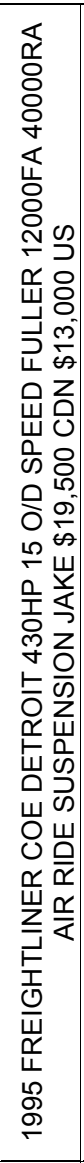 & 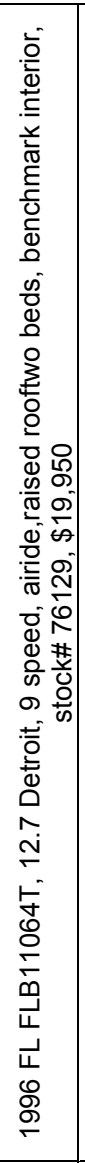 & 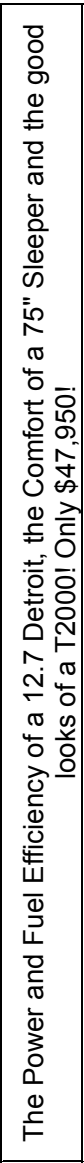 & 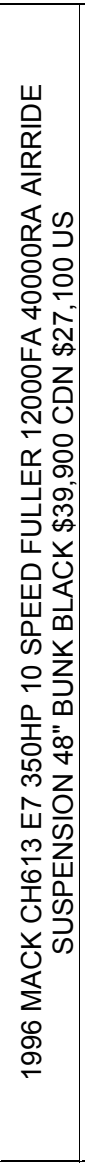 & 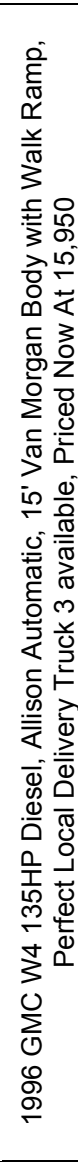 \\
\hline 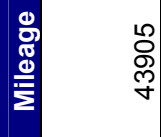 & $\begin{array}{l}\infty \\
\stackrel{2}{5} \\
\infty \\
\stackrel{2}{n}\end{array}$ & 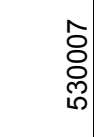 & $\begin{array}{l}\bar{m} \\
\bar{m} \\
\bar{m}\end{array}$ & 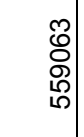 & 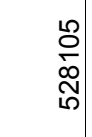 & $\begin{array}{l}8 \\
\vdots \\
\vdots \\
\vdots\end{array}$ & \begin{tabular}{l}
8 \\
$\varnothing$ \\
$\stackrel{0}{f}$ \\
\multirow{f}{*}{}
\end{tabular} & 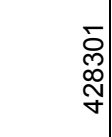 & $\begin{array}{l}\infty \\
\text { ర్ } \\
\text { ర్ర }\end{array}$ & 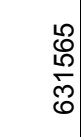 & 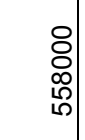 & 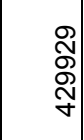 & $\begin{array}{l}\bar{c} \\
\tilde{\sigma} \\
\hat{\sigma}\end{array}$ & \\
\hline 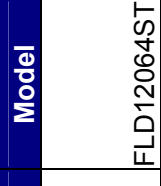 & 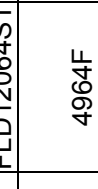 & 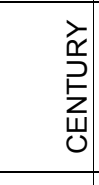 & $\begin{array}{l}\text { ঃे } \\
\text { ه }\end{array}$ & 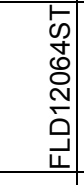 & $\stackrel{8}{\circ}$ & $\begin{array}{l}5 \\
5 \\
5 \\
0 \\
N \\
\vdots \\
\vdots \\
\end{array}$ & on & $\begin{array}{l}\frac{m}{\vdots} \\
\frac{1}{0} \\
0\end{array}$ & $\begin{array}{c}N \\
\\
\end{array}$ & $\begin{array}{l}\text { 志 } \\
\& \\
\infty\end{array}$ & 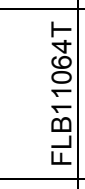 & 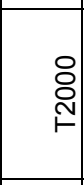 & $\begin{array}{l}m \\
\frac{0}{0} \\
\frac{1}{v}\end{array}$ & $\stackrel{ \pm}{3}$ \\
\hline $\begin{array}{l}\stackrel{\leftrightarrow}{\circ} \\
\stackrel{\circ}{\sigma}\end{array}$ & 옹 & $\begin{array}{l}\text { \& } \\
\stackrel{8}{\circ}\end{array}$ & 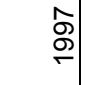 & $\begin{array}{l}\infty \\
\stackrel{\infty}{\leftarrow} \\
\end{array}$ & Љ্ & 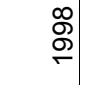 & $\stackrel{\text { }}{\stackrel{2}{2}}$ & $\stackrel{\text { }}{\circ}$ & $\begin{array}{l}\text { Фे } \\
\stackrel{\sigma}{\circ}\end{array}$ & 导 & 足 & $\begin{array}{l}\infty \\
\stackrel{\odot}{-}\end{array}$ & $\begin{array}{l}\mathscr{\mathscr { D }} \\
\stackrel{\circ}{\sigma}\end{array}$ & 禺 \\
\hline$\vec{u}$ & $\begin{array}{l}\frac{a}{5} \\
\frac{5}{3} \\
3\end{array}$ & $\vec{\sqcup}$ & 옾 & $\vec{山}$ & $\frac{3}{3}$ & $\vec{\psi}$ & $\vec{\uplus}$ & $\overline{\bar{d}}$ & $\vec{\sqcup}$ & $\vec{\uplus}$ & $\vec{\uplus}$ & 3 & $\begin{array}{l}\frac{\gamma}{0} \\
\frac{1}{\Sigma}\end{array}$ & $\sum_{0}^{0}$ \\
\hline $\begin{array}{l}\text { ధ్ } \\
\text { ద్ }\end{array}$ & 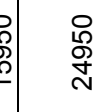 & \begin{tabular}{l}
$\circ$ \\
$\stackrel{o}{2}$ \\
\multirow{f}{*}{}
\end{tabular} & $\begin{array}{l}\text { P. } \\
\stackrel{8}{\$} \\
\text { N }\end{array}$ & ষ্ণী & 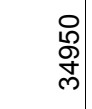 & 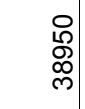 & 。্ & $\begin{array}{l}\text { ठ্ } \\
\stackrel{Ð}{\checkmark}\end{array}$ & $\begin{array}{l}\text { : } \\
\text { ठ } \\
\text { d }\end{array}$ & $\begin{array}{l}\text { \& } \\
\text { 욤 }\end{array}$ & $\begin{array}{l}\text { ஜ̊ } \\
\text { ᄋ }\end{array}$ & \begin{tabular}{l}
$\circ$ \\
$\stackrel{o}{o}$ \\
\multirow{y}{*}{}
\end{tabular} & $\begin{array}{l}\text { ঃ } \\
\text { ্ল }\end{array}$ & 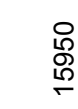 \\
\hline 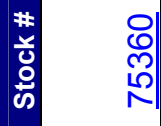 & $\begin{array}{l}\infty \\
\\
\\
N\end{array}$ & 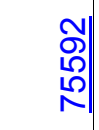 & $\begin{array}{l}\hat{D} \\
\hat{n} \\
\hat{n}\end{array}$ & $\begin{array}{l}\mathrm{N} \\
\stackrel{0}{h} \\
\stackrel{h}{N}\end{array}$ & $\begin{array}{l}\forall \\
0 \\
\stackrel{n}{N}\end{array}$ & $\begin{array}{l}\text { న } \\
\stackrel{n}{N}\end{array}$ & $\frac{\mathbb{N}}{n}$ & 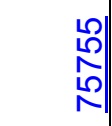 & $\begin{array}{l}\text { లి } \\
\text { مొ } \\
\end{array}$ & $\begin{array}{l}\infty \\
\hat{\circ} \\
\stackrel{1}{\Lambda}\end{array}$ & $\begin{array}{l}\mathrm{N} \\
\frac{\mathrm{N}}{N}\end{array}$ & $\begin{array}{l}\infty \\
m \\
\vdots \\
\end{array}$ & $\begin{array}{l}\infty \\
\frac{\infty}{1} \\
N\end{array}$ & $\begin{array}{l}\underset{N}{0} \\
\text { }\end{array}$ \\
\hline
\end{tabular}

